Milton Thiago Guerino Silva

Avaliação de potencial agente vacinal contra o $s$. pyogenes em camundongos transgênicos, portadores de genes HLA de classe II humanos

Dissertação apresentada à Faculdade de Medicina da Universidade de São Paulo para a obtenção do título de Mestre em Ciências

Programa de Alergia e Imunopatologia

Orientadora: Prof ${ }^{\mathrm{a}}$. Dr ${ }^{\mathrm{a}}$ Luiza Guilherme Guglielmi

São Paulo 
Milton Thiago Guerino Silva

Avaliação de potencial agente vacinal contra o $s$. pyogenes em camundongos transgênicos, portadores de genes HLA de classe II humanos

Dissertação apresentada à Faculdade de Medicina da Universidade de São Paulo para a obtenção do título de Mestre em Ciências

Programa de Alergia e Imunopatologia

Orientadora: Prof ${ }^{\mathrm{a}}$. Dr ${ }^{\mathrm{a}}$ Luiza Guilherme Guglielmi

Versão Corrigida

São Paulo

2011 
Dados Internacionais de Catalogação na Publicação (CIP)

Preparada pela Biblioteca da

Faculdade de Medicina da Universidade de São Paulo

Creprodução autorizada pelo autor

Guerino-Silva, Milton Thiago

Avaliação de potencial agente vacinal contra o $S$. pyogenes em camundongos transgênicos, portadores de genes HLA de classe II humanos / Milton Thiago Guerino Silva. -- São Paulo, 2011.

Dissertação(mestrado)--Faculdade de Medicina da Universidade de São Paulo. Programa de Alergia e Imunopatologia.

Orientadora: Luiza Guilherme Guglielmi.

Descritores: 1.Vacinas estreptocócicas 2.Camundongos transgênicos 3.Genes classe II do complexo de histocompatibilidade (MHC) 4.Imunidade humoral 5.Imunidade celular

USP/FM/DBD-270/11 
A meu pai, quem me ensinou o valor e a satisfação em promover a saúde daqueles que mais necessitam. O maior entusiasta de minhas conquistas que não pode ver a finalização deste trabalho. 


\section{Agradecimentos}

À minha mãe, por toda demonstração de força e amor à vida para permanecer ao meu lado, oferecendo todo tipo de suporte e incentivo para superar as adversidades em meu caminho;

Ao meu irmão que sempre me ajudou nas mais complexas situações e me faz ver a vida de maneira singular;

À minha orientadora Luiza Guglielmi, pela oportunidade da realização desse projeto junto ao grupo de Febre Reumática, assim como todo incentivo, motivação, direcionamento e ajuda dispensada;

Ao grande amigo Edilberto Postól, que me auxiliou durante todo o desenvolvimento deste trabalho e foi o responsável pelo meu amadurecimento profissional e científico;

Ao Professor Jorge Kalil, por todos os ensinamentos e atenção dedicada em nossas reuniões;

À Léa Maria Macruz Ferreira Demarchi do Laboratório de Anatomia Patológica do Instituto do Coração, pelas avaliações histopatológicas realizadas e ajuda no desenvolvimento desse trabalho;

Aos amigos de bancada e excelentes profissionais que contribuíram diretamente para a realização desse trabalho: Fábio Higa, Luiz Mündel, Raquel 
Alencar, Samar Freschi, Daniela Rosa, Susan Ribeiro, Rafael Ribeiro e José Carlos Santos, por todo apoio, paciência, incentivo e ensinamentos que tornaram a rotina e o meu aprendizado espontâneo, descontraído e gratificante;

Ao grupo de Febre Reumática do Laboratório de Imunologia do Instituto do Coração: Fernanda Alegria, Karine de Amicis, Karen Kohler, kelen Faé, Simone Santos, Iolanda Oruê, Sandra Emiko Oshiro, Selma Palácios, Cláudio Puschel e Washington Silva;

Aos meus amigos do setor de Histocompatibilidade e Imunogenética do Laboratório de Imunologia do InCor: Germano Preuhs, Carlos Vigiani, Andréia Kiyamu, Fernanda Jobim, Olga Morita, Isabel Mota, Carla Ronda, Célia Yamaguti, Sandra Costa, Marcelo Barrocal, Ivete Ramos , Luiz Inácio , Claúdia Rosales, Carol Borba, Filipi Marks, Jonas Klein, Karine Blanez, Claudinéia Souza, Suellen Estrada, Nicolas Panajotopoulos e Hélcio Rodrigues;

A todos os amigos e colegas de laboratório (LIM60 e LIM19) que direta ou indiretamente contribuíram para o desenvolvimento deste trabalho, sempre foram solícitos em me ajudar e incentivar nos momentos mais difíceis

Ao Instituto do Coração do Hospital das Clínicas da Faculdade de São Paulo;

À Coordenação de Aperfeiçoamento de Pessoal de Nível Superior (CAPES). 
Esta dissertaçăo está de acordo com as seguintes normas, em vigor no momento desta publicação

\section{Referências:}

Adaptado de Uniform Requirements for Manuscripts Submitted to Biomedical Joumals, International Committee of Medical Journals Editors (Vancouver).

Universidade de Sāo Paulo. Faculdade de Medicina. Serviço de Biblioteca e Documentaçāo. Guia de apresentaçāo de dissertaçōes, teses e monografias. Elaborado por Carneiro da Cunha, A. et al. 2a ed. Sāo Paulo: Serviço de Biblioteca e Documentação; 2005.

Abreviaturas dos títulos dos periódicos:

List of Journals Indexed in Index Medicus. 


\section{Sumário}

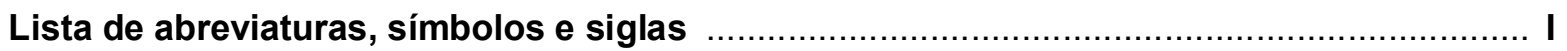

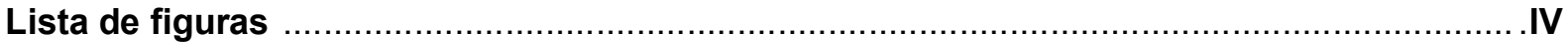

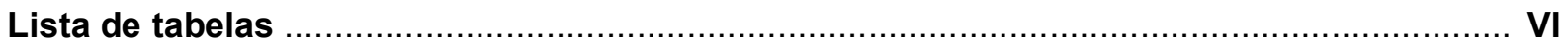

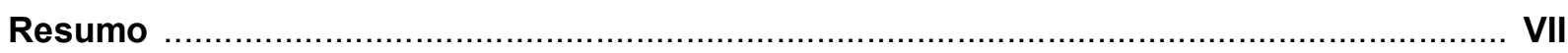

Abstract

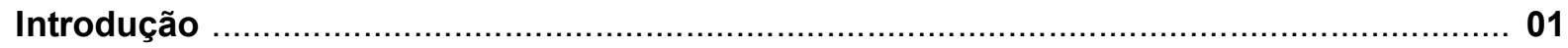

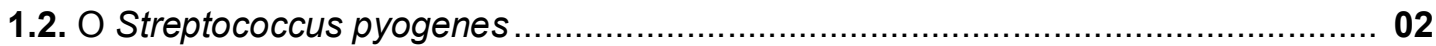

1.3. Doenças desencadeadas pelo S. pyogenes ................................................... 03

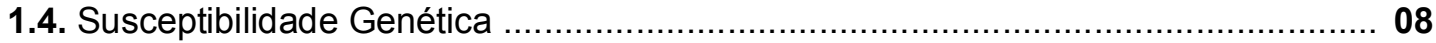

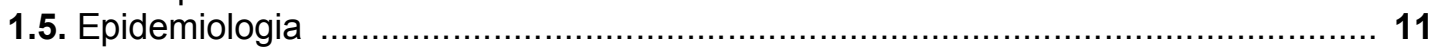

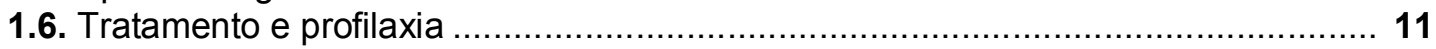

1.7. O Peptídeo Vacinal Sintético StreptInCor ....................................................... 15

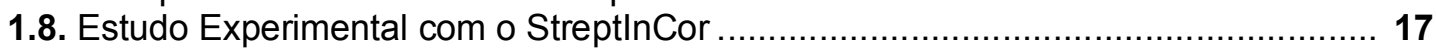

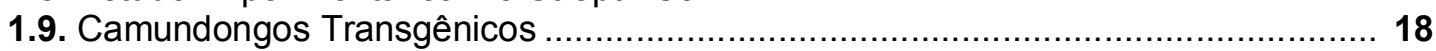

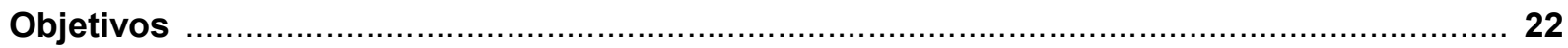

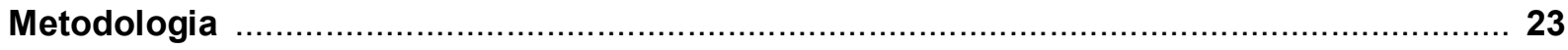

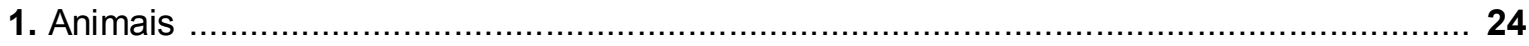

2. Validação de transgenia para o gene HLA de classe II humano em camundongos ........... 24

2.1. Coleta de amostras e obtenção de DNA para as tipificações ................................ 24

2.2. Amplificação de transgene pelo método de PCR-SSP ........................................ 26

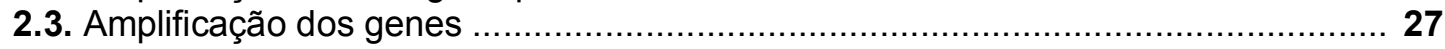

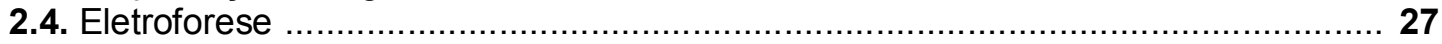

3. Avaliação da expressão de moléculas de HLA de classe II........................................... 28

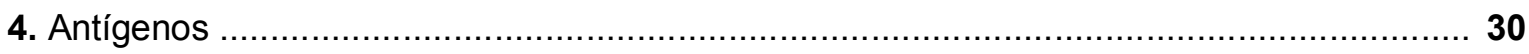

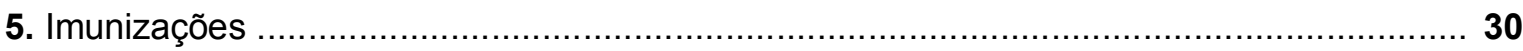

5.1. Imunizações com hidróxido de alumínio ......................................................... 31

5.2. Imunizações com adjuvante de Freund ...................................................... 32

6. Avaliação da resposta imune humoral por ELISA .................................................... 32

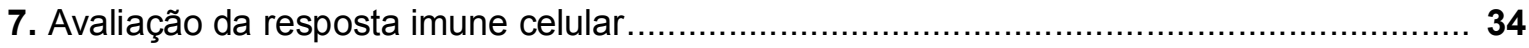

7.1. Obtenção de células mononucleares de camundongos ................................... 34

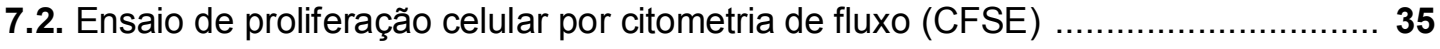

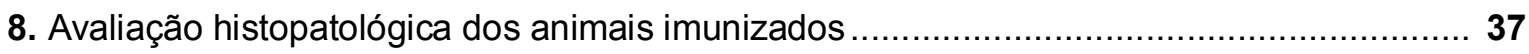

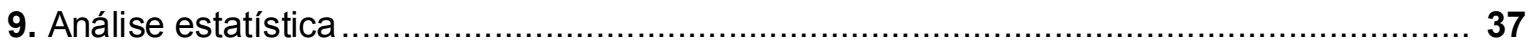




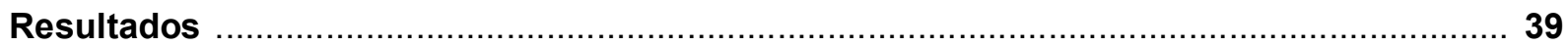

1. Validação de transgenia para o gene HLA de classe II humano em camundongos ........... 40

2. Controle da expressão protéica das moléculas HLA e ausência das moléculas $H-2$ de classe II na superfície celular ............................................................................ 41

3. Análise de expressão de MHC-II murino (IA/IE) por citometria de fluxo ......................... 44

4. Resposta humoral dos camundongos imunizados com o agente vacinal e controles ao

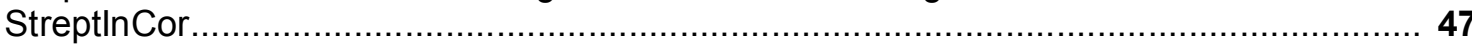

5. Avaliação da durabilidade da resposta imune humoral .............................................. 48

6. Avaliação da produção de subclasses de imunoglobulinas geradas após a imunização

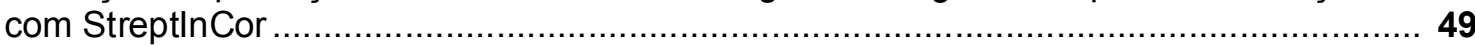

7. Avaliação da resposta humoral à proteína M1 e miosina cardíaca................................... 50

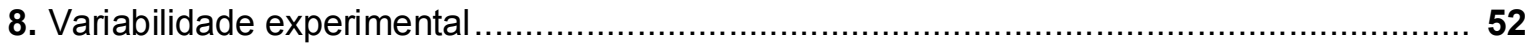

9. Expressão da molécula HLA X resposta humoral ...................................................... 53

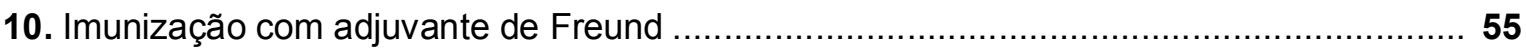

11. Comparação entre imunizações com StreptInCor e Ovalbumina .................................... 56

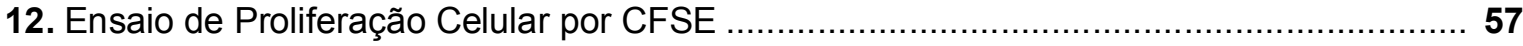

13. Padrão Celular de Memória Após a Proliferação........................................................ 59

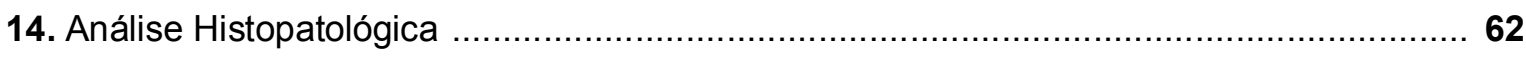

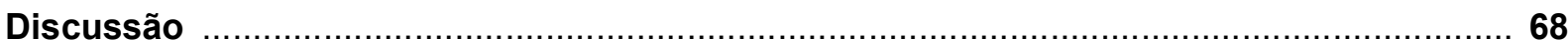

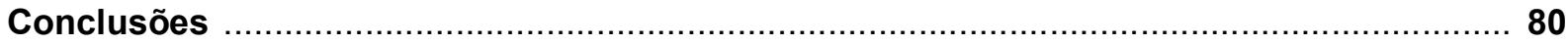

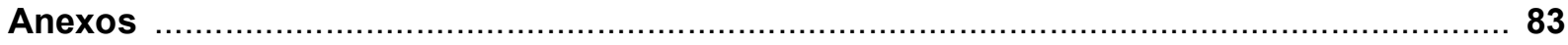

2. Anexo A - Aprovação do Comitê de Ética IMT-SP .......................................................... 84

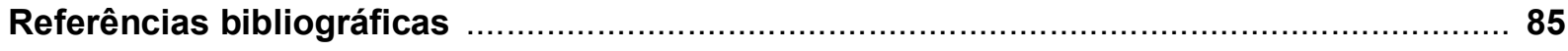

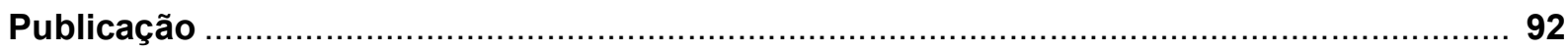




\section{LISTA DE ABREVIATURAS, SÍMBOLOS E SIGLAS}

ACF Adjuvante completo de freund

AIF Adjuvante incompleto de freund

$\mathrm{Al}(\mathrm{OH})_{3} \quad$ Hidróxido de alumínio

APC Allophycocyanin (aloficocianina)

APC Antigen presenting cells (células apresentadoras de antígenos)

BD Benton Dicson

BSA Bovine serum albumin (albumina bovina sérica)

CD Cluster of differentiation (designação de grupos)

CFSE Carboxyfluorescein succinimidyl ester (carboxifluoresceína succinimidil éster)

CFu Colony-forming unit (unidade formadora de colônia)

CO2 Dióxido de carbono

ConA Concanavalina A

CTB Cholera toxin subunit B (subunidade da toxina colérica)

DO Densidade óptica

DM-1 Diabetes mellitus tipo 1

DMSO Dimetil-sulfóxido

DNA deoxyribonucleic acid (Ácido desoxirribonucléico)

dNTP deoxynucleotide triphosphates (deoxinucleotideos trifosfatados)

DRC Doença reumática cardíaca

EDTA Ethylenediamine tetraacetic acid (ácido tetracético etilenodiamínico)

ELISA Enzyme-linked immunosorbent assay (Ensaio imunoenzimático)

et al. e outros

EUA Estados Unidos da América

FITC Isoticianato de fluoresceína 


\begin{tabular}{|c|c|}
\hline FR & Febre Reumática \\
\hline FSC & Forward scatter \\
\hline$g$ & Gramas \\
\hline g & Aceleração da graviadade \\
\hline $\mathrm{HE}$ & Hematoxilina e Eosina \\
\hline HLA & Human leukocyte antigen (Antígeno leucocitário humano) \\
\hline HLA-DQ6 & $\begin{array}{l}\text { Human leukocyte antigen - allele - DQ6 (Antígeno leucocitário } \\
\text { humano - alelo -DQ6) }\end{array}$ \\
\hline HLA-DQ8 & $\begin{array}{l}\text { Human leukocyte antigen - allele - DQ8 (Antígeno leucocitário } \\
\text { humano - alelo -DQ8) }\end{array}$ \\
\hline HLA-DR2 & $\begin{array}{l}\text { Human leukocyte antigen - allele - DR2 (Antígeno leucocitário } \\
\text { humano - alelo -DR2) }\end{array}$ \\
\hline HLA-DR4 & $\begin{array}{l}\text { Human leukocyte antigen - allele - DR4 (Antígeno leucocitário } \\
\text { humano - alelo -DR4) }\end{array}$ \\
\hline I.E. & Índice de estimulação \\
\hline $\lg$ & Imunoglobulina \\
\hline $\mathrm{IL}$ & Interleucina \\
\hline LMM & Light meromyosin (cadeia leve da miosina) \\
\hline $\mathrm{mg}$ & Miligramas \\
\hline $\mathrm{MHC}$ & $\begin{array}{l}\text { Major histocompatibility complex (Complexo principal de } \\
\text { histocompatibilidade) }\end{array}$ \\
\hline $\mathrm{mL}$ & Mililitro \\
\hline $\mathrm{mM}$ & Milimolar \\
\hline${ }^{\circ} \mathrm{C}$ & Grau centígrado \\
\hline OPD & o-phenylenediamine dihydrochloride (diicloridro ofenilediamina) \\
\hline OVA & Ovalbumina \\
\hline PBS & Phosphate buffered saline (tampão salina-fosfato) \\
\hline PBS-T-G & $\begin{array}{l}\text { Phosphate buffered saline - tween - gelatin (tampão salina - } \\
\text { fosfato - tween - gelatina) }\end{array}$ \\
\hline PCR & Polymerase Chain Reaction (reação de polimerase em cadeia) \\
\hline
\end{tabular}




$\begin{array}{ll}\text { PE } & \text { Phycoerythrin (ficoeritrina) } \\ \text { PercP } & \text { Peridinin chlorophyll protein (proteína clorofil peridina) } \\ \text { pH } & \text { Potencial hidrogeniônico } \\ \text { p/v } & \text { Peso sobre Volume } \\ \text { qsp } & \text { Quantidade suficiente para } \\ \text { R5 } & \text { Meio RPMI suplementado com 5\% de SFB } \\ \text { R10 } & \text { Meio RPMI suplementado com 10\% de SFB } \\ \text { SDS } & \text { Sodium dodecyl sulfate (dodecil sulfato de sódio) } \\ \text { SFB } & \text { Soro fetal bovino } \\ \text { Sfbl } & \text { Fibronectin-binding protein I (proteína ligante de fibronectina) } \\ \text { SLE } & \text { Solução de lise de eritrócitos } \\ \text { SLGB } & \text { Solução de lise de glóbulos brancos } \\ \text { SpeA } & \text { Streptococcal pyogenic exotoxin A (exotoxina pirogênica } \\ \text { SPF } & \text { estreptocócica sorotipo A) } \\ \text { SSC } & \text { Specific pathogen free (livre de patógenos específicos) } \\ \text { TAE } & \text { Side Scatter } \\ \text { Taq } & \text { Tampão tris-acetato/EDTA } \\ \text { TCM } & \text { Termus aquaticus } \\ \text { TCR } & \text { Células T de memória central } \\ \text { TEM } & \text { T Cell receptor (receptor de células T) } \\ \text { U } & \text { Unidades } \\ \text { V } & \text { Volts } \\ \text { vol } & \text { Volume memória efetora } \\ \text { Microlitro }\end{array}$




\section{LISTA DE FIGURAS}

Figura 1: Gel de agarose contendo as bandas de $250 \mathrm{pb}$ referentes ao transgene.... 40

Figura 2: Estratégia de "gate" no ensaio de citometria de fluxo para a deteç̧ão de moléculas HLA-II em leucócitos de camundongos transgênicos.

Figura 3: Porcentagem de células $C D 11 \mathrm{c}^{+}$e $C D 45 / B 220^{+}$que expressam moléculas HLA de classe II DR (camundongos DR2).

Figura 4: Porcentagem de células $C D 11 \mathrm{c}^{+}$e $\mathrm{CD} 45 / \mathrm{B} 220^{+}$que expressam moléculas HLA de classe II DR (camundongos DR4)

Figura 5: Porcentagem de células $C D 11 \mathrm{c}^{+}$e $C D 45 / B 220^{+}$que expressam moléculas HLA de classe II DQ (camundongos DQ6). . .

Figura 6: Porcentagem de células $C D 11 \mathrm{c}^{+}$e $C D 45 / B 220^{+}$que expressam moléculas HLA de classe II DQ (camundongos DQ8).

Figura 7: Demonstração de resultados encontrados no experimento de análise de MHC-II

Figura 8: Presença de moléculas MHC de classe Il encontrada em camundongos DR2 estudados e controles

Figura 9: Presença de moléculas MHC de classe II encontrada em camundongos DR4 estudados e controles

Figura 10: Presença de moléculas MHC de classe II encontrada em camundongos DQ6 estudados e controles.

Figura11: Presença de moléculas MHC de classe II encontrada em camundongos DQ8 estudados e controles

Figura 12: Ensaio imunoenzimático para detecção de imunoglobulinas reativas contra o StreptInCor

Figura 13: Ensaio imunoenzimático de longevidade para deteç̧ão de imunoglobulinas reativas contra o StreptInCor

Figura 14: Ensaio imunoenzimático para detecção das subclasses de imunoglobulinas reativas contra o StreptInCor

Figura 15: Ensaio imunoenzimático para detecção de imunoglobulinas reativas contra o StreptInCor, proteína M1 e controles 
Figura 16: Ensaios imunoenzimáticos para detecção de imunoglobulinas reativas contra o StreptInCor (variabilidade experimental)

Figura 17: Correlação entre o título de anticorpos obtidos nos ensaios de ELISA e a porcentagem de expressão de moléculas HLA-II

Figura 18: Ensaios imunoenzimáticos para detecção de imunoglobulinas reativas contra o StreptlnCor em imunizações com adjuvante de Freund.

Figura 19: Ensaios imunoenzimáticos para detecção de imunoglobulinas reativas contra o StreptInCor e a Ovalbumina.

Figura 20: Demonstração de "gate" diferenciando marcação de células $\mathrm{CD}^{+} / \mathrm{CD}^{+}{ }^{+} \mathrm{CFSE}^{\text {baixo }}$ e $\mathrm{CD}^{+}{ }^{+} \mathrm{CD} 4^{+} \mathrm{CFSE}^{\text {baixo }}$

Figura 21: Índice de estimulação após proliferação dos esplenócitos em cultura (camundongos DR4)

Figura 22: Índice de estimulação após proliferação dos esplenócitos em cultura (camundongos DQ6)

Figura 23: Índice de estimulação após proliferação dos esplenócitos em cultura (camundongos DQ8)

Figura 24: Análise do padrão de proliferação celular em camundongos da linhagem DR4

Figura 25: Análise do padrão de proliferação celular em camundongos da linhagem DQ6

Figura 26: Análise do padrão de proliferação celular em camundongos da linhagem DQ8

Figura 27: Demonstração da análise do tecido cardíaco dos animais imunizados com StreptInCor e salina

Figura 28: Demonstração da análise dos órgãos dos animais imunizados com StreptInCor e salina. 


\section{LISTA DE TABELAS}

TABELA 1: Análise do tecido cardíaco dos animais imunizados com StreptlnCor e salina 63

TABELA 2: Análise do orgãos dos animais imunizados com StreptlnCor e salina ... 64 


\section{Resumo}


Guerino, MT. Avaliação de potencial agente vacinal contra o S. pyogenes em camundongos transgênicos, portadores de genes HLA de classe II humanos [Dissertação].

São Paulo: Faculdade de Medicina, Universidade de São Paulo; 2011

\section{RESUMO}

A faringite estreptocócica desencadeada pelo Streptococcus pyogenes pode resultar em uma série de doenças humanas e complicações como a febre reumática (FR) em indivíduos predispostos não tratados. A FR é uma doença autoimune que afeta mais de 20 milhões de crianças em países em desenvolvimento. A proteína M presente na membrana do $S$. pyogenes representa o maior fator de virulência da bactéria, e é objetivo de estudos para o desenvolvimento de uma vacina contra essa patologia. Atualmente mais de 200 tipos de proteínas M foram descritos na literatura e a sua porção C-terminal é conservada entre os diferentes tipos. Desenvolvemos um protótipo de vacina que compreende 55 resíduos de aminoácido da porção C-terminal, denominado "StreptInCor". Neste trabalho analisamos a resposta humoral e celular específica contra o peptídeo sintético StreptInCor, usando camundongos transgênicos portadores de HLA de classe II humanos DR2, DR4, DQ6 e DQ8. O protocolo de imunização consistiu em administrar $50 \mu \mathrm{g}$ do StreptInCor adsorvido em $300 \mu \mathrm{g}$ de hidróxido de alumínio nos dias 0 e 14. Os grupos controles foram injetados com salina nas mesmas condições. O soro obtido no $28^{\circ}$ dia foi testado por ensaio imunoenzimático (ELISA) para verificarmos a presença de anticorpos contra o StreptlnCor e os esplenócitos destes animais, obtidos nessa data, foram utilizados para ensaios de proliferação celular na presença do StreptInCor. Testes de segurança foram efetuados e não observamos reação cruzada contra a miosina cardíaca e após 12 meses de acompanhamento, amostras de tecidos desses animais foram submetidas à análise histológica. Em conclusão não verificamos indícios de reações autoimunes nos animais imunizados com o StreptlnCor e os resultados obtidos mostram a capacidade do StreptlnCor em desencadear uma resposta imune, duradoura e segura em camundongos portadores de moléculas HLA de classe II.

Descritores: 1. Vacinas estreptocócicas 2. Camundongos transgênicos 3. Genes classe II do complexo de histocompatibilidade (MHC) 4. Imunidade humoral 5. Imunidade celular 
Guerino, MT. Evaluation of Potential Vaccinal Agent Against S. Pyogenes in Human HLA Class II Transgenics Mice [Dissertation]. São Paulo: Faculdade de Medicina, Universidade de São Paulo; 2011

\section{ABSTRACT}

Streptococcal pharyngitis triggered by Streptococcus pyogenes throat infection can result in rheumatic fever (RF) and rheumatic heart disease (RHD) in untreated susceptible individuals. RF is an autoimmune disease that affects more than 20 million children in developing countries. M protein is the major factor of virulence of the bacteria, and it has been studied to develop a vaccine. Currently more than $200 \mathrm{M}$ protein types have been described and its Cterminal domain is conserved in many different serotypes. We developed a vaccine epitope (StreptInCor) composed by 55 amino acid residues of the $\mathrm{C}$ terminal portion of the $\mathrm{M}$ protein. In the present work we analyze the ability of the StreptInCor of induce immune response in HLA class II transgenic mice. The transgenic mice harboring the HLA Class II DR2, DR4, DQ6 and DQ8 were immunized subcutaneously with $50 \mu \mathrm{g}$ StreptInCor adsorbed onto $300 \mu \mathrm{g}$ of aluminum hydroxide gel on days 0 and 14 . Control groups were immunized with vehicle (Saline) in same conditions. The sera were obtained on day 28 and tested by ELISA to verify the presence of antibodies. The specific cellular immune response was evaluated by proliferation assay using splenocytes. No cross reaction with cardiac myosin were observed. Tissue samples from immunized mice followed by 12 months were analyzed in order to verify if StreptInCor induces some histological damage. No autoimmune or deleterious reactions were observed. In conclusion our results indicate that StreptInCor Induces a good and prolonged and safe immune response in HLA class II transgenic mice.

Descriptors: 1. Streptococcal Vaccine 2. Transgenic mice 3. Genes MHC class II 4. Humoral immunity 5 . Cellular immunity 


\section{Introdução}




\section{Introdução}

O Streptococcus pyogenes é a bactéria causadora de uma série de doenças humanas, tendo como principal sítio de infecção a orofaringe, desencadeando uma faringoamigdalite não supurativa. Também pode ocasionar doenças cutâneas, invasivas, sistêmicas e complicações tardias e de ordem autoimune como a febre reumática $(F R)$ e a glomerulonefrite. Pela diversidade de doenças desencadeadas por este patógeno, as complicações ocasionadas, principalmente a febre reumática que tem como conseqüência principal a doença reumática cardíaca (DRC), que é responsável pelo alto custo gerado no tratamento e cirurgias, se faz necessário uma intervenção medicamentosa para inibir o número de indivíduos acometidos por essas doenças e evitar suas complicações.

Nesse intuito, o desenvolvimento de uma vacina seria a melhor opção, uma vez que é considerada uma das mais seguras e eficazes intervenções de saúde pública, prevenindo mais de três milhões de mortes anualmente pelo $S$. pyogenes (O'Hagan \& Rappuoli, 2006). Neste trabalho avaliamos a capacidade imunogênica do agente vacinal contra o S. pyogenes, denominado StreptInCor, produzido no Instituto do Coração (Guilherme et al, 2006; Guilherme et al, 2009), utilizando camundongos transgênicos, portadores de genes do complexo principal de histocompatibilidade de classe II (MHC-II) humanos. 


\subsection{O Streptococcus pyogenes}

O Streptococcus pyogenes ou estreptococo beta hemolítico do grupo A, segundo classificação de Lancefield (1962), é uma bactéria Gram positiva disposta em cadeias compostas por cocos, com cerca de 0,5 - 1 micrômetros cada. Estas bactérias apresentam paredes celulares grossas e uma membrana simples. As camadas médias e internas das paredes celulares são compostas pelos açucares $\mathrm{N}$-acetil glucosamina e ramnose que conferem rigidez à parede, mantendo a morfologia bacteriana.

O S. pyogenes é uma bactéria anaeróbia facultativa, catalase-negativa e produz substâncias capazes de promover a evasão ao sistema imunológico como a peptidase C5a que inibe a ação do sistema complemento pela da destruição do fator C5a, estreptolisinas $\mathrm{S}$ e $\mathrm{O}$ que lisam a membrana de eritrócitos, exotoxinas pirogênicas que promovem um quadro febril e podem induzir insuficiência de órgãos e até mesmo o choque, DNAses e hialuronidases. Entre as estruturas que lhe confere fatores de virulência estão o ácido lipoteicóico (LTA), que é um polímero longo, composto por fosfoglicerol, responsável pela ligação da bactéria à fibronectina epitelial da orofaringe do hospedeiro, a cápsula composta de ácido hialurônico, que é quimicamente idêntico ao existente no organismo humano e auxilia na evasão da bactéria ao sistema imunológico, a proteína F que é uma adesina e a proteína M.

Dentre as diversas estruturas antigênicas do $S$. pyogenes a mais importante e, conseqüentemente, mais estudada é a proteína $M$, que tem a capacidade de aderir a fibronectina do epitélio da orofaringe, interage com o 
fibrinogênio mascarando a presença da bactéria e pode se fixar na porção Fc dos anticorpos bloqueando sua interação com fagócitos.

A proteína M apresenta uma estrutura fibrilar trans-membrana disposta em dupla alfa hélice. Essa proteína, que é codificada pelo gene emm do $S$. pyogenes, contém aproximadamente 450 resíduos de aminoácidos dispostos em quatro regiões ( $A, B, C$ e D), cada uma apresentando sub-regiões específicas (A1-5, B1-4, C1-3, D1-4). A região N-terminal é a mais polimórfica (regiões $A$ e $B$ ), pequenas variações na seqüência de aminoácidos de suas sub-regiões classificam as diferentes cepas de $S$. pyogenes, dentre as quais algumas são reumatogênicas enquanto outras não. Existem mais de 180 seqüências de tipos emm e 800 subtipos emm descritas (Carapetis et al, 2005; Smeesters et al, 2010; Steer et al, 2007), os sorotipos 1, 3, 5, 6, 12, 14, 18, 19, 22, 24, 27 e 29 foram considerados predominantemente reumatogênicos, ou seja, capazes de desencadear febre reumática (revisado por Cunningham, 2000). A porção C-terminal (regiões C e D), mais proximal à membrana da bactéria, é altamente conservada entre as diferentes cepas, sendo que $85 \%$ das cepas S. pyogenes já descritas, apresentam suas sub-regiões C2 e C3 homólogas (Smeesters et al, 2010).

\subsection{Doenças desencadeadas pelo S. pyogenes}

As doenças causadas pelo $S$. pyogenes podem ser divididas em superficiais, invasivas e complicações tardias. A faringoamigdalite estreptocócica é o acometimento mais comum ocasionado pela bactéria. Entre as doenças cutâneas as principais doenças desencadeadas são erisipela, 
impetigo e a escarlatina. A erisipela é uma infecção cutânea aguda caracterizada por intenso rubor da área afetada, dor, febre e calafrios, geralmente precedida de infecções respiratórias, sendo mais comum em crianças e idosos. Impetigo é uma infecção cutânea superficial que acomete principalmente a face e mãos, geralmente é secundária a uma lesão préexistente, caracterizando se por vermelhidão em sua fase inicial, evoluindo para secreção purulenta e formação de crostas na fase cicatricial. Já a escarlatina é uma resposta inflamatória cutânea às toxinas do $S$. pyogenes $e$ tem como característica erupções de diversas pápulas avermelhadas (rash), que apresenta tom levemente áspero. Essas erupções costumam ocorrer na cabeça e disseminar para o resto do corpo, ocorrendo aglomeração em regiões de dobras como axila e virilha.

Entre as doenças invasivas ocasionadas pelo $S$. pyogenes estão a fasciite necrosante e a síndrome do choque tóxico, ambas desencadeadas pela infiltração da bactéria em lesões pré-existentes. No caso da fasciite necrosante a bactéria alcança as fáscias musculares, colonizando essa região e necrosando o tecido lipídico e da derme adjacente. Essa doença conferiu ao $S$. pyogenes o nome de bactéria devoradora de carne ("flesh eating bactéria"). Quando a bactéria atinge a corrente sanguínea ela desenvolve a síndrome do choque tóxico, gerando um quadro generalizado de sepse com diversos focos hemorrágicos.

Existem ainda as doenças tardias de origem estreptocócica como a glomerulonefrite pós-estreptocócica e a febre reumática (FR). A deposição de imunocomplexos nos glomérulos, em decorrência da tentativa do sistema imune combater o S. pyogenes, causa uma glomerulonefrite com lesão renal 
homogeneamente difusa e com infiltrado inflamatório. Apresenta como quadro clínico a síndrome nefrítica com aparecimento súbito de edema, hematúria macroscópica e hipertensão arterial. Sua cronicidade pode levar a uma falência renal. A FR é uma doença auto-imune resultante de uma complicação tardia de uma faringoamigdalite estreptocócica, não supurativa, incidente em indivíduos predispostos geneticamente e não tratados. A doença incide preferencialmente em crianças e jovens com idades entre 5 e 18 anos, sendo rara antes dos 3 anos de idade. Em um período de 15 a 21 dias após a infecção de orofaringe, 0,3 a 3\% dos indivíduos desenvolvem a doença (Bisno, 2001; Cunningham, 2000).

As manifestações clínicas da FR se caracterizam pelo acometimento das articulações (poliartrite migratória), pele (eritema marginado e/ou nódulos subcutâneos), sistema nervoso central (coréia de Sydenham) ou no coração (cardite/valvulite) (Snitcowsky, 1996). A Poliartrite Migratória é caracterizada por um acometimento de grandes articulações, sendo originada por autoanticorpos dirigidos contra a sinóvia e a cartilagem articular. No eritema marginado há a presença de lesões cutâneas de aspecto róseo de bordos serpiginosos ou circulares e centro pálido, de caráter evanescente, não pruriginoso, sendo precipitadas por calor ou pressão e de localização preferencial em tronco e parte proximal dos membros. Os nódulos subcutâneos apresentam consistência firme, são móveis e indolores e estão presentes sobre proeminências ósseas ou trajetos de tendões. Podemos encontrá-los também sobre as apófises espinhosas da coluna vertebral e na região occipital.

A manifestação neurológica da FR é a coréia de Syndeham, costuma aparecer até seis meses após a infecção de orofaringe e é caracterizada pela 
presença de auto-anticorpos dirigidos contra neurônios dos núcleos caudado e subtalâmico originando alterações psico-neurológicas (Snitcowsky, 1996). Tem início insidioso caracterizado, geralmente, por labilidade emocional e fraqueza muscular que dificultam o diagnóstico. Os indivíduos acometidos apresentam movimentos rápidos involuntários e não coordenados, que desaparecem durante o sono e são acentuados em situações de estresse e esforço. Esses movimentos podem acometer músculos da face, lábios, pálpebras e língua e são, com freqüência, generalizados.

A forma mais grave da FR é a doença reumática cardíaca (DRC) (Grinberg et al, 1985; Guilherme et al, 2000). Esta patologia, que acomete aproximadamente $30 \%$ dos pacientes com FR, constitui-se na principal causa de doenças cardíacas em crianças no mundo, sobretudo em países menos desenvolvidos (Kaur et al, 1998). A DRC é caracterizada por lesões inflamatórias, que podem ser encontradas em vários sítios. Estes infiltrados inflamatórios, denominados nódulos de Aschoff, constituem o sinal patognomônico da doença e são compostos por focos de necrose fibrinóide cercados por neutrófilos, eosinófilos e macrófagos além de linfócitos T e B (Chopra et al, 1988; Kemeny et al, 1989).

Alguns estudos sugerem que seqüências de aminoácidos presentes na região $\mathrm{N}$-terminal da proteína $\mathrm{M}$ apresentam alta homologia com proteínas humanas. Kaplan et al, (1963) mostrou que anticorpos dirigidos contra o tecido cardíaco humano foram capazes de reconhecer estruturas da parede do $S$. pyogenes, assim como a proteína M e tecidos tissulares humanos, sugerindo o desencadeamento de autoimunidade devido a um mimetismo molecular. As proteínas humanas reconhecidas cruzadamente foram: laminina, queratina, 
actina, vimentina, miosina e tropomiosina. Posteriormente, a proteína $M$ presente na membrana celular bacteriana foi reconhecida como responsável pelo desencadeamento dessas reações auto-imunes (Dale \& Beachey, 1986; Jones et al, 1986; Kraus et al, 1990; Kraus et al, 1989a; Kraus et al, 1989b; Sargent et al, 1987).

Anticorpos reativos ao tecido cardíaco, por reação cruzada com antígenos do estreptococo, ao fixarem à parede do endotélio valvar, aumentam a expressão da molécula de adesão VCAM-I, e favorece a indução de quimiocinas, principalmente CCL5. Estas quimiocinas favorecem a infiltração de linfócitos $\mathrm{T}$ de memória e outras células mononucleares, que irão produzir principalmente citocinas inflamatórias do tipo Th1 (IFNy e TNFa) e baixas quantidades de IL-4, que por sua vez, é uma citocina reguladora da resposta inflamatória. Como as lesões valvulares reumáticas são lentas e progressivas, esse desequilíbrio entre citocinas inflamatórias e regulatórias no tecido cardíaco, assim como o recrutamento constante de linfócitos de memória, perpetua a inflamação local, levando a destruição tecidual e necrose. No miocárdio, devido ao grande número de células produtoras de IL4, ocorre cura da miocardite após algumas semanas de tratamento antiinflamatório (Cunningham, 2000; Guilherme et al, 2004; Guilherme et al, 2007a; Roberts et al, 2001).

A pancardite de origem reumática pode acometer endocárdio, manifestando-se em surtos agudos como insuficiência de válvula mitral e aórtica promovendo regurgitação. Ao longo da evolução da doença, pode ainda ocorrer estenose valvar. Esta patologia pode, conseqüentemente, promover internações repetidas, intervenções cirúrgicas cardiovasculares 
complexas (Snitcowsky, 1996) e tratamento medicamentoso de difícil manejo. Isto acaba influenciando a capacidade laborativa e escolar dos pacientes e seus responsáveis, levando direta ou indiretamente aos altos custos sociais.

\subsection{Susceptibilidade genética}

O fato de apenas uma parte da população desenvolver FR, apesar da maioria dos indivíduos ter entrado em contato com a bactéria, sugere que fatores genéticos estão associados ao desenvolvimento da patogenia. Nesse contexto, estão envolvidos os genes do complexo principal de histocompatibilidade (MHC, do inglês "Major Histocompatibility Complex"), que estão alocados no braço curto do cromossomo 6 em humanos e no cromossomo 17 em camundongos e que receberam esse nome devido a sua importância nos estudos, realizados por Snell et al.(1957), sobre rejeição de tecidos transplantados em camundongos.

Esses genes são os mais polimórficos do genoma humano e codificam moléculas com capacidade de ancorar, em sua fenda de ligação, seqüências peptídicas de antígenos processados, no interior das células, e que serão expressas em sua superfície. Existem duas classes de moléculas MHC (Classe I e Classe II), sendo que as de Classe I estão presentes em todas as células nucleadas e são responsáveis pela apresentação de antígenos próprios (endógenos) para os linfócitos T CD8 ${ }^{+}$(citotóxicos). As moléculas de classe II são expressas na superfície de células apresentadoras de antígeno (APC - do inglês, "Antigen Presenting Cells"), como macrófagos, células dendríticas e

linfócitos $B$, que são os responsáveis pela captura, processamento e 
apresentação de antígenos estranhos (exógenos) aos linfócitos T CD4 ${ }^{+}$, auxiliadores, (revisto em: (Germain \& Jenkins, 2004). O reconhecimento dos antígenos ancorados às moléculas de $\mathrm{MHC}$ I ou II é restrito ao receptor de linfócitos T (TCR, do inglês, “T Cell Receptor") que, com a ajuda de sinais coestimulatórios, desencadeia uma cascata de ativação intracelular (Rosenthal \& Shevach, 1973) e leva a proliferação de clones desses linfócitos, específicos ao antígeno apresentado, e a produção de citocinas e anticorpos estabelecendose assim uma resposta imunológica específica (revisto em: (Germain \& Jenkins, 2004).

Em humanos, as moléculas $\mathrm{MHC}$ receberam o nome de antígeno leucocitário humano (HLA, do inglês, "Human Leukocyte Antigen"), por serem descobertas primeiramente na superfície de leucócitos. O HLA de classe I apresenta como produto gênico as moléculas HLA-A, B e C, já o HLA de classe II apresenta as moléculas HLA-DR, DQ e DP e em ambas as classes de moléculas HLA há um enorme polimorfismo que gera uma gama de alelos para cada molécula. Em camundongos o MHC é chamado $\mathrm{H}-2$ e tem como moléculas de classe $\mathrm{I} \circ \mathrm{H}-2 \mathrm{~K}, \mathrm{D}$ e $\mathrm{L}$ e as moléculas de classe II são denominadas IA e IE. As funções desempenhadas pelas moléculas MHC em humanos e murinos são as mesmas, e elas apresentam estruturas semelhantes, sendo heterodímeros compostos por uma cadeia alfa e outra beta. Além disto, as moléculas de classe I humanas e murinas estão associadas à molécula de Beta 2-microglobulina em sua estrutura para auxiliar em sua estabilização e ancoragem à membrana das células.

O polimorfismo das moléculas de MHC se concentra na fenda de ligação dos antígenos, sendo que essa região apresenta bolsos com afinidades para a 
ligação de determinados aminoácidos da seqüência peptídica dos antígenos que serão apresentados ao TCR. Devido a esse fato, determinados alelos HLA poderiam apresentar seqüências peptídicas dos antígenos com alta homologia a proteínas estruturais humanas, podendo desencadear uma resposta imunológica cruzada devido a mimetismo molecular, levando assim a uma resposta auto-imune.

Certos alelos do $\mathrm{MHC}$ de classe II estão altamente relacionados à herança, susceptibilidade ou a resistência às doenças auto-imunes Eroglu \& Kohler, 2002 demonstraram uma associação significante em indivíduos caucasianos, portadores de HLA-DR2, no desenvolvimento de lúpus eritematoso sistêmico (LES). Ao estudar uma amostra de brasileiros caucasianos, Fernandes et al. (2002) mostrou que portadores heterozigotos dos alelos HLA-DR3/DR4 apresentavam risco relativo elevado para o desenvolvimento da Diabetes Mellitus do tipo 1 (DM-1), enquanto que os antígenos HLA-DR2 e mais fracamente HLA-DR5 raramente são encontrados entre os pacientes com DM-1, estando esses alelos associados a uma resistência ao desenvolvimento da doença.

Entre os alelos HLA de classe II, vários alelos HLA DR mostraram associações com o desenvolvimento da FR em diversos países (revisado por (Guilherme et al, 2007b), como DR2 e DR4 na população americana (Anastasiou-Nana et al, 1986), DR4 na Arábia Saudita (Rajapakse et al, 1987), DR1 e DR6 na África do Sul (Maharaj et al, 1987) e DR7 e DR11 na Turquia (Olmez et al, 1993). No Brasil, ao estudar uma amostra da população, constituída por mulatos escuros e claros, nosso grupo observou uma 
associação do desenvolvimento da FR com os alelos HLA de classe II DR7 e DR53 (Guilherme et al, 1991; Weidebach et al, 1994).

\subsection{Epidemiologia}

Estima-se que haja mais 100 milhões de casos de doenças cutâneas e mais de 600 milhões de casos de faringite de origem estreptocócica por ano. No ano de 2005 a Organização Mundial de Saúde (OMS) registrou 15.600.000 casos de portadores de DRC, sendo que há a estimativa de 300.000 novos casos e 233.000 mortes a cada ano diretamente atribuíveis a DRC (Carapetis et al, 2005), porém esses dados não refletem a realidade dos países subdesenvolvidos, principalmente em regiões pobres, onde os sistemas de notificações da doença pelos centros de atendimento são falhos e pela falta de programas de controle.

No ano de 2007, do total de cirurgias cardíacas realizadas no Brasil, $31 \%$ envolveram pacientes acometidos pela FR, gerando um custo superior a 157 milhões de reais ao Sistema Único de Saúde (SUS), em tratamento e cirurgias devido a FR e a DRC. A taxa de mortalidade devido a DRC neste período foi de 7,5\% (DATASUS). Estima-se que haja 10 milhões de casos de faringoamigdalites de origem estreptocócicas por ano, levando a um total de 30.000 novos casos de FR por ano, sendo que metade destes casos pode evoluir para a DRC (Cardiologia, 2009).

\subsection{Tratamento e profilaxia}

As intervenções medicamentosas que visam alterar o curso da infecção levam em consideração o reconhecimento precoce e tratamento da 
faringoamigdalite de origem estreptocócica. A droga de escolha para o tratamento deste tipo de infecção é a penicilina-benzatina, pois apresenta baixa incidência de efeitos colaterais, tem eficácia clínica e bacteriológica e a susceptibilidade da bactéria à droga já foi comprovada, além do tratamento ter um baixo custo. O diagnóstico precoce, com identificação do microrganismo envolvido, é difícil ser realizado em países subdesenvolvidos, uma vez que o desenvolvimento das doenças estreptocócicas e suas complicações está associado diretamente à fatores sócio-ambientais e portanto a falta de tratamento adequado faz com que nesses países a incidência de FR seja até vinte vezes maior do que em países desenvolvidos.

Diante desses fatos, se torna clara a necessidade de uma vacina capaz de impedir a colonização da bactéria à orofaringe, evitando que surjam as complicações decorrentes dessa infecção e que confira aos indivíduos susceptíveis uma imunização prévia a bactéria.

Vários grupos têm procurado desenvolver uma vacina eficaz contra o estreptococo, sobretudo utilizando antígenos bacterianos para a produção de uma vacina de subunidade. Nesse sentido, diversas proteínas bacterianas estão em estudo como C5a peptidase, SpeA (do inglês, Streptococcal pyrogenic exotoxin), cisteína protease e proteína ligante de fibronectina (Sfbl). Entretanto, por ser a proteína mais antigênica do S. pyogenes, a proteína M é o principal alvo para a produção de uma vacina.

Utilizando coelhos, Beachey et al. (1987) observaram a formação de anticorpos opsonizantes específicos para as proteínas $M$, quando estes foram imunizados com as porções N-terminais das proteínas M5, M6 e M24, 
conjugadas a uma proteína carreadora. O uso de proteínas recombinantes com seqüências $\mathrm{N}$-terminais de quatro sorotipos - M24, M5, M6, M19 - induziu anticorpos específicos em coelhos sem causar reatividade contra o tecido cardíaco (Dale et al, 1993). Este grupo desenvolve ensaios de vacina sorotipo-específicas para cepas freqüentes nos Estados Unidos, usando seqüências $N$-terminais da proteína $M$ de 26 sorotipos: $M 1,1.2,2,3,5,6,11$, 12, 13, 14, 18, 19, 22, 24, 28, 29, 33, 43, 59, 75, 76, 77, 89, 92, 101, 114 (Dale, 1999a; Dale, 1999b; Dale et al, 1999; Hu et al, 2002). Atualmente essa é a única vacina contra o $S$. pyogenes que já se encontra em testes clínicos, porém sua cobertura vacinal é restrita aos sorotipos prevalentes nos Estados Unidos (Shulman et al, 2009).

A porção C-terminal da proteína $\mathrm{M}$, por outro lado, é conservada em mais de $80 \%$ das cepas (Fischetti, 1989). Peptídeos sintéticos da região constante da proteína M6, covalentemente ligados à subunidade da toxina colérica (CTB) foram administrados em camundongos, por via intranasal, em três doses semanais e após o desafio apresentou uma redução significativa da colonização por estreptococos, quando comparados aos camundongos que foram tratados somente com a CTB (Bessen \& Fischetti, 1988a; Bessen \& Fischetti, 1988b; Bessen \& Fischetti, 1990). O mesmo grupo utilizou a região conservada da proteína $\mathrm{M}$, utilizando o vírus da vaccínia como vetor, para a construção de um novo modelo de vacina (Fischetti, 1989; Fischetti et al, 1989). Apesar dos resultados promissores, obtidos com as duas vacinas, o custo da conjugação no primeiro modelo e o uso do vírus da vaccínia pela via oral limitou o uso destas vacinas em humanos. 
Pesquisadores australianos ao imunizar camundongos com peptídeos conservados, oriundos da região C-terminal da proteína M5, induziram a produção de anticorpos com atividade bactericida em ensaios "in vitro". Dois peptídeos sintéticos foram construídos e várias formulações têm apresentado resultados promissores. A combinação deste peptídeo com uma proteína estreptocócica, ligante de fibronectina (Sfbl) aumentou a capacidade de proteção contra o S. pyogenes em camundongos (Olive et al, 2007).

Atualmente este grupo tem voltado seus esforços para a construção de uma vacina baseada em um epítopo B oriundo da região C-terminal da proteína M do S. pyogenes, um epítopo T universal e lipoproteínas alvos de receptores "Toll-like" (TLR, do inglês, "Toll-like receptors"), esses receptores tem papel fundamental no desencadeamento da resposta imune inata pelo reconhecimento de estruturas altamente conservadas em microrganismos patogênicos, chamados receptores de reconhecimento padrão (PAMPs, do inglês, "pathogen associated microbial pattern"). Dessa forma, esse grupo espera desenvolver uma resposta imune humoral específica a proteínas da bactéria com envolvimento de linfócitos $\mathrm{T}$ e estimulação da resposta imune inata (Abdel-Aal et al, 2010).

O epítopo B dessa vacina contém 14 resíduos de aminoácidos (denominado J14), e foi selecionado pela sua incapacidade de promover reatividade cruzada às células $\mathrm{T}$. Como este epítopo era linear e não mantinha a conformação helicoidal encontrada "in natura", na bactéria, foi sintetizado um peptídeo quimérico contendo a seqüência J14 e um peptídeo que lhe conferisse uma estrutura helicoidal semelhante à encontrada na proteína $M$ (Relf et al, 1996). O epítopo T escolhido para compor a vacina gera uma 
resposta imunológica inespecífica, ou seja, apenas apresenta a função de recrutar células $\mathrm{T} \mathrm{CD4}^{+}$. Por fim a utilização de lipoproteínas capazes de reconhecimento pelos receptores do tipo "Toll" (TLR) vêm sendo extensamente estudadas e pode apresentar uma boa estratégia imunoestimulante no desenvolvimento de vacinas.

\subsection{O peptídeo vacinal sintético StreptInCor}

O conhecimento gerado nos diversos estudos e principalmente os trabalhos sobre os mecanismos de patogênese desenvolvidos em nosso laboratório nos levaram ao processo de desenvolvimento de uma vacina profilática segura contra estreptococcias. O potencial agente vacinal foi desenvolvido com base em seqüências conservadas da região C-terminal da proteína M5 do S. pyogenes, contendo os resíduos 253 - 350, compreendendo um total de 100 aminoácidos. Foram sintetizados em nosso laboratório 79 peptídeos, contendo 20 resíduos de aminoácidos cada, e com diferença de 1 resíduo em cada extremidade.

Os 79 peptídeos sintetizados foram testados com 620 amostras de soro humano, em ensaios de ELISA, para definir o epítopo B imunodominante, enquanto que o epítopo $T$ imunodominante foi definido por ensaios de proliferação celular, com amostras de células mononucleraes de sangue periférico (PBMC do inglês, "Peripheral mononucleas cells") de 260 indivíduos diferentes. As amostras de soro e de PBMC utilizadas no estudo foram obtidas de indivíduos sadios, portadores de FR e de DRC. 
O epítopo B é composto por seqüência de 22 resíduos de aminoácidos e o epítopo T por uma seqüência de 25 resíduos de aminoácidos, dos quais 16 são compartilhados devido às regiões de repetição da porção C-terminal da proteína M5 (Guilherme et al, 2006). A partir da seleção dos epítopos T e B em humanos, sintetizamos um peptídeo de 55 resíduos, denominado StreptInCor, que contém os epítopos B e T, ligados entre si por 08 resíduos de aminoácidos, em conformidade com o segmento natural da proteína M5 como segue:

\section{KGLRRDLDASREAKKQLEAEQQKLEEQNKISEASRKGLRRDLDASREAKKQVEKA}

\section{EPÍTOPO T}

EPÍTOPO B

A análise do StreptInCor por ressonância magnética nuclear (NMR, do inglês nuclear magnetic resonance) mostrou que o epítopo T imunodominante, originado da região C2 da proteína M5, apresenta estrutura em a-hélice em conformidade com a proteína original e o epítopo B imunodominante, originado da região C3, não apresenta essa característica conformacional, o que favorece a interação direta entre antígeno e anticorpo levando a um reconhecimento e indução de linfócitos B de memória. A predileção da ligação dos 55 resíduos de aminoácidos que compõem o StreptlnCor, após seu processamento, mostrou que sua estrutura é favorável à interação da molécula MHC de classe II e os receptores de linfócitos T (TCR), assim como um forte indício da sua capacidade de apresentação pelas APC de indivíduos portadores de qualquer molécula HLA de classe II (Guilherme et al, 2011). 


\subsection{Estudo experimental com o StreptInCor.}

O Streptococcus pyogenes é uma bactéria que causa doenças apenas em humanos, portanto não existe um modelo experimental que possa ser utilizado como modelo de doença estreptocócica, todavia é possível avaliar o comportamento imunológico desses modelos frente a um agente vacinal pela avaliação da resposta imunológica humoral e celular. O StreptlnCor, agente vacinal na forma de peptídeo sintético, foi testado em camundongos, utilizandose o adjuvante de Freund e o hidróxido de alumínio.

Camundongos das linhagens isogênicas BALB/c e C57BL/6 ("inbred") e a linhagem heterogênica Swiss ("outbred") apresentaram ótima resposta humoral contra o StreptInCor, independente do adjuvante utilizado, com alta produção de lgG. Não houve resposta cruzada contra miosina cardíaca ou extrato de proteínas cardíacas obtidas de coração de rato Lewis. Soros de animais imunizados inibiram "in vitro" a adesão de $S$. pyogenes às células de orofaringe. Desafio com a cepa M1 (mais prevalente em episódios de estreptococcias) de animais imunizados com o StreptInCor mostrou que estes encontravam-se protegidos contra o S. pyogenes, quando comparados aos grupos controle.

A análise histopatológica dos órgãos dos animais imunizados mostrou que a administração do StreptInCor não induziu toxicidade nos mesmos. Em conjunto, estes dados indicam que o StreptInCor tem alto potencial de 
imunização, não apresentando até o momento, nenhuma resposta cruzada contra proteínas cardíacas e nem ação tóxica contra tecidos dos animais vacinados, o que o torna candidato para a manufatura de uma vacina segura contra o S. pyogenes.

Devido à grande importância das moléculas HLA (do inglês, Human Leukocyte Antigen), tanto no desenvolvimento de uma resposta imune protetora como deletéria (auto-imune), contra o $S$. pyogenes, torna-se interessante avaliar o papel destas moléculas em estudos pré-clinicos no desenvolvimento de um agente vacinal.

\subsection{Camundongos Transgênicos}

Modelos experimentais transgênicos que expressam genes MHC de classe II humano surgiram como possíveis ferramentas para o estudo de doenças auto-imunes, associadas às moléculas do complexo principal de histocompatibilidade. Linhagens de camundongos deficientes para os genes MHC de classe II murinos Ea e $A \beta$, foram usados para estudar 0 desencadeamento de patologias associadas ao MHC de classe II humano, pela inserção do transgene MHC-Il humano de interesse. No entanto, a possibilidade de ocorrer pareamento entre as moléculas de MHC-II humanas e as cadeias do $\mathrm{MHC}$ murinos $\mathrm{E} \beta$ e Aa remanescentes, formando dímeros entre alelos e gerando complexos quiméricos permissíveis entre espécies (Ex. DRa: $\mathrm{E} \beta$ ), poderiam alterar o repertório de linfócitos T e interferir na interpretação dos estudos (Ishimoto et al, 1997; Lawrance et al, 1989; Trembleau et al, 1995). Nesse sentido, seria desejável que os modelos experimentais apresentassem 
um MHC-II completamente "humanizado", na ausência de artefatos provenientes de seu MHC-II murino. Para contornar esse problema Madsen et al. (1999) desenvolveram linhagens de camundongos que apresentavam uma deleção total dos genes MHC-II murinos (AEo). Os genes Aa e E $\beta$ desses animais foram completamente perdidos enquanto os genes $A \beta$ e Ea foram irremediavelmente silenciados. Assim sendo, esses animais são excelentes hospedeiros para qualquer transgene MHC-II, uma vez que não há o risco de geração de uma molécula quimérica de MHC-Il e pelo fato de todos os outros conhecidos genes envolvidos na apresentação antigênica (M, O, TAP, lócus MHC-I) estarem devidamente expressos (Madsen et al, 1999). Sendo assim a resposta imunológica, gerada nesse modelo experimental, a partir de células $\mathrm{T}$ são estritamente restritas as moléculas transgênicas de MHC de classe II (Cheng et al, 2003).

Os camundongos HLA-DR2 tiveram o gene DRB1*1502 inserido em camundongos B10.RQB3 (AaqAbqEbqEak) que expressam a molécula H2Aq. A região Ebq está mutada nesta linhagem, não sendo funcional. Os animais que receberam o gene foram entrecruzados por 10 gerações. A região Eak é homóloga a DRa, pareando com DRB1*1502. Esses animais têm a prevalência do "background" de MHC classe I H2q (Gonzalez-Gay et al, 1996).

Já os camundongos HLA-DR4 partiram de um cruzamento entre SWR (q2) e B10 (H2b). O gene DR4 $\beta$ foi inserido em óvulos provenientes desse cruzamento. Os animais positivos para DR4 $\beta$ foram entrecruzados e a progênie foi cruzada com B10.RFB3 (H2f). Esses animais têm, portanto, um "background" genético $\mathrm{H} 2 \mathrm{q} 2, \mathrm{H} 2 \mathrm{~b}, \mathrm{H} 2 \mathrm{f}$ sendo principalmente $\mathrm{H} 2 \mathrm{f}$ (Pan et al, 1998). 
Os camundongos HLA-DQ6 tiveram os genes DQA1*0103 e DQB1*0601 inseridos em embriões provenientes da F2 do cruzamento CBA/j e B10.M, gerando os animais B10.M-DQ6 (H-2Af/f). Os animais B10.M-DQ6 foram cruzados com a linhagem $\mathrm{H}-2 \mathrm{AbO}(\mathrm{H}-2 \mathrm{Ab0} / 0)$, gerando camundongos HLADQ6+-H2Ab0. Portanto esses animais são H2k, H2f cruzados com Hb0, 129 (H2b) (Bradley et al, 1997).

HLA-DQ8 foram inseridos os genes DQA1*0301 e DQB1*0302 em embriões provenientes da F2 do cruzamento CBA/j e B10.M, que foram cruzados com a linhagem $\mathrm{H}-2 \mathrm{Ab0}(\mathrm{H}-2 \mathrm{Ab0} / 0)$, gerando os HLA-DQ8+-H2Ab0. Portanto esses animais são predominantemente $\mathrm{H} 2 \mathrm{k}, \mathrm{H} 2 \mathrm{f}$ cruzados com Hb0, 129 (H2b) (Nabozny et al, 1996).

Avaliamos, neste trabalho, a resposta imune humoral e celular de camundongos transgênicos, portadores de genes HLA de classe II humanos DRB1.1502 (DR2), DRB1.0401 (DR4), DQB1.0601 (DQ6) e DQB1.0302 (DQ8), imunizados com o StreptlnCor. Esses animais foram utilizados por apresentarem moléculas de MHC de classe II humanos e, portanto, pela possibilidade de mostrar uma apresentação antigênica semelhante à encontrada em humanos e verificar a possibilidade desencadeamento de autoimunidade ou sinais deletérios. 
Objetivos 


\section{Geral:}

Avaliar a indução de resposta imune ao StreptlnCor em camundongos geneticamente modificados, portadores de genes que codificam para moléculas HLA de classe II humanos.

\section{Específicos:}

- Avaliar a indução de anticorpos específicos e subclasses de imunoglobulinas;

- Avaliar a indução de resposta imune celular;

- Avaliar a segurança do StreptlnCor pela análises histopatológicas nos órgãos dos animais imunizados e controles. 


\section{Animais}

Para a execução desse trabalho foram utilizados camundongos transgênicos, machos e fêmeas, portadores de gene HLA de classe II humano DRB1.1502(DR2).AEo, DRB1.0401 (DR4).AEo, DQB1.0601 (DQ6).AEo e DQB1.0302 (DQ8).AEo (CTNBio n 539/2006). Estes camundongos foram gentilmente doados pelo Doutor Chella S. David (Departamento de Imunologia do Colégio Clínico MAYO, Rochester - MN, EUA) e criados em área livre de patógenos específicos (SPF, do inglês "specific pathogen free") no Centro de Bioterismo da Universidade de São Paulo (FMUSP).

Todos os animais estudados tinham idade entre 6 e 8 semanas. A acomodação e a manipulação desses camundongos seguiram condições de assepsia e higiene, sendo mantidos em micro isoladores, alimentados com ração e água autoclavados e manuseados dentro de capelas de segurança biológica, na área SPF do Biotério de Experimentação do Instituto de Medicina Tropical da Universidade de São Paulo (IMT-SP-USP). Os animais foram mantidos e manipulados de acordo com as regras de bem estar animal do Comitê de Ética da universidade de São Paulo.

\section{Validação de transgenia para o gene HLA de classe II humano em camundongos}

\subsection{Coleta de amostras e obtenção de DNA para as tipificações}

Para a certificação da transgenia dos animais, foram coletadas amostras de sangue por punção no plexo retro-orbital dos camundongos, com pipetas Pasteur estéreis embebidas em solução à $25 \mathrm{mM}$ de ácido 
etilenodiaminotetracético (EDTA, Sigma, EUA). As amostras foram acondicionadas em micro tubos de $2 \mathrm{~mL}$ estéreis contendo $50 \mu \mathrm{L}$ de EDTA 25 mM. Em seguida, as amostras passaram por vários ciclos de lise eritrocitária por adição de $2 \mathrm{~mL}$ de tampão tris (hidroximetil) aminometano (tris, Vetec, Brasil) $10 \mathrm{mM}, \mathrm{pH}$ 7.5, contendo cloreto de magnésio $5 \mathrm{mM}$ (Merck, Alemanha) e cloreto de sódio 10 mM (Synth, Brasil) (tampão SLE). Após homogeneização por inversão, os tubos foram mantidos em repouso no gelo por 30 minutos e centrifugados a $375 \mathrm{xg}$ durante 10 minutos a $4^{\circ} \mathrm{C}$, o sobrenadante foi desprezado ao término do ciclo, que foi repetido até a obtenção de um botão de sedimentação claro com ausência de eritrócitos.

Para a ruptura da membrana nuclear, desproteinização e obtenção do DNA, adicionou-se $500 \mu \mathrm{L}$ de tampão denominado SLGB, que consiste em solução de tris a $10 \mathrm{mM}$, pH 6.0, acrescido de $10 \mathrm{mM}$ de EDTA, $50 \mathrm{mM}$ de cloreto de sódio, 0,2\% (p/v) de sódio dodecil sulfato (SDS, Gibco, EUA) (tampão SLGB) e $0,08 \mathrm{mg} / \mathrm{mL}$ de proteinase $\mathrm{K}$ (Invitrogen, EUA). Após homogeneização dos tubos, por inversão, seguido de incubação em Banho Maria a $55^{\circ} \mathrm{C}$ por 3 horas, foram adicionados $400 \mu \mathrm{L}$ da mistura de fenol/clorofórmio/álcool isoamílico (Invitrogen, EUA) na proporção de 24:24:1, respectivamente. Os tubos foram novamente homogeneizados por inversão e centrifugados a $210 \mathrm{xg}$ durante 10 minutos a $4^{\circ} \mathrm{C}$. O sobrenadante foi transferido para um novo micro tubo de $2 \mathrm{~mL}$ onde foi adicionado $300 \mu \mathrm{L}$ de clorofórmio/álcool isoamílico na proporção $24: 1$, respectivamente. Os tubos foram homogeneizados por inversão e centrifugados a $210 x g$ por 10 minutos a $4^{\circ} \mathrm{C}$. O sobrenadante foi transferido para um novo micro tubo cônico de $1,5 \mathrm{~mL}$ onde se adicionou $20 \mu \mathrm{L}$ de acetato de sódio $3 \mathrm{M}$ e $1 \mathrm{~mL}$ de etanol absoluto 
gelado. Após incubação por 15 minutos à $-70^{\circ} \mathrm{C}$ os tubos foram centrifugados a 470xg durante 15 minutos a $4^{\circ} \mathrm{C}$. Os sedimentos obtidos foram ressuspensos em $700 \mu \mathrm{L}$ de etanol $70 \%$ gelado e centrifugados a $470 x g$ por 5 minutos a $4^{\circ} \mathrm{C}$. Após a secagem do botão de sedimentação, os mesmos foram diluídos em 50 $\mu L$ de água estéril.

\subsection{Amplificação de transgene pelo método de PCR-SSP}

Os genes de interesse foram amplificados utilizando-se seqüências iniciadoras (“primers”, Invitrogen, EUA) específicas para cada gene, sendo elas:

DR4: Fw...5 '...gtt tct tgg agc agg tta aac a...3'

$\mathrm{Rv} . .5^{\prime}$...ctg cac tgt gaa get ctc ac...3'

DR2: Fw...5' ...tcg ccg ctg cac tgt gaa g...3'

Rv...5'...tcc tgt ggc agc cta aga g...3'

DQ6: Fw...5' ...agg att tcg tgc tcc agt tta agg cca tg...3'

Rv...5'...tct gca aga tcc cgc gga acg cc...3'

DQ8: Fw...5' ...agg att tgg tgt wcc agt tta agg gca t...3'

Rv...5' ...tgc aag gtc gtg cgg agc tcc aa...3'

As seqüências iniciadoras foram diluídas, aliquotadas e estocadas a $-20^{\circ} \mathrm{C}$ em uma concentração de 12.5 pM/ $\mu \mathrm{L}$, concentração ideal para o uso. 


\subsection{Amplificação dos genes}

Para 1,0 $\mu \mathrm{L}$ de DNA de amostra em estudo, adicionou-se $0,2 \mathrm{mM}$ de deoxinucleotideos trifosfatados (dNTP), 1,0 mM de tampão de amplificação (Buffer, LGC Biotecnologia, Brasil), que consiste em 0,5 mM de cloreto de magnésio, 3,12 pM de cada seqüência iniciadora, 1,0 U de enzima Taq DNA polimerase (LGC Biotecnologia, Brasil) e água estéril, para completar um volume final de $25 \mu \mathrm{L}$. Todo o procedimento foi efetuado em condições de esterilidade em capela de segurança biológica.

As amostras foram acondicionadas à termocicladores (MJ-research, EUA) e submetidas a uma temperatura de $95^{\circ} \mathrm{C}$ durante 7 minutos para promover a denaturação da dupla fita de DNA. Após esse período foram realizados 35 ciclos de 1 minuto e meio divididos em 3 fases com: 30 segundos a $95^{\circ} \mathrm{C}$ para a denaturação, 30 segundos a $55^{\circ} \mathrm{C}$ para promover o anelamento das seqüências iniciadoras e 30 segundos a $72^{\circ} \mathrm{C}$ onde ocorreu a extensão das seqüências iniciadoras e ligação dos deoxinucleotideos correspondentes à fita molde de DNA.

Ao término dos ciclos, as amostras foram incubadas por 7 minutos a $72^{\circ} \mathrm{C}$ e depois mantidas a $4^{\circ} \mathrm{C}$ até a sua retirada, assegurando assim a eficácia do programa.

\subsection{Eletroforese}

Os produtos da amplificação foram diluídos em tampão de corrida (Blue Juice, Invitrogen, EUA) e aplicados em gel de agarose a $3 \%(p / v)$ (Invitrogen, EUA), acrescido de $0,5 \mu \mathrm{L} / \mathrm{mL}$ final de brometo de etídeo 
(Invitrogen, EUA). Para a análise e controle das bandas obtidas aplicou-se amostra padrão de pares de base (Ladder 100 pb, Invitrogen, EUA). O gel foi submetido a uma tensão de 180 Volts durante 45 minutos, em tampão TAE, que consiste em solução de tris 40 mM, acrescido de 4 M de EDTA, pH 8,0 e ácido acético glacial (Merck, Alemanha), promovendo assim migração do DNA. Em seguida o gel foi visualizado em um trans-iluminador (Alphalmager, EUA), onde pode se constatar a presença das bandas com tamanhos correspondentes às seqüências em estudo, validando assim as amostras como positivas para a presença do transgene.

\section{Avaliação da expressão de moléculas de HLA de classe II na superfície celular por citometria de fluxo}

Para determinar a presença de moléculas HLA de classe II, na superfície das células mononucleares do sangue periférico, dos camundongos transgênicos, foi utilizada a técnica de citometria de fluxo. Amostras de sangue dos camundongos foram obtidas, na presença de solução a $25 \mathrm{mM}$ EDTA e $100 \mu \mathrm{L}$ destas amostras foram utilizadas para reações com os anticorpos, anti-CD11c de camundongo marcado com aloficocianina (APC) diluído a 1:50 (v/v) (BD Pharmigen, EUA), anti-CD45/B220 de camundongo marcado com proteína clorofila peridinina (PercP) diluído a 1:200 (v/v) (BD Pharmigen, EUA), anti-DR (humano) marcado com isotiocianato de fluoresceína (FITC) diluído a 1:10 (v/v) (BD Pharmigen, EUA), para as amostras de sangue dos camundongos DR2 e DR4. Todos os anticorpos foram diluídos em tampão de FACS, que contém 0,81\% (p/v) de cloreto de sódio (VETEC, Brasil), 0,028\% 
$(\mathrm{p} / \mathrm{v})$ de cloreto de potássio (VETEC, Brasil), 0,026\% (p/v) de fosfato de sódio monobásico, 0,23\% (p/v) de fosfato bibásico de sódio (MERCK, Alemanha), 0,043\% de cloreto de lítio (Synth, Brasil), 0,036\% de EDTA sódico (Gibco, EUA) e 0,02\% de azida sódica (Synth, Brasil). Essas amostras foram então incubadas durante 30 minutos em câmara escura à temperatura ambiente. No caso dos camundongos DQ6 e DQ8 foi realizada uma incubação prévia com anti-DQ, diluído a 1:5000 (v/v), por 30 minutos à temperatura ambiente, após esse período foram realizadas 3 lavagens por centrifugação a $375 \times$ g por 5 minutos a $4^{\circ} \mathrm{C}$ com tampão de FACS.

As amostras desses animais foram incubadas com os mesmos anticorpos descritos anteriormente para a detecção de CD11c e CD45/B220, além de anti-lg de camundongo conjugado à FITC, diluído a 1:400 (v/v) (BD Pharmigen, EUA) durante 30 minutos em câmara escura à temperatura ambiente. Ao término do período de incubação foi adicionado $2 \mathrm{~mL}$ de tampão de lise de eritrócitos/tubo (Lysing Solution, BD FACS, EUA) e mantidos por 10 minutos em câmara escura à temperatura ambiente. As amostras foram lavadas por 3 vezes, por centrifugação a $375 x$ durante 5 minutos a $4^{\circ} \mathrm{C}$, com tampão de FACS e então ressuspensas em $400 \mu \mathrm{L}$ desse mesmo tampão para serem analisadas em citômetro de fluxo.

Para comprovar a inexistência de MHC-II murino foi realizado o mesmo protocolo para obtenção de células mononucleares de sangue periférico e marcação com anticorpos, sendo que foram utilizados anticorpos anti-I/A e I/E (murinos) marcados com ficoeritrina (PE) diluídos a 1:200 (v/v, BD Pharmigen, EUA) e os mesmos anticorpos usados anteriormente (anti-lg e anti-DR FITC), nas mesmas condições. Nos experimentos de detecção de 
MHC-II foram utilizados como controles células de sangue periférico de camundongos BALB/c, sangue humano e células de linhagens imortalizadas pelo vírus Epstein Barr.

As amostras foram estudadas em citômetro de fluxo BD FACSCanto ${ }^{\mathrm{TM}}$ (BD Bio-Sciences, San Jose, CA, EUA) e os dados gerados foram analisados no programa FlowJo (Tree Star Inc., Oregon, EUA).

\section{Antígenos}

O agente vacinal StreptInCor, na forma de peptídeo sintético de 55 aminoácidos, correspondente a uma fração da região C-terminal da proteína M5 (Robinson et al, 1991) do Streptococcus pyogenes foi produzido na unidade de síntese de peptídeos, do Laboratório de Imunologia do InCor. O StreptInCor foi diluído em dimetilsulfoxido (DMSO, Merck) à uma concentração de 50 $\mathrm{mg} / \mathrm{mL}$ (solução mãe). Proteína $M 1$ recombinante de cepa reumatogênica do $S$. pyogenes foi produzida em nosso laboratório. Miosina cardíaca porcina e ovalvumina (OVA) foram obtidas da Sigma (EUA).

\section{Imunizações}

Em todas as imunizações realizadas neste trabalho, foi utilizada a via sub-cutânea de inoculação, na região dorsal dos camundongos, quando empregado o hidróxido de alumínio $\left[\mathrm{Al}(\mathrm{OH})_{3}\right]$ como adjuvante e nas patas traseiras (50 $\mu \mathrm{l} /$ pata) quando empregado o adjuvante de Freund. Após utilizar as vias sub-cutânea, intra-muscular e intra-peritonial e constatar que não houve diferença na resposta imunológica encontrada nas imunizações com $\mathrm{Al}(\mathrm{OH})_{3}$, 
optou-se pela via que apresentava fácil acesso e menor período de manipulação do animal.

A concentração do StreptInCor utilizada em todos os experimentos mostrados aqui foi de $50 \mu \mathrm{g} / \mathrm{mL}$, a qual representou uma resposta mais homogênea entre os animais imunizados, sendo semelhante àquelas encontradas nos animais convencionais. Essa concentração foi determinada por uma cinética de dose-resposta utilizando as quatro linhagens de camundongos transgênicos.

\subsection{Imunizações com hidróxido de alumínio}

Duas doses com $50 \mu \mathrm{g}$ do peptídeo StreptInCor na presença de 300 $\mu \mathrm{g}$ de hidróxido de alumínio (Sigma, EUA) em volume final de $100 \mu \mathrm{L}$ por camundongo foram administrados, com intervalo de 14 dias entre elas. Em todos os ensaios experimentais, em que foi empregado o StreptInCor como imunógeno, foram realizadas imunizações em grupos controles que receberam somente o veículo (salina estéril, Baxter, EUA), com hidróxido de alumínio, nas mesmas condições dos grupos experimentais que receberam o peptídeo. Como controle positivo de resposta, um único lote de camundongos foi imunizado com ovalbumina, adsorvida em hidróxido de alumínio. Em todas as imunizações, em que foi empregado o hidróxido de alumínio como adjuvante, foi utilizada a via subcutânea para a inoculação.

Após 14 dias da última dose, amostras de soro foram obtidas, a partir da coleta de sangue por punção do plexo retro-orbital com pipetas Pasteur, e foram acondicionados a $-20^{\circ} \mathrm{C}$ até o momento de sua utilização. Para um 
estudo da durabilidade da resposta imune humoral, adicionalmente, lotes de animais imunizados com StreptInCor foram acompanhados por 12 meses após a última imunização.

\subsection{Imunizações com adjuvante de Freund}

Os animais foram imunizados com $50 \mu \mathrm{g}$ do StreptlnCor, diluídos $\mathrm{v} / \mathrm{v}$ em adjuvante completo de Freund (ACF, Sigma, EUA), após 14 dias esse mesmo grupo recebeu mais uma dose da mesma concentração do agente vacinal na presença de adjuvante incompleto de Freund (AIF, Sigma, EUA), Os grupos controles receberam somente o veículo (salina estéril); com adjuvante de Freund (completo e incompleto) nas mesmas condições dos grupos experimentais que receberam o peptídeo. Após 14 dias da última dose, amostras de soro foram obtidas, a partir da coleta de sangue por punção do plexo retro-orbital com pipetas Pasteur, e foram acondicionados a $-20^{\circ} \mathrm{C}$ até o momento de sua utilização.

\section{Avaliação da resposta imune humoral por ELISA}

Placas de poliestireno de alta ligação com 96 poços (Costar Corning modelo 3369, EUA) foram sensibilizadas com $1 \mu \mathrm{g} /$ poço dos seguintes antígenos: StreptInCor, miosina cardíaca, ovalbumina ou proteína M1 recombinante. Todos os antígenos foram diluídos em tampão carbonato/bicarbonato de sódio $0,05 \mathrm{M}, \mathrm{pH} 9,6$ e mantidas por 16 horas a $4^{\circ} \mathrm{C}$.

Para o controle das reações inespecíficas, placas contendo gelatina (Sigma, EUA), também foram empregadas. 
Após a sensibilização das placas, efetuou-se o bloqueio dos sítios remanescentes do plástico, por 1 hora a temperatura ambiente, com a adição de $200 \mu \mathrm{L} /$ poço de salina tamponada com fosfato (PBS), acrescida de $0,25 \%$ $(\mathrm{p} / \mathrm{v})$ de gelatina e $0,05 \%(\mathrm{v} / \mathrm{v})$ de Tween 20 (Merck, EUA) (PBS-T-G). Em seguida, as placas foram incubadas com diluições seriadas dos soros dos camundongos (1:100 até 1:12800), num volume de $50 \mu \mathrm{L} /$ poço, em PBS-T-G. Após incubação por 2 horas a $37^{\circ} \mathrm{C}$, as placas foram lavadas 3 vezes com PBS acrescido de 0,05\% (v/v) de Tween 20 (PBS-T) e incubadas com 50 $\mathrm{LL} /$ poço do anticorpo anti-lgG de camundongo, conjugado à peroxidase (Sigma), diluído a 1:4000 em PBS-T-G. Uma nova incubação de 1 hora a $37^{\circ} \mathrm{C}$ seguida por 3 lavagens com PBS-T-G, precedeu a revelação do ensaio, colocando-se 50 $\mu \mathrm{L} /$ poço de solução contendo $0.4 \mathrm{mg} / \mathrm{mL}(\mathrm{p} / \mathrm{v})$ de orto-fenileno-diamina (OPD, Sigma, EUA) em tampão citrato/fosfato $\mathrm{pH} 5,0$ acrescido de $0,04 \%$ (v/v) de peróxido de hidrogênio. Após 10 minutos a reação foi bloqueada com a adição de $50 \mu \mathrm{L} /$ poço de ácido sulfúrico $2 \mathrm{M}$.

A reação colorimétrica foi então quantificada por espectrometria a 490 $\mathrm{nm}$ de comprimento de onda, em um leitor de microplacas (Biotek, Winooski, EUA) e as densidades ópticas (D.O.) foram obtidas pelo software KC Junior da Biotek (Winooski, EUA).

As curvas individuais de cada soro foram obtidas e, a partir destas, os títulos referentes a cada animal. Para tal, consideramos a diluição do soro que induziu uma D.O. maior que o valor observado para a média do controle negativo (soros pré-imunes) mais dois desvios padrão, referente ao título de anticorpos para a mesma amostra. 
Para a dosagem de isotipos, o protocolo experimental foi semelhante ao descrito acima, porém com uma etapa adicional. Utilizamos os conjugados biotinilados dirigidos contra os anticorpos de camundongo (lgG1, $\lg G 2 a, \lg G 2 b$ e IgG3, BD Pharmigen, EUA), na concentração de $2 \mu \mathrm{g} / \mathrm{mL}$. Seguindo-se uma incubação de uma hora a $37^{\circ} \mathrm{C}$ e três lavagens com PBS-T-G (200 $\mu \mathrm{L} /$ poço), adicionou-se $50 \mu \mathrm{L} /$ poço de solução de estreptavidina conjugada a peroxidase, diluída a 1:1000 (BD Pharmigen, EUA). Após nova incubação de uma hora a $37^{\circ} \mathrm{C}$, as reações foram reveladas como descrito anteriormente.

\section{Avaliação da resposta imune celular}

\subsection{Obtenção de células mononucleares de camundongos}

Todo o procedimento foi realizado sob condições de assepsia, utilizando-se material estéril, em capela de segurança biológica. Células mononucleares provenientes dos baços dos camundongos imunizados foram obtidas após maceração gentil dos órgãos e lavadas, por centrifugação (210xg a $4^{\circ} \mathrm{C}$, por 10 minutos) com $10 \mathrm{~mL}$ de meio RPMI 1640 (Sigma, EUA), suplementado com L-glutamina 2 mM (Sigma, EUA), Hepes 10 mM (Sigma, EUA) e os antibióticos Gentamicina $(40 \mu \mathrm{g} / \mathrm{mL})$ e Peflacin $(20 \mu \mathrm{g} / \mathrm{mL})$. Após a lavagem, as células foram ressuspensas em meio R5, que consiste no meio RPMI suplementado, acrescido de 5\% (v/v) de soro fetal bovino (SFB, GIBCO, EUA), e utilizado nos experimentos de proliferação celular. 


\subsection{Ensaio de proliferação celular por citometria de fluxo (CFSE)}

Os esplenócitos dos camundongos imunizados com o StreptInCor e controles foram centrifugados a 350xg por 6 minutos à uma temperatura de $4^{\circ} \mathrm{C}$, os sobrenadantes foram desprezados e os botões de sedimento ressuspensos em $1 \mathrm{~mL}$ de $\mathrm{ACK}$, que consiste em solução contendo 0,15 M de cloreto de amônio, acrescido de $1 \mathrm{mM}$ de bicarbonato de potássio e $0,1 \mathrm{mM}$ de EDTA dissódico (Gibco, EUA). Após uma incubação de 2 minutos foram efetuadas duas lavagens completando o volume da amostra para $15 \mathrm{~mL}$ de meio RPMI suplementado e centrifugando a $350 x g$ por 6 minutos a $4^{\circ} \mathrm{C}$. A contagem das células foi feita, em câmara de Neubauer por uma diluição primária (1/10) com meio RPMI suplementado, acrescido de $10 \%(\mathrm{v} / \mathrm{v})$ de soro fetal bovino (denominado R10), e posterior diluição secundária contendo $65 \mu \mathrm{L}$ de R10 (meio RPMI contendo $10 \%$ de soro fetal bovino) $+25 \mu \mathrm{L}$ de trypan blue (Gibco, EUA $)+10 \mu \mathrm{L}$ da diluição primária.

Uma suspensão celular contendo $5 \times 10^{7}$ esplenócitos em um volume final de $1 \mathrm{~mL}$ de PBS pré aquecido, acrescido de 1,25 $\mu \mathrm{M}$ de CFSE, foi incubada em Banho Maria a $37^{\circ} \mathrm{C}$ por 10 minutos. Após três lavagens por centrifugação a 350xg com $5 \mathrm{~mL}$ de meio R10, as células foram ressuspensas em $1 \mathrm{~mL}$ do mesmo meio, efetuando-se contagem das mesmas. As células foram distribuídas, em triplicatas, em uma placa com fundo em "U" (NUNC, EUA) na concentração de $3 \times 10^{5}$ mil células/poço em um volume final de $200 \mu \mathrm{L}$ (concentração de $1,5 \times 10^{6}$ células $/ \mathrm{mL}$ ) e foram incubadas por cinco dias, na presença de $10 \mu \mathrm{g}$ e $50 \mu \mathrm{g}$ do StreptlnCor ou somente o meio (controle negativo) e 2,5 $\mu \mathrm{g} / \mathrm{mL}$ de concavalina-A (Con-A, Sigma, EUA), como controle positivo, em estufa a $37^{\circ} \mathrm{C}$ contendo atmosfera úmida de $5 \%$ de $\mathrm{CO}_{2}$. 
As triplicatas foram lavadas, por centrifugação a 350xg, com tampão de FACs, que contém $0,5 \%(\mathrm{p} / \mathrm{v})$ de BSA e $2 \mathrm{mM}$ de EDTA e marcadas com um painel de anticorpos da BD Pharmingen (San Jose, CA, EUA), contendo antiCD3 marcado com ficoeritrina (PE) na diluição 1:50, anti-CD4 marcado com proteína clorofila peridina (PercP) na diluição 1:200 e anti-CD8 marcado com aloficocianina (APC) em um volume final de $50 \mu \mathrm{L}$. As amostras foram incubadas com o painel acima por 45 minutos, em câmara escura, em banho de gelo. Após esse período as amostras foram lavadas três vezes, por centrifugação a $350 \mathrm{xg}$, a $4^{\circ} \mathrm{C}$ por 10 minutos, em tampão de FACs para eliminar os anticorpos que não se ligaram aos seus sítios específicos. Finalmente, as amostras foram fixadas, incubando-as com $1 \mathrm{~mL}$ de paraformaldeído, por 5 minutos à temperatura ambiente, seguindo-se nova lavagem nas mesmas condições. Para o estudo em citômetro de fluxo, as células foram ressuspensas em $1 \mathrm{~mL}$ de tampão de FACs. Para a análise do padrão de células de memória, após a proliferação celular, foi utilizado o mesmo protocolo alterando-se o painel de anticorpos da BD Pharmingem, que foi composto pelos anticorpos anti-CD44 marcado com PE, na diluição 1:200; anti-CD62L marcado com APC, na diluição 1:800; anti-CD3, marcado com aloficocianina-cianina 7 (APC-CY7), na diluição 1:50; anti-CD4 marcado com PercP, na diluição 1:200 e anti-CD8 marcado com com ficoeritrina-cianina 7 (PE-CY7), na diluição 1:200.

A aquisição das amostras foi realizada no BD FACSCanto ${ }^{\mathrm{TM}}$ (BD BioSciences, San Jose, CA, EUA) e os dados gerados foram analisados no programa FlowJo (Tree Star Inc., Oregon, EUA). Os resultados da proliferação celular com CFSE foram analisados separando os leucócitos em um "gate" de 
linfócitos e depois os separando em duas sub-populações quanto à presença de moléculas CD4 ou CD8. Dentro desses "gates" a porcentagem de células T $\mathrm{CD}^{+}{ }^{+} \mathrm{CFSE}^{\text {baixo }}$ ou $\mathrm{CD}^{+} \mathrm{CFSE}^{\text {baixo }}$ dos grupos StreptInCor ou salina foi dividida pela porcentagem média obtidas no controle negativo, sem estímulo, para a obtenção do índice de estimulação (I.E.).

\section{Avaliação histopatológica dos animais imunizados}

Diversos tecidos dos animais imunizados com o StreptlnCor e controles foram retirados após 12 meses da última imunização para a avaliação histopatológica. Para tal, coração, baço, fígado, rins, articulações e cérebro foram retirados dos animais imunizados e controles e embebidos em solução de formaldeído tamponado a $10 \%(\mathrm{v} / \mathrm{v})$ e enviados ao serviço de patologia do InCor. Cortes de $5 \mu \mathrm{m}$ foram corados por Hematoxilina e Eosina (HE), para posterior análise histológica. A avaliação histológica para detecção de possíveis lesões patológicas, decorrentes da FR ou não, foi realizada por um médico anátomo-patologista habilitado, sem o conhecimento da identificação dos animais, e em ordem aleatória.

\section{Análise estatística}

Análise de variância (ANOVA) seguida pelo teste de Dunn, que efetua comparação múltipla, foram utilizados para comparação entre mais de duas variáveis, enquanto que o teste de Wilcoxon foi empregado para a comparação entre dois grupos. Valores de $p<0,05$ foram considerados positivos. Os dados 
foram analisados pelo software GraphPad Prism versão 5.00 para Windows (GraphPad Software, San Diego California USA, www.graphpad.com) 


\section{Resultados}


1. Validação de transgenia para o gene HLA de classe II humano em camundongos

A comprovação da transgenia foi observada pela presença de uma banda de 250 pares de base (pb), correspondente ao segmento do gene que codifica o alelo DR ou DQ específico em conformidade com os "primers" utilizados para as quatro linhagens de camundongos (DR2, DR4, DQ6 e DQ8), e utilizados em nosso experimento, e é mostrada na Figura 1. A ausência dos transgenes de interesse também foi observada durante a seleção dos animais para os experimentos. Este fenômeno pode ser observado na Figura 1 (DR2, DR4 e DQ6, colunas 4, 2 e 3, respectivamente). Somente os animais que apresentaram os transgenes foram utilizados nos experimentos subseqüentes.
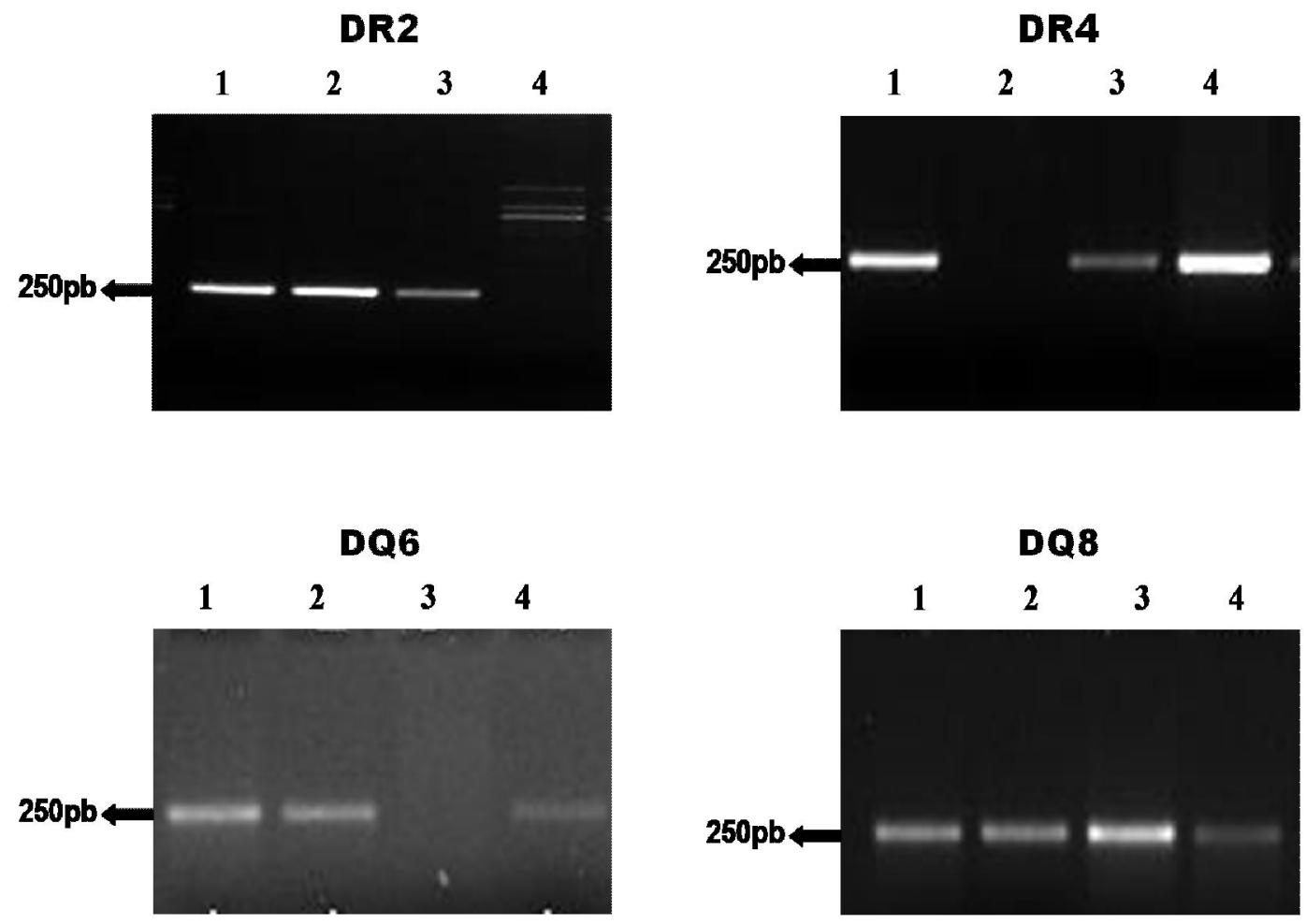

Figura 1. Gel de agarose a $3 \%$, contendo as bandas com pesos moleculares de aproximadamente 250 $\mathrm{pb}$, que representam o produto dos PCR referentes aos transgene. Amostras de quatro camundongos por linhagem (colunas 1 a 4) das linhagens DR2 e DR4, acima; DQ6 e DQ8, abaixo. 


\section{Controle da expressão protéica das moléculas HLA e ausência das moléculas $\mathrm{H}-2$ de classe II na superfície celular}

A presença de moléculas HLA de classe II na superfície de leucócitos dos camundongos estudados foi constatada pela técnica de citometria de fluxo, utilizando anticorpos específicos para as moléculas do complexo principal de histocompatibilidade humano de classe II DR ou DQ, além dos antígenos CD11c e CD45/B220 murinos. Utilizando essas três marcações foi efetuado o ensaio, primeiramente selecionando um "gate" que inclui a população de leucócitos. Neste, as células foram separadas em duas sub-populações conforme sua positividade para CD11c ou CD45/B220 (Figura 2). Essas duas sub-populações foram classificadas conforme sua positividade para DR ou DQ conforme a linhagem de camundongos estudada, onde foi possível mensurar a porcentagem de células $\mathrm{CD} 11 \mathrm{c}^{+}$ou $\mathrm{CD} 45 / \mathrm{B}_{22} \mathrm{O}^{+}$expressando a molécula HLA-II de interesse, descontando os valores obtidos no controle negativo. As Figuras 3 e 4 mostram a porcentagem de células $C D 11 c^{+}$e $C D 45 / B 220^{+}$que expressam a molécula DR enquanto as figuras 5 e 6 mostram a porcentagem de células $C D 11 \mathrm{c}^{+}$e $\mathrm{CD} 45 / \mathrm{B} 220^{+}$que expressam a molécula DQ. Em todas as linhagens estudadas notou-se uma grande variabilidade quanto a expressão das moléculas HLA de classe II (DQ ou DR), apesar da expressão dos transgenes em questão nestes animais. Também observamos que os camundongos da linhagem DR4 apresentaram menor expressão das moléculas trangênicas na superfície das células 

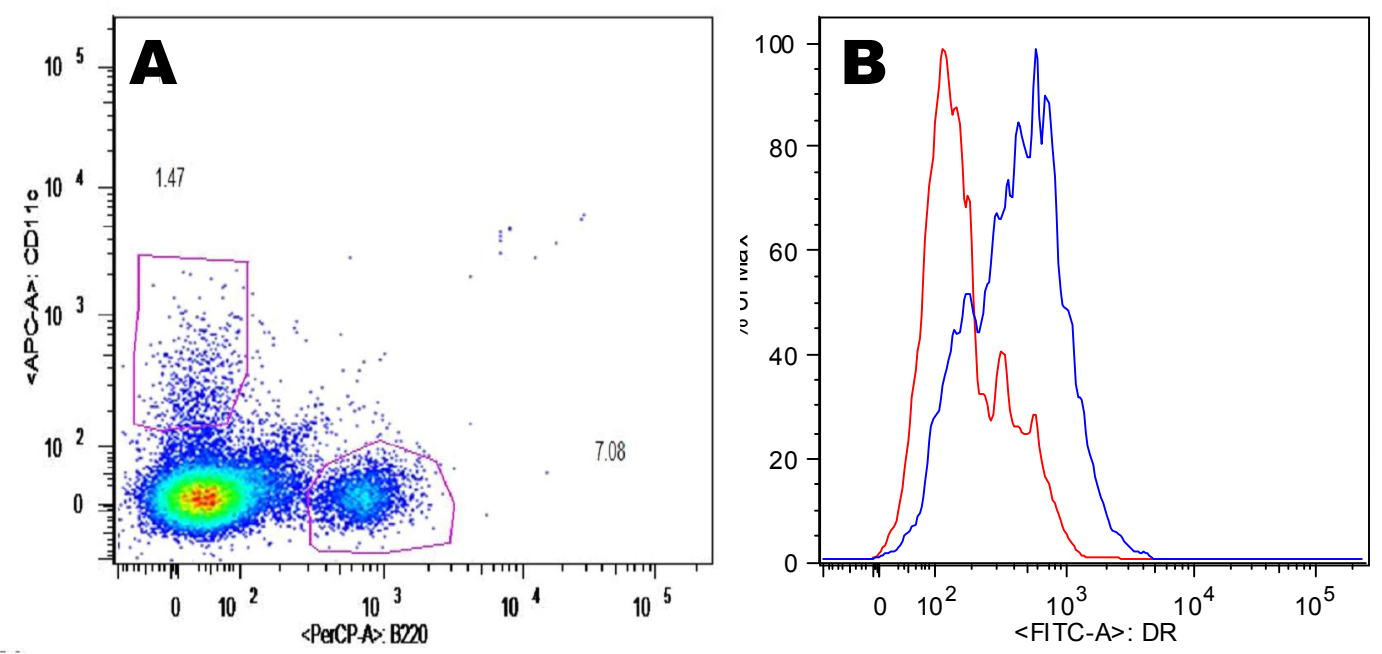

Figura 2. Estratégia de "Gate" no ensaio de citometria de fluxo para a detecção de moléculas HLA-II em leucócitos de camundongos transgênicos. A - Separação de leucócitos em duas sub-populações conforme a presença de CD11c ou CD45/B220; B - Histograma representando a população negativa para a molécula DR (em vermelho) e população positiva para a molécula DR (em azul)

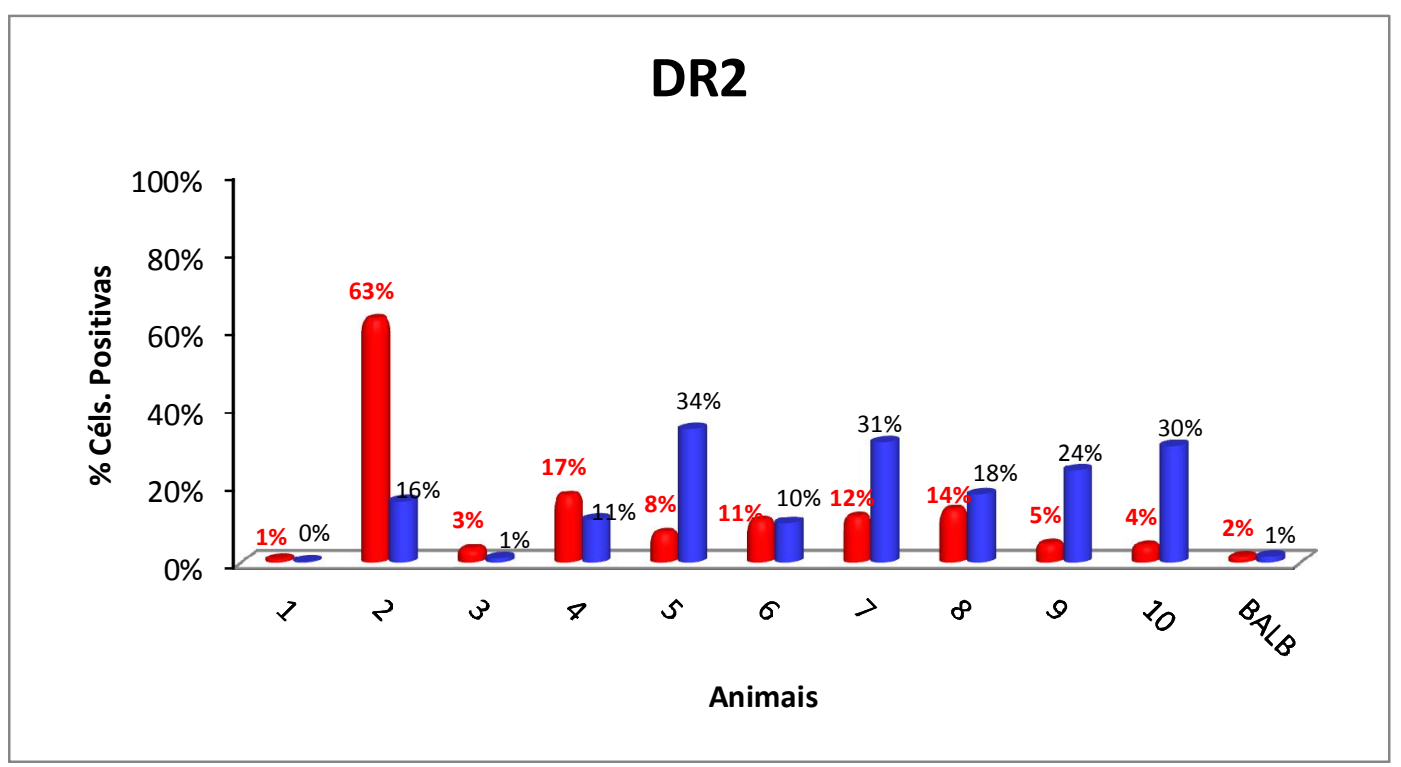

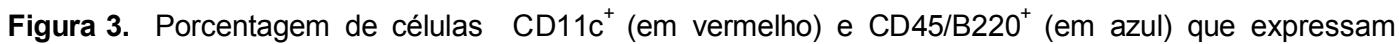
moléculas HLA de classe II DR, no eixo X estão identificados os animais DR2 estudados (1 a 10) e controle negativo (BALB/C). 


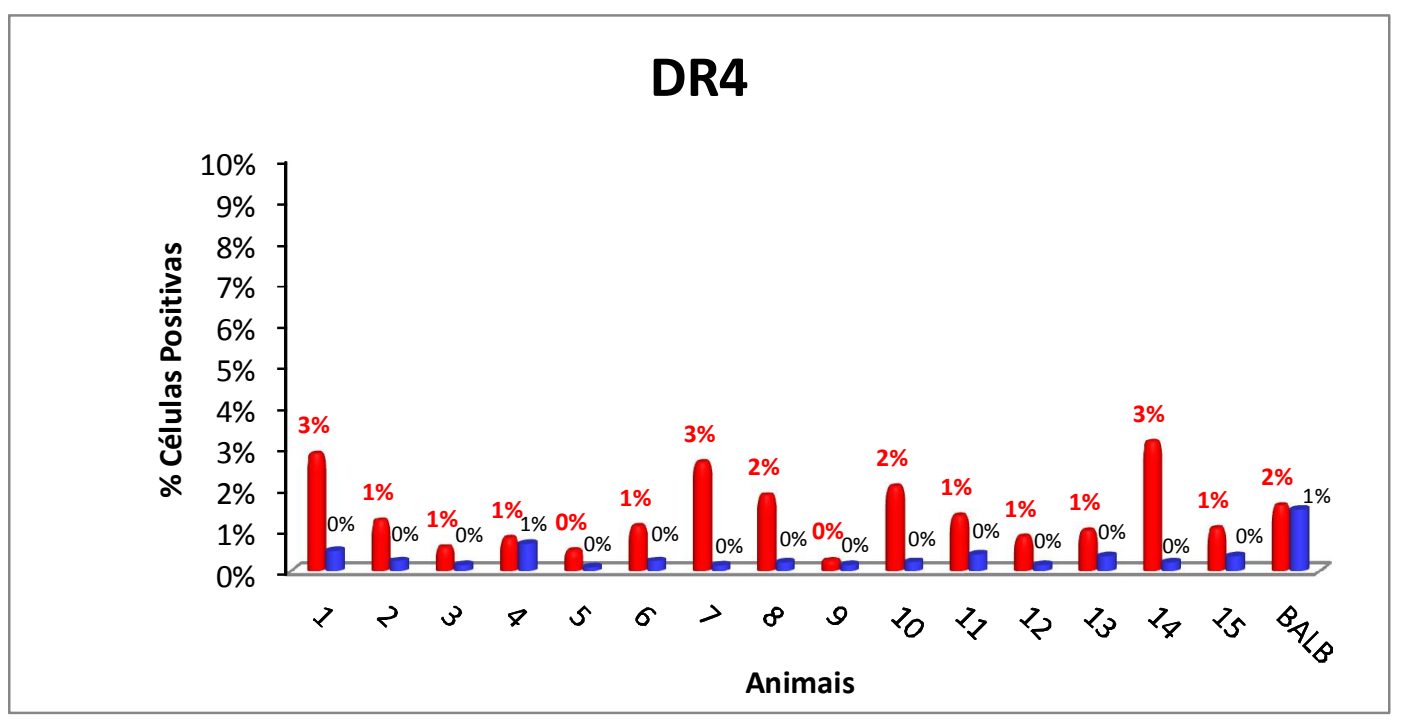

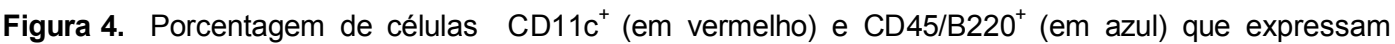
moléculas HLA de classe II DR, no eixo X estão identificados os animais DR4 estudados (1 a 15) e controle negativo (BALB/c).

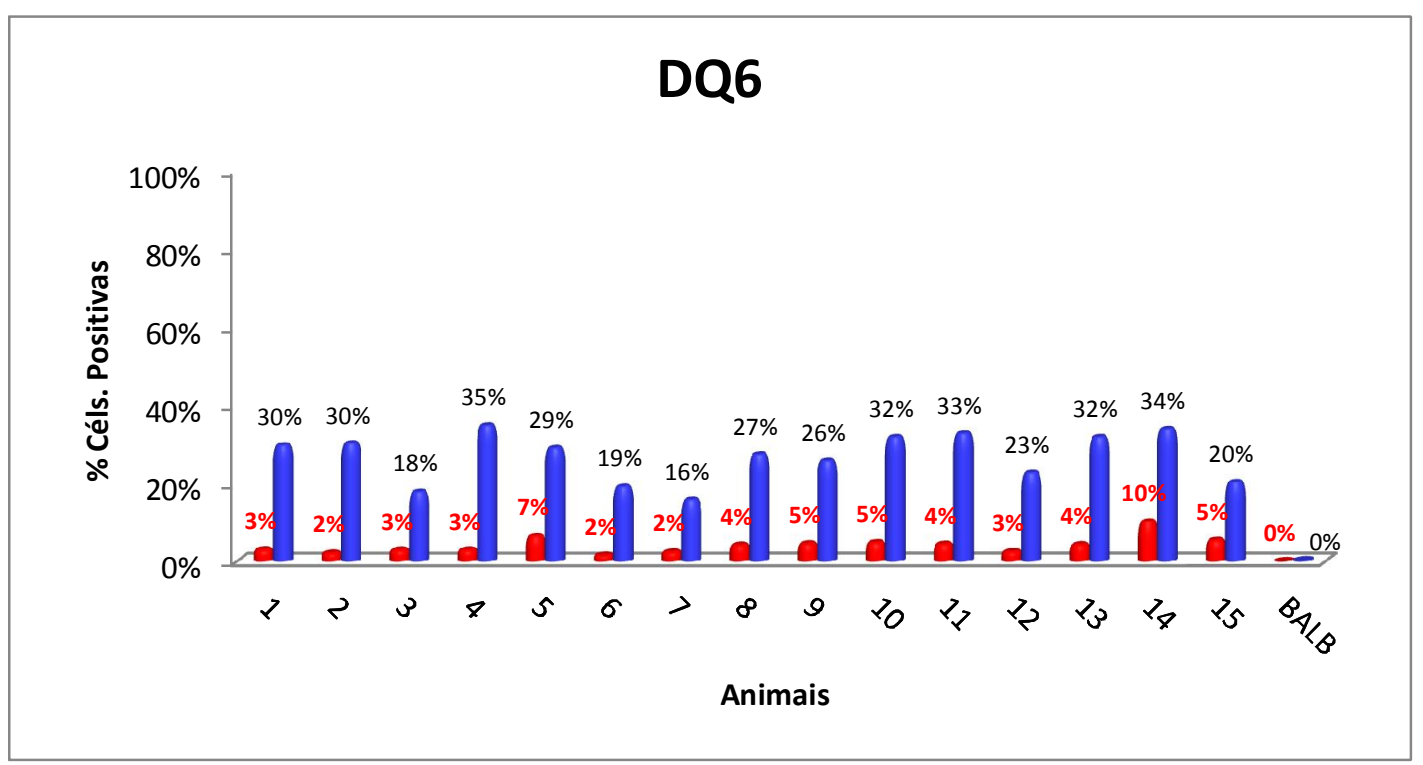

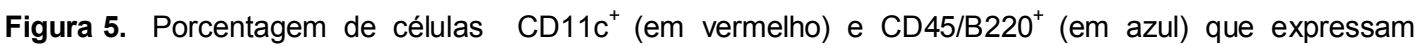
moléculas HLA de classe II DQ, no eixo X estão identificados os animais DQ6 estudados (1 a 15) e controle negativo (BALB/c). 


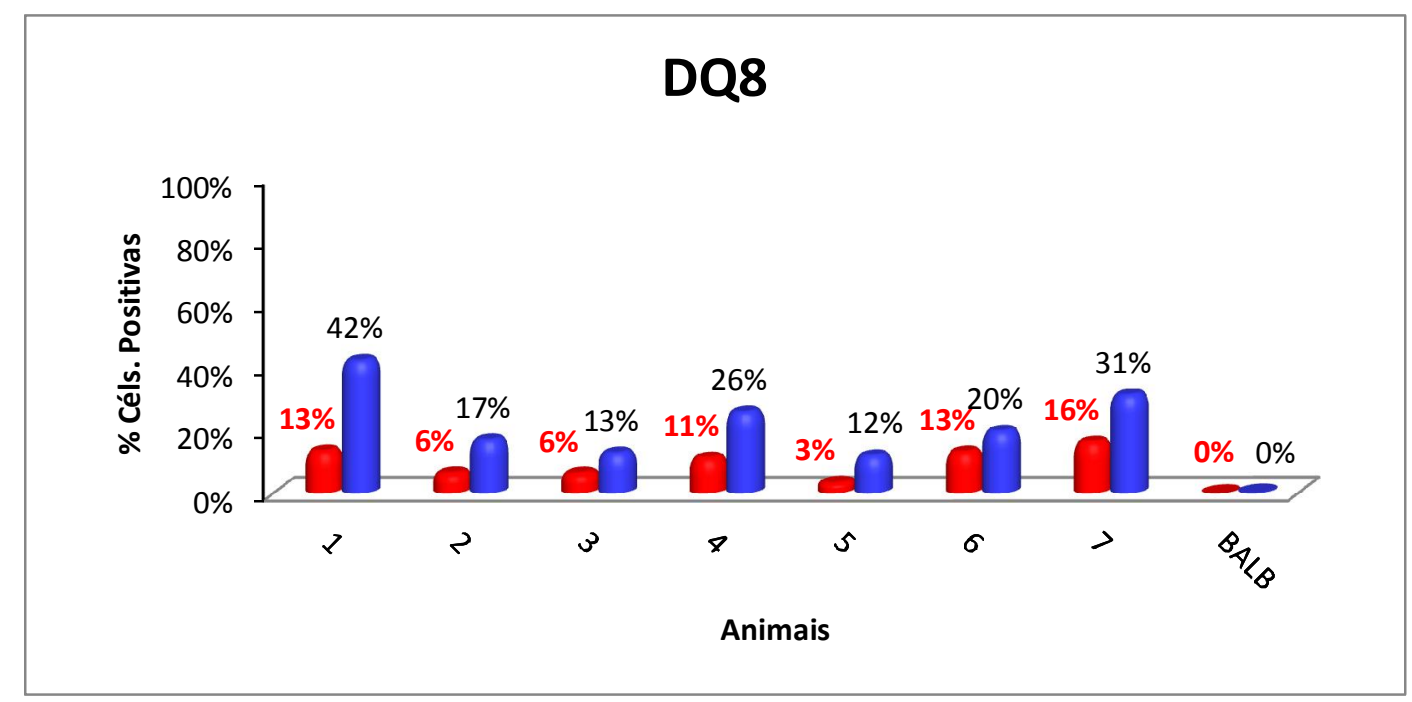

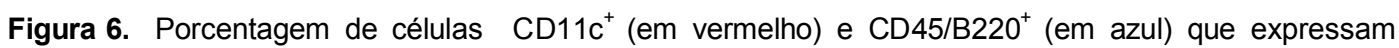
moléculas HLA de classe II DQ, no eixo X estão identificados os animais DQ8 estudados (1 a 7) e controle negativo (BALB/c).

\section{Análise de expressão de MHC-II murino (IA/IE) por citometria de fluxo}

Para comprovar a inexistência de moléculas do complexo principal de histocompatibilidade de classe II murino (IA e IE) ou a possibilidade de formação de moléculas quiméricas de MHC-II, decorrentes de falhas na embriogênese, foi realizada a pesquisa destas moléculas pela técnica de citometria de fluxo utilizando anticorpos específicos às moléculas $H 2$, IA/IE, e HLA-II, DR ou DQ. Utilizando essa dupla marcação foi possível classificar as células em $\mathrm{DR}^{+} / \mathrm{DQ}^{+}$ou $\mathrm{IA}_{\mathrm{IE}}^{+}$. A Figura 7 exemplifica estratégia de "gate" utilizada nesse ensaio.

Como podemos notar nas Figuras 8, 10 e 11 (DR2, DQ6 e DQ8, respectivamente), todos os animais apresentaram as moléculas de HLA de classe II e ausência das moléculas IA/IE (MHC de classe II murino). Entretanto, não detectamos moléculas de classe II (HLA ou IA/IE) entre os animais da linhagem DR4 (Fig. 9). 


\section{HLA x H2}

BALB/c

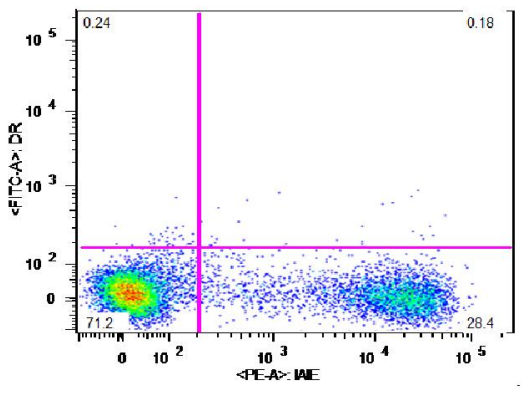

Humano

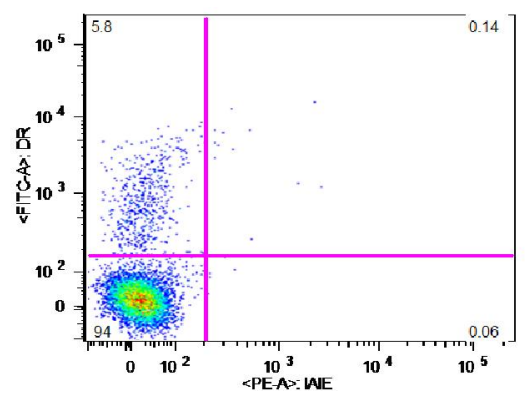

C57BI/6

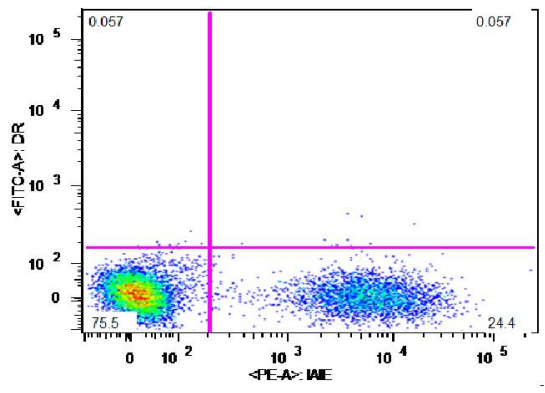

DR2

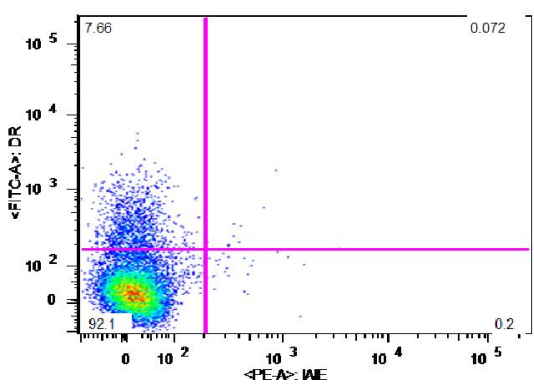

Figura 7. Demonstração de resultados encontrados no experimento de análise de MHC-II. Utilizando uma dupla marcação foi possível diferenciar células DR ou DQ positivas de células IA/IE positivas. A figura mostra nos quadrantes superiores a presença, apenas, de moléculas IA/IE em camundongos convencionais e nos quadrantes inferiores a presença, apenas, de moléculas DR em humanos e nos camundongos utilizados em nosso estudo.

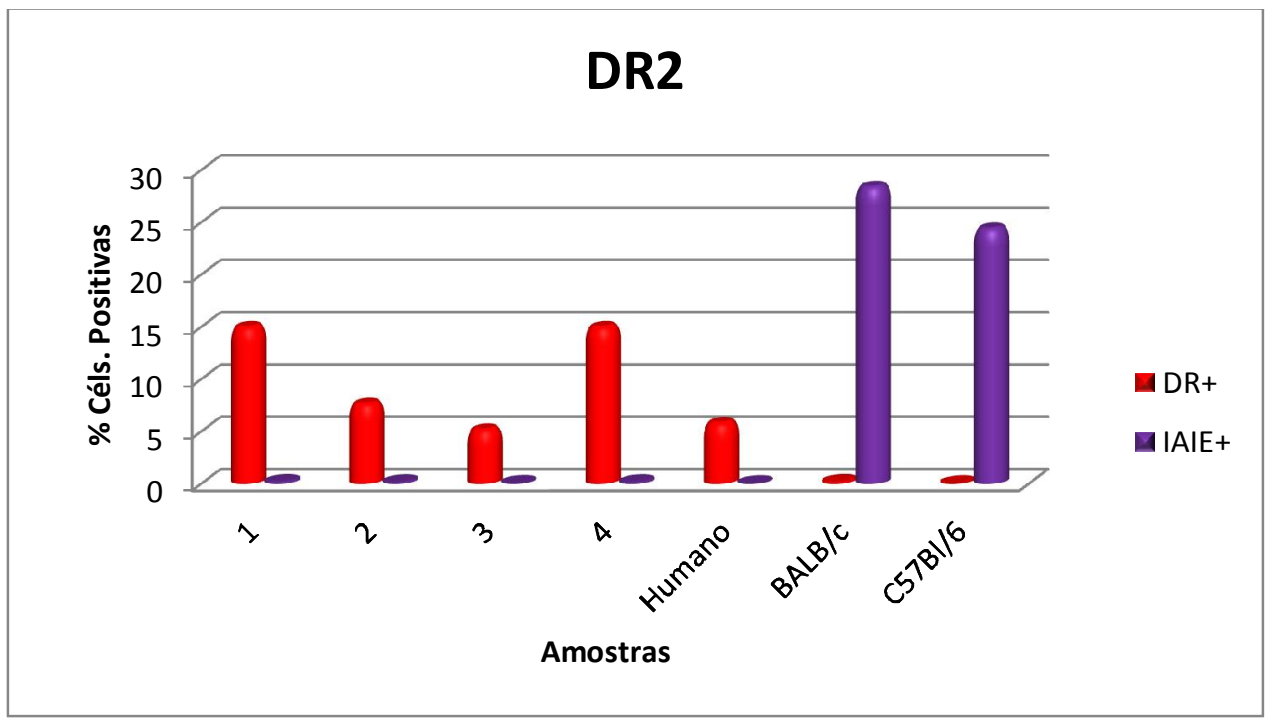

Figura 8. Presença de moléculas MHC de classe II DR (Humanas) e/ou IAIE (Murinas) em camundongos positivos para o gene DR2 e controles murino (BALB/c e C57BI/6) e humano. 


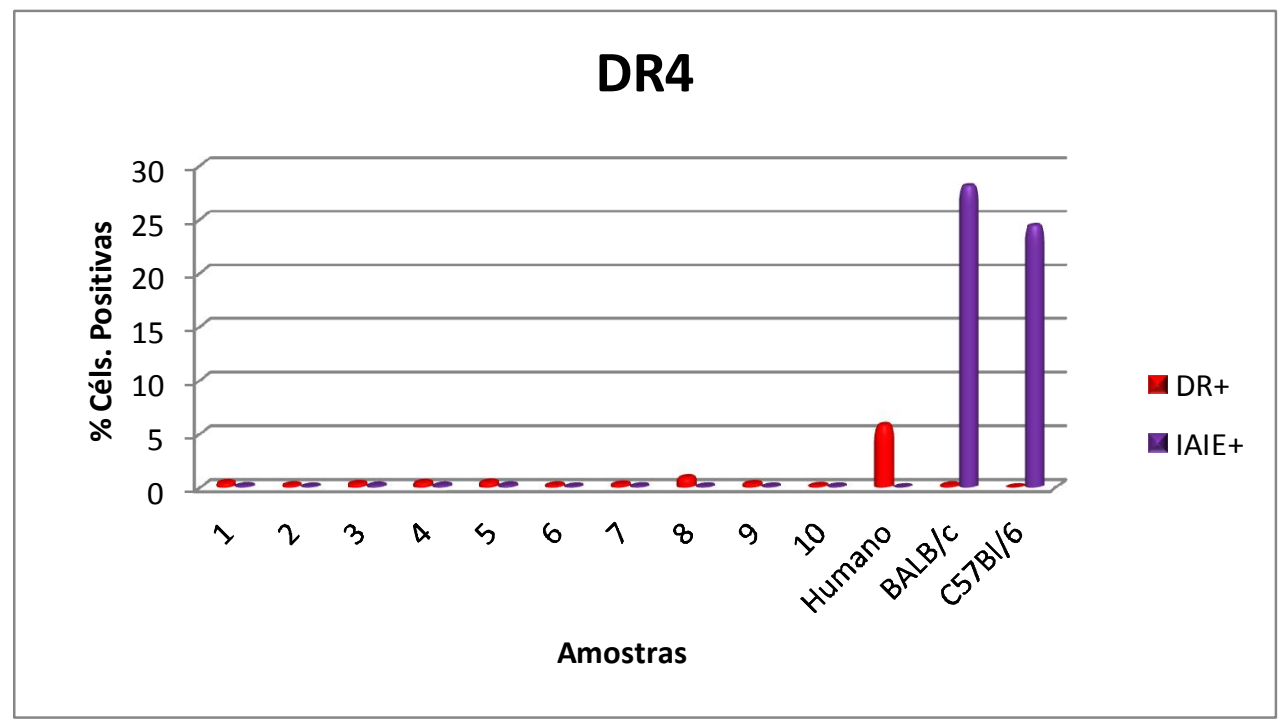

Figura 9. Presença de moléculas MHC de classe II DR (Humanas) e/ou IA/IE (Murinas) em camundongos positivos para o gene DR4 e controles murino (BALB/c e C57BI/6) e humano.

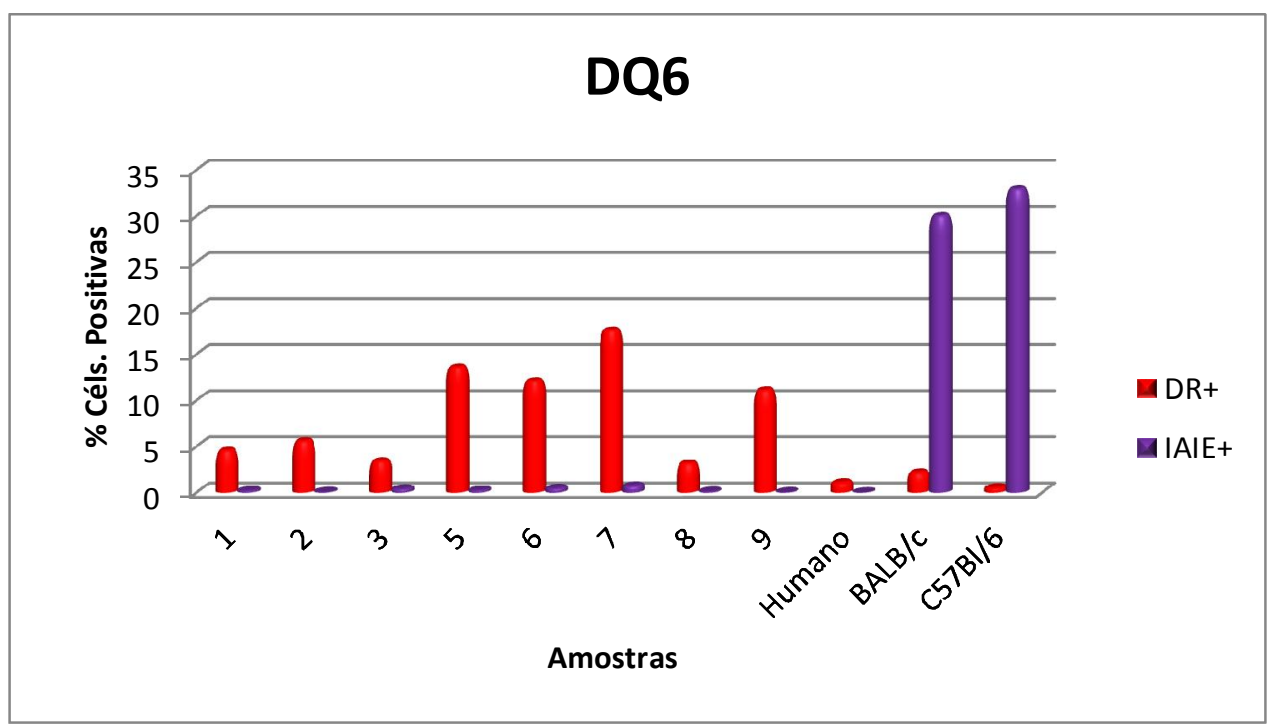

Figura 10. Presença de moléculas MHC de classe II DQ (Humanas) e/ou IA/IE (Murinas) em camundongos positivos para o gene DQ6 e controles murino (BALB/c e C57BI/6) e humano. 


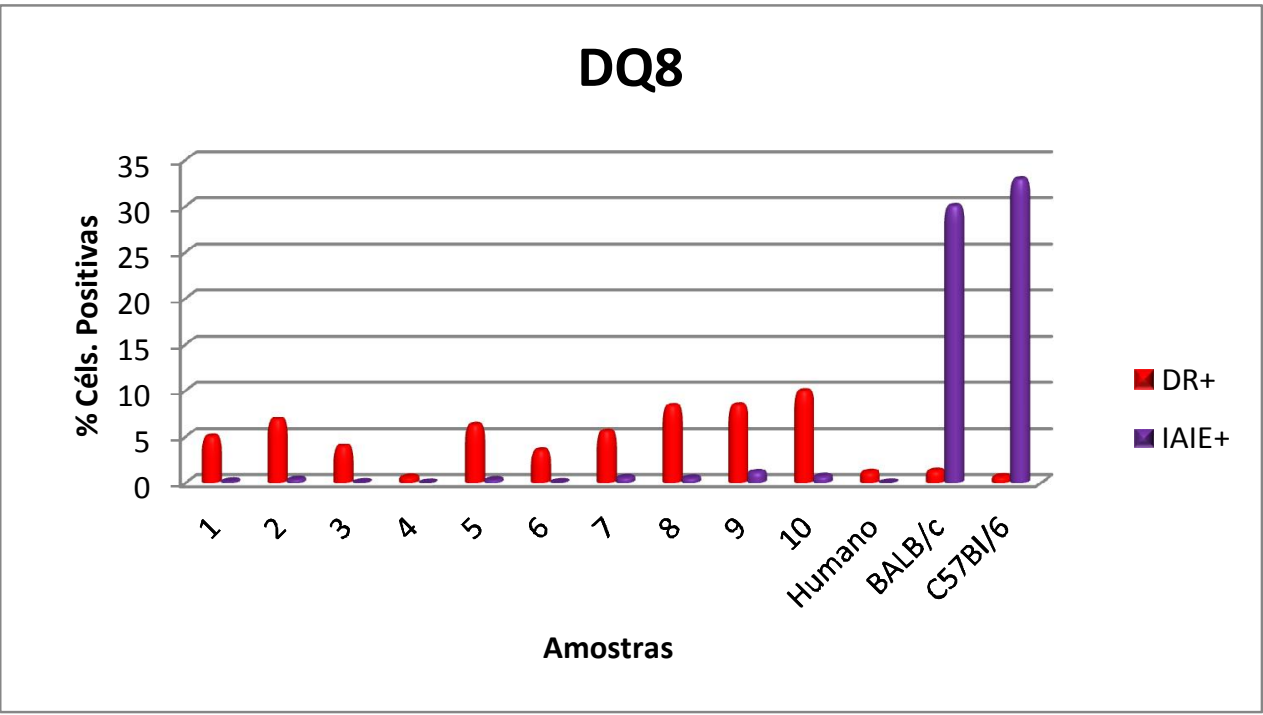

Figura 11. Presença de moléculas $M H C$ de classe II DQ (Humanas) e/ou IA/IE (Murinas) em camundongos positivos para o gene DQ8 e controles murino (BALB/c e C57BI/6) e humano.

\section{Resposta humoral dos camundongos imunizados com 0 agente} vacinal e controles ao StreptInCor

Imunizações com duas doses de $50 \mu \mathrm{g}$ do StreptlnCor comprovaram a capacidade do nosso agente vacinal na indução de anticorpos dirigidos contra o mesmo peptídeo. Não obstante, os soros dos animais pertencentes aos grupos controles, que receberam somente o veículo, não foram reativos contra o StreptInCor. Esta resposta foi consistente e estatisticamente significante nas quatro linhagens estudadas, (figs. 12A, DR2; 12B, DR4; 12C, DQ6; 12D, DQ8). Interessantemente, os soros dos camundongos das linhagens DQ6 e DQ8 apresentaram títulos mais elevados e homogêneos (figs. 12C e D); quando comparados aos das linhagens DR2 e DR4 (figs. 12A e B). 

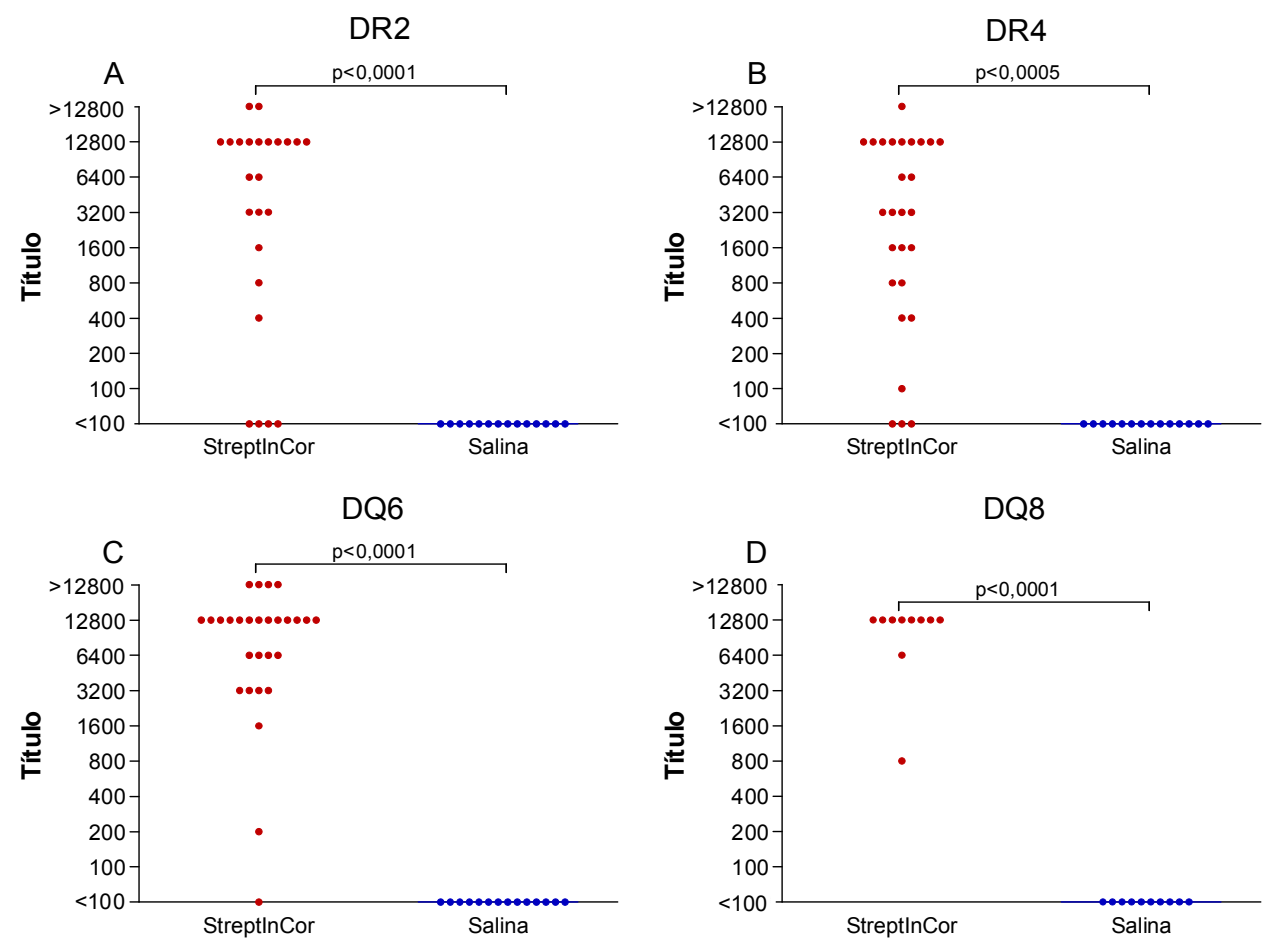

Figura 12. Ensaio imunoenzimático para detecção de imunoglobulinas reativas contra o StreptInCor em grupos de camundongos imunizados (duas doses) com $50 \mu \mathrm{g}$ do mesmo peptídeo (em vermelho) ou somente o veículo (salina, em azul), na presença de $300 \mu \mathrm{g}$ de hidróxido de alumínio. Os pontos representam os valores dos títulos obtidos para cada soro ensaiado. Aos valores negativos já na diluição de 1:100, foi atribuído o valor $<100$. Em A, camundongos da linhagem DR2 (StreptInCor $n=24$, salina $n=14$ ); B, DR4 (StreptInCor $n=27$, salina $n=14$ ); C, DQ6 (StreptInCor $n=28$, salina $n=14$ ) e D, DQ8 (StreptInCor $n=10$, salina $n=10$ ).

\section{Avaliação da durabilidade da resposta imune humoral}

Grupos de camundongos que apresentaram resposta ao StreptInCor nos ensaios de ELISA tiveram amostras de sangue coletadas no primeiro, quarto, oitavo e décimo segundo mês após a última imunização (Figura 13). Todas as linhagens apresentaram animais com resposta imune humoral satisfatória, até oito meses. Entretanto, após doze meses de acompanhamento 5/20 animais da linhagem DR2, 12/25 da linhagem DR4, 12/27 da linhagem DQ6 e 1/10 da linhagem DQ8 obtiveram títulos de anticorpos abaixo do ponto de corte do ensaio de ELISA. 

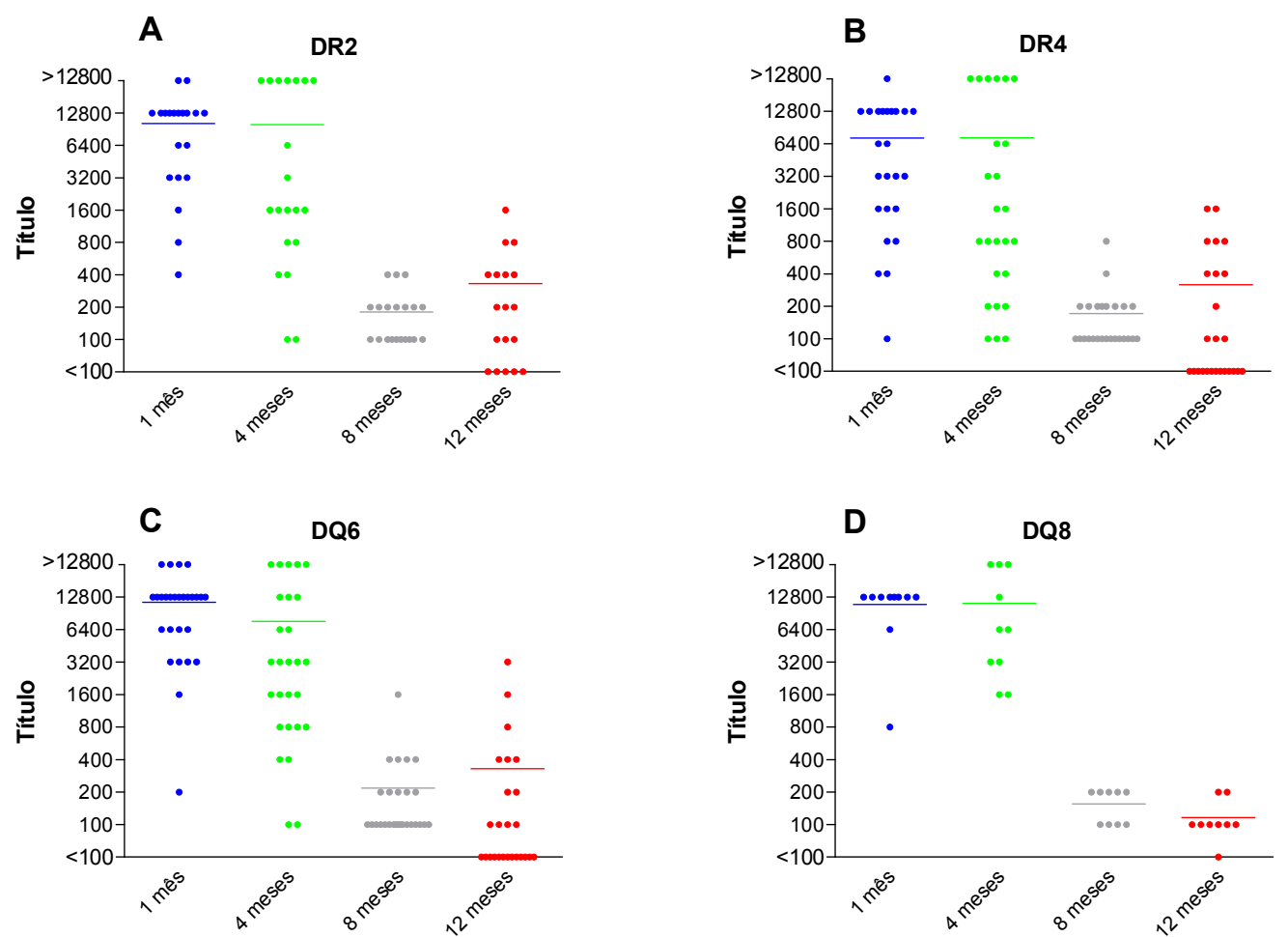

Figura 13. Ensaio imunoenzimático para detecção de imunoglobulinas reativas contra o StreptInCor em grupos de camundongos imunizados (duas doses) com $50 \mu \mathrm{g}$ do mesmo peptídeo, na presença de $300 \mu \mathrm{g}$ de hidróxido de alumínio. Os pontos representam os valores dos títulos obtidos para cada soro ensaiado. $\mathrm{O}$ eixo $\mathrm{X}$ apresenta a periodicidade da coleta de sangue, 1 mês (em azul), 4 meses (em verde), 8 meses (em cinza) e 12 meses (em vermelho), após a última imunização. Aos valores negativos já na diluição de 1:100, foi atribuído o valor <100. Em A, camundongos da linhagem DR2 (StreptInCor $\mathrm{n}=20$ ); B, DR4 (StreptInCor $n=25$ ); C, DQ6 (StreptInCor $n=27$ ) e D, DQ8 (StreptInCor $n=10)$.

\section{Avaliação da produção de subclasses de imunoglobulinas gerada após vacinação com o StreptlnCor}

Foram selecionados 7 camundongos de cada linhagem, os quais apresentaram altos títulos de lgG total contra o StreptInCor, como mostrado na figura 12. Como podemos ver na Figura 14, todas as linhagens apresentaram altos títulos de lgG1 específica ao StreptlnCor, sendo que alguns animais também apresentaram anticorpos das subclasses lgG2b e lgG3. Por outro lado, a produção da subclasse lgG2a não foi observada. 

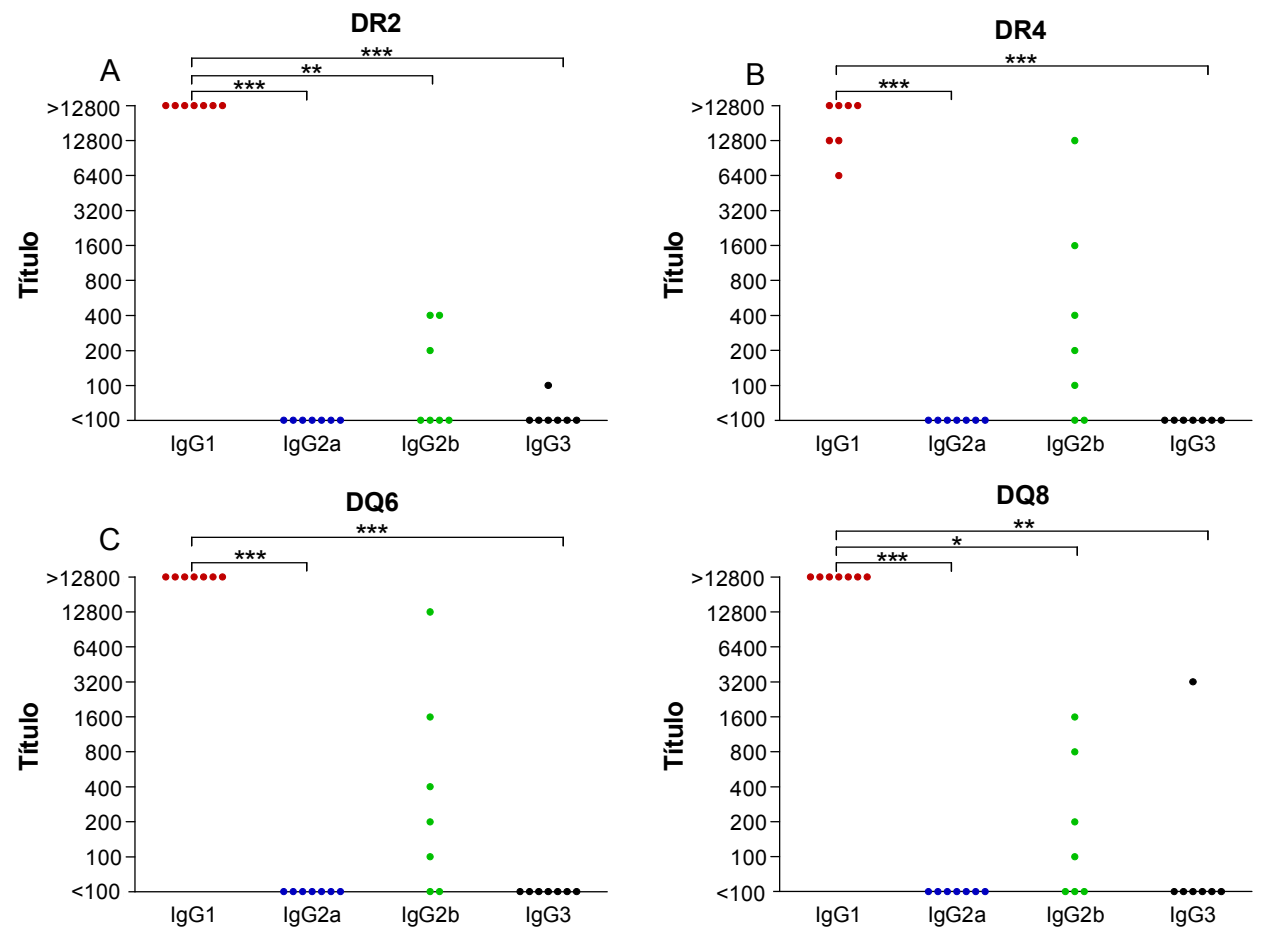

Figura 14. Ensaio imunoenzimático para detecção das subclasses de imunoglobulinas IgG1 (em vermelho), IgG2a (em azul), IgG2b (em verde) e lgG3 (em preto), reativas contra o StreptInCor em grupos de camundongos imunizados com $50 \mu \mathrm{g}$ do mesmo peptídeo, na presença de $300 \mu \mathrm{g}$ de hidróxido de alumínio, em duas doses. Os pontos representam os valores dos títulos obtidos para cada soro ensaiado. Aos valores negativos já na diluição de 1:100, foi atribuído o valor 0 . Em A, camundongos da linhagem DR2 ( $n=07)$; B, DR4 ( $n=07) ; \mathbf{C}$, DQ6 $(n=07)$ e $\mathbf{D}$, DQ8 (n=07). * $p<0,05 ;{ }^{* *}, p<0,01 ;{ }^{* * *}, p<0,001$.

\section{Avaliação da resposta humoral à proteína M1 e miosina cardíaca}

A resposta humoral dos camundongos imunizados foi avaliada quanto à capacidade de reconhecimento de epítopos oriundos da região relativa à seqüência do StreptInCor, presentes na proteína M completa (M1), bem como reatividade cruzada (miosina cardíaca) ou inespecífica (gelatina). A Figura 15 mostra que todos os animais das linhagens DQ6 e DQ8 responderam à proteína M1 (figs. $15 \mathrm{C}$ e D) com títulos inferiores quando comparados com a resposta ao StreptInCor. Dois entre 7 animais das linhagens DR2 e DR4 (figs. 
15 A e B) não foram capazes de reagir contra a proteína a M1. Vale ressaltar que somente a linhagem DQ6 apresentou um resutado estatisticamente significante quando comparado à gelatina e à miosina cardíaca $(p<0,01)$.

Não observamos nenhuma resposta inespecífica ou cruzada, contra a miosina cardíaca, em nenhuma das 4 linhagens de camundongos transgênicos (Fig. 15, p<0,001). Finalmente, todos os soros dos animais DR2, DR4, DQ6 e DQ8 imunizados somente com salina e hidróxido de alumínio não apresentaram resposta contra quaisquer antígenos estudados (dados não mostrados).
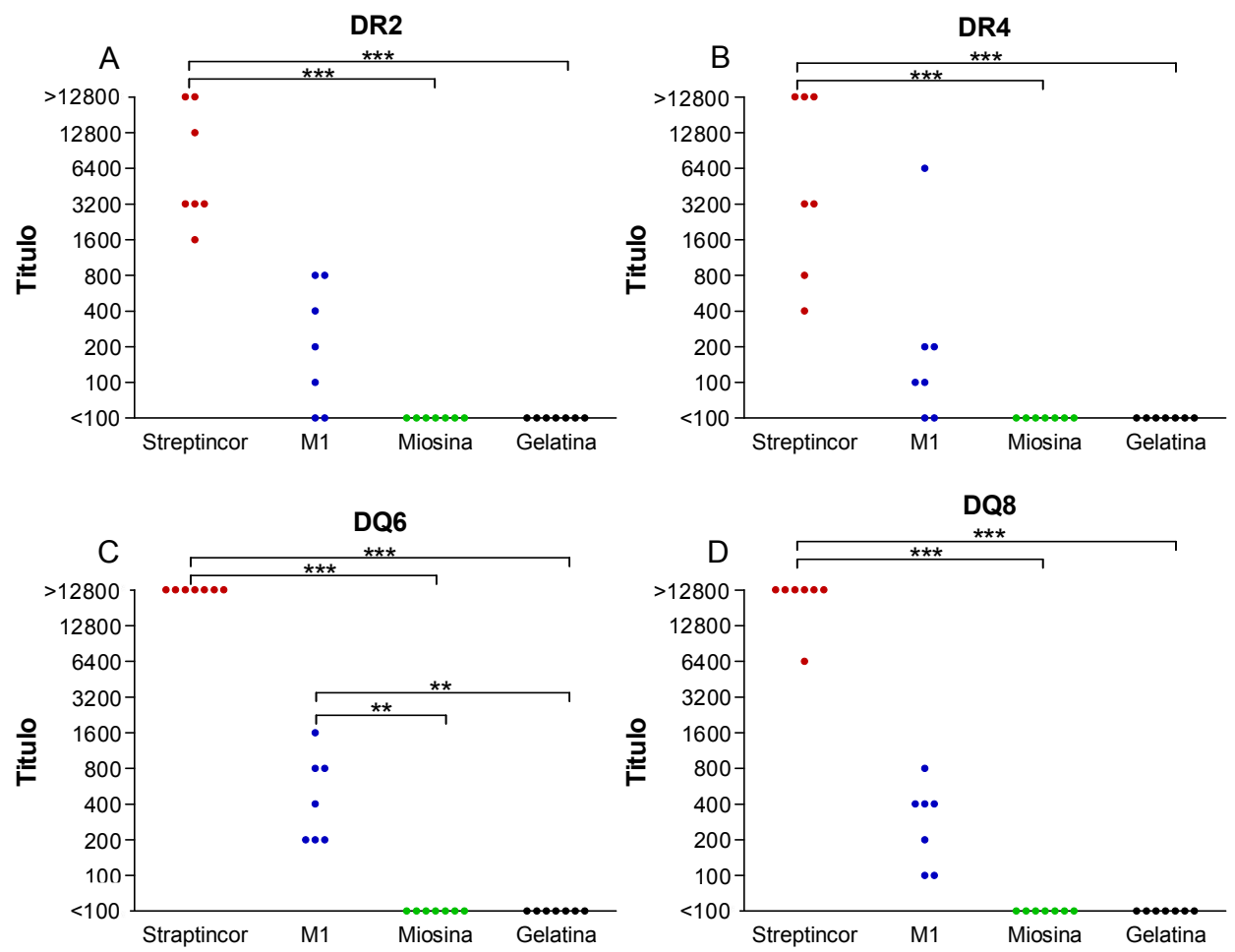

Figura 15. Ensaio imunoenzimático para detecção de imunoglobulinas reativas contra o StreptInCor (em vermelho), proteína M1 recombinante (em azul), miosina (em verde) e gelatina (em preto) em grupos de camundongos imunizados (duas doses) com $50 \mu \mathrm{g}$ de StreptInCor, na presença de $300 \mu \mathrm{g}$ de hidróxido de alumínio. Os pontos representam os valores dos títulos obtidos para cada soro ensaiado. Aos valores negativos já na diluição de 1:100, foi atribuído o valor $<100$. Em A, camundongos da linhagem DR2 ( $n=07)$; B, DR4 $(n=07) ; \mathbf{C}, \mathrm{DQ6}(n=07)$ e D, DQ8 $(n=07) .{ }^{*}, p<0,05 ;{ }^{* *}, p<0,01 ;{ }^{* * *}, p<0,001$. 


\section{Variabilidade Experimental}

Ao longo de todo o trabalho foi identificada uma grande variabilidade da resposta humoral nos diversos experimentos, seja entre animais de um mesmo grupo em um determinado experimento, como também entre experimentos realizados em períodos diferentes. A Figura 16 mostra as repostas humorais obtidas em seis imunizações que foram realizadas no decorrer deste trabalho e a variabilidade da resposta. Vale ressaltar que a produção de animais da linhagem DR2 foi muito baixa, impossibilitando a utilização dos mesmos em mais do que 2 experimentos distintos. Em todos os experimentos verificamos animais que não responderam ao nosso agente vacinal.

Todas as imunizações aqui mostradas foram realizadas nas mesmas condições, diferindo uma das outras apenas em relação à data. 

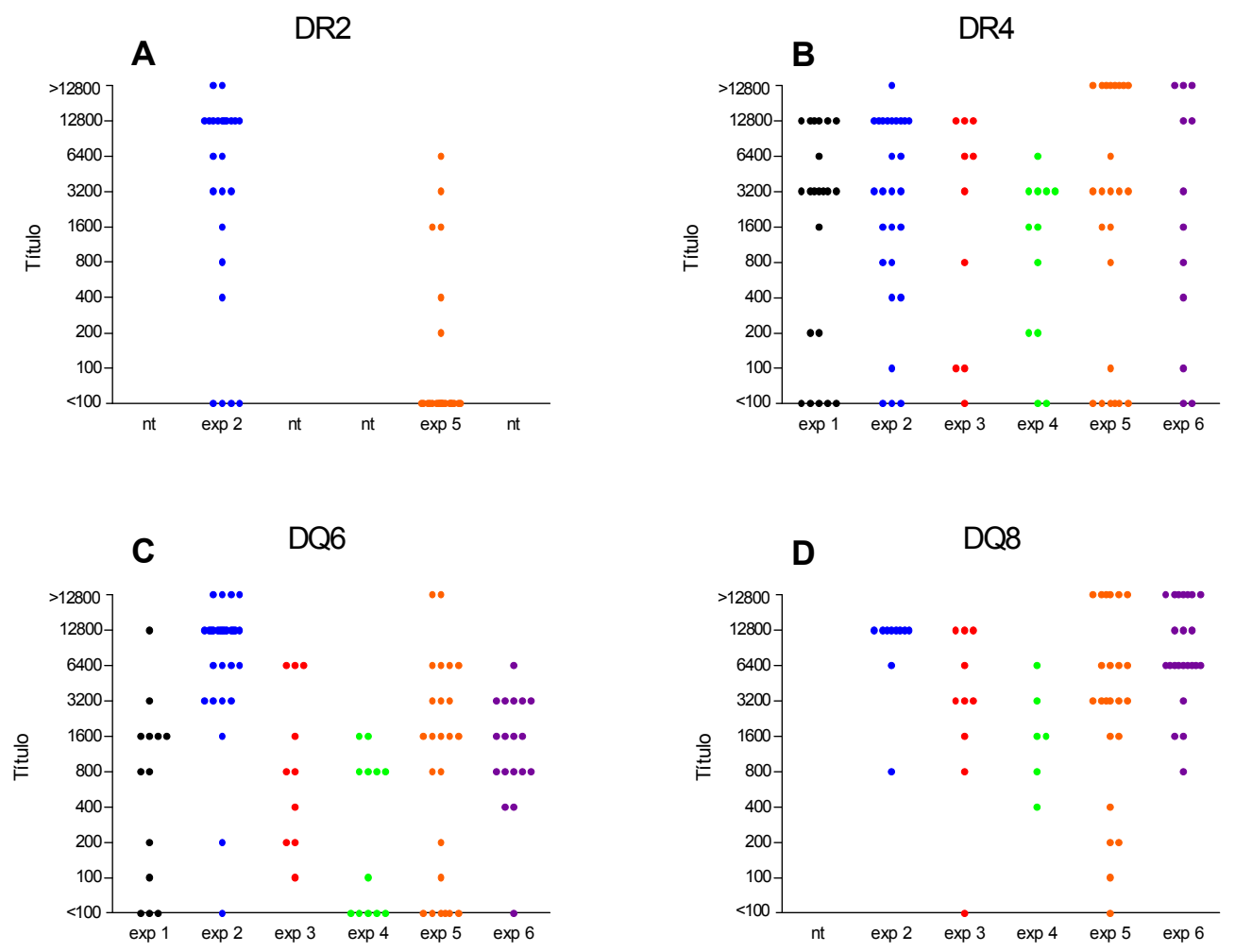

Figura 16. Ensaio imunoenzimático para detecção de anticorpos reativos ao StreptlnCor em grupos de camundongos imunizados com $50 \mu \mathrm{g}$ do mesmo peptídeo, na presença de $300 \mu \mathrm{g}$ de hidróxido de alumínio, em duas doses. O gráfico mostra os experimentos realizados em cada linhagem e os pontos representam os valores dos títulos obtidos para cada soro ensaiado. Aos valores negativos já na diluição de 1:100, foi atribuído o valor <100. Em A, camundongos da linhagem DR2 (2 experimentos); B, DR4 (6 experimentos); C, DQ6 (6 experimentos) e D, DQ8 (5 experimentos). nt - não testado.

\section{Expressão da Molécula HLA X Resposta Humoral}

A variabilidade da resposta humoral obtida nos ensaios de ELISA não é correlacionada à porcentagem de expressão de moléculas HLA de classe II encontradas na superfície das APC's, conforme pode ser visto na Figura 17. As linhagens DR4, DQ6 e DQ8 apresentaram uma linha de tendência paralela ao eixo $X$ cujo deslocamento à direita demonstra um aumento do título de anticorpos obtidos no ELISA. Apenas a linhagem DR2 apresentou uma discreta tendência de aumento do título de anticorpos concomitantemente com um 
aumento da porcentagem de expressão de moléculas HLA-II na superfície de células CD45/B220 positivas, porém houve o inverso em relação à expressão da mesma molécula na superfície de células CD11c positivas.

\section{CD11c}
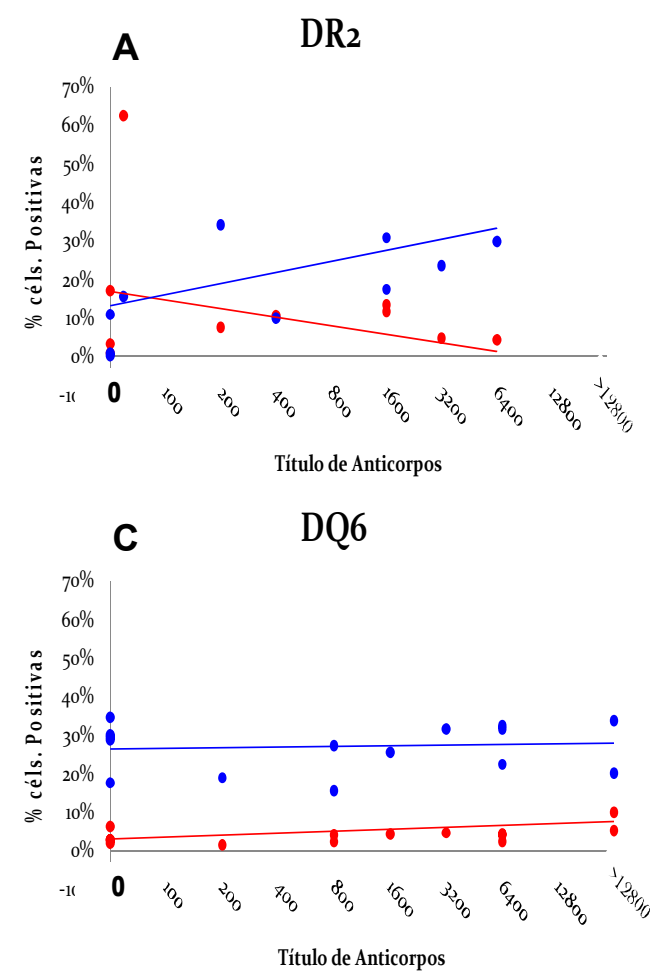

$\mathrm{CD} 45 / \mathrm{B} 220$
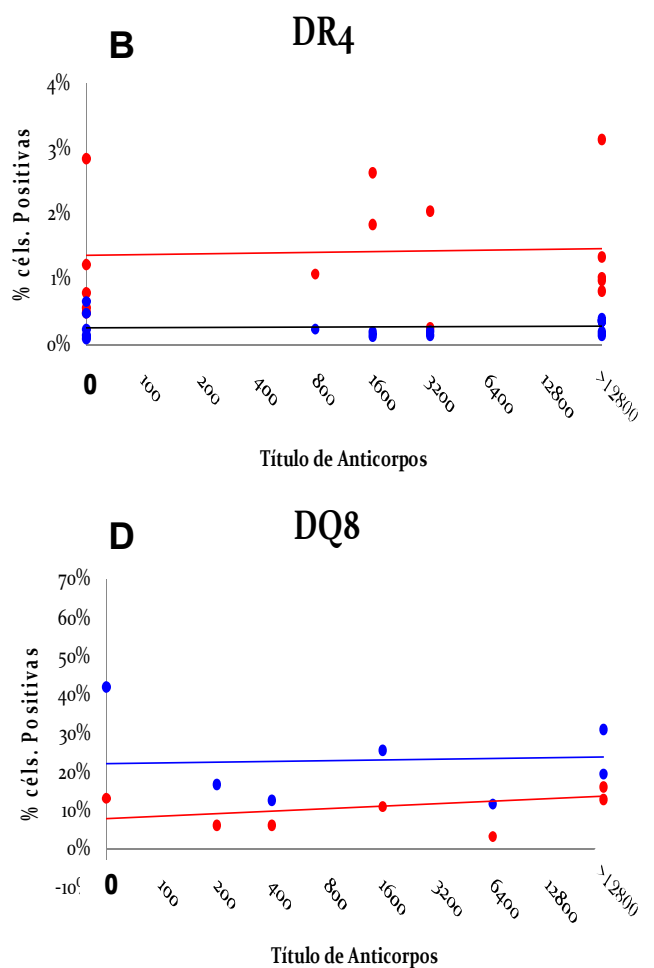

Figura 17. Correlação entre o título de anticorpos obtidos nos ensaios de ELISA (eixo X) com a porcentagem da expressão de moléculas HLA de classe II DR ou DQ (eixo Y), na superfície de células CD11c+ (em vermelho) ou CD45/B220 ${ }^{+}$(em azul). Cada ponto representa um animal, sendo que todo animal irá apresentar um ponto referente à sua porcentagem de células $\mathrm{CD}_{11 \mathrm{c}^{+}}$(em vermelho) e um ponto referente à sua porcentagem de células $\mathrm{CD} 45 / \mathrm{B}^{2} 20^{+}$(em azul), e ambas estarão paralelas ao eixo $\mathrm{x}$, representando o título de anticorpos que este animal apresentou no ensaio de ELISA. Em A, camundongos da linhagem DR2 ( $n=10) ; B, D R 4(n=15) ; C, D Q 6(n=15)$ e D, DQ8 $(n=07)$. 


\section{Imunização com Adjuvante de Freund}

Para avaliar o padrão da resposta humoral na presença de um adjuvante capaz de polarizar a resposta imunológica para o tipo celular utilizamos o adjuvante de Freund e os resultados obtidos foram semelhantes àqueles observados com o hidróxido de alumínio, ou seja, variação de resposta ao peptídeo após as imunizações nas linhagens DR2, DR4 e DQ6, como pode ser observado na Figura 18. O lote de animais da linhagem DR2, imunizado com o StreptInCor, não apresentou resposta significativa contra o agente vacinal.
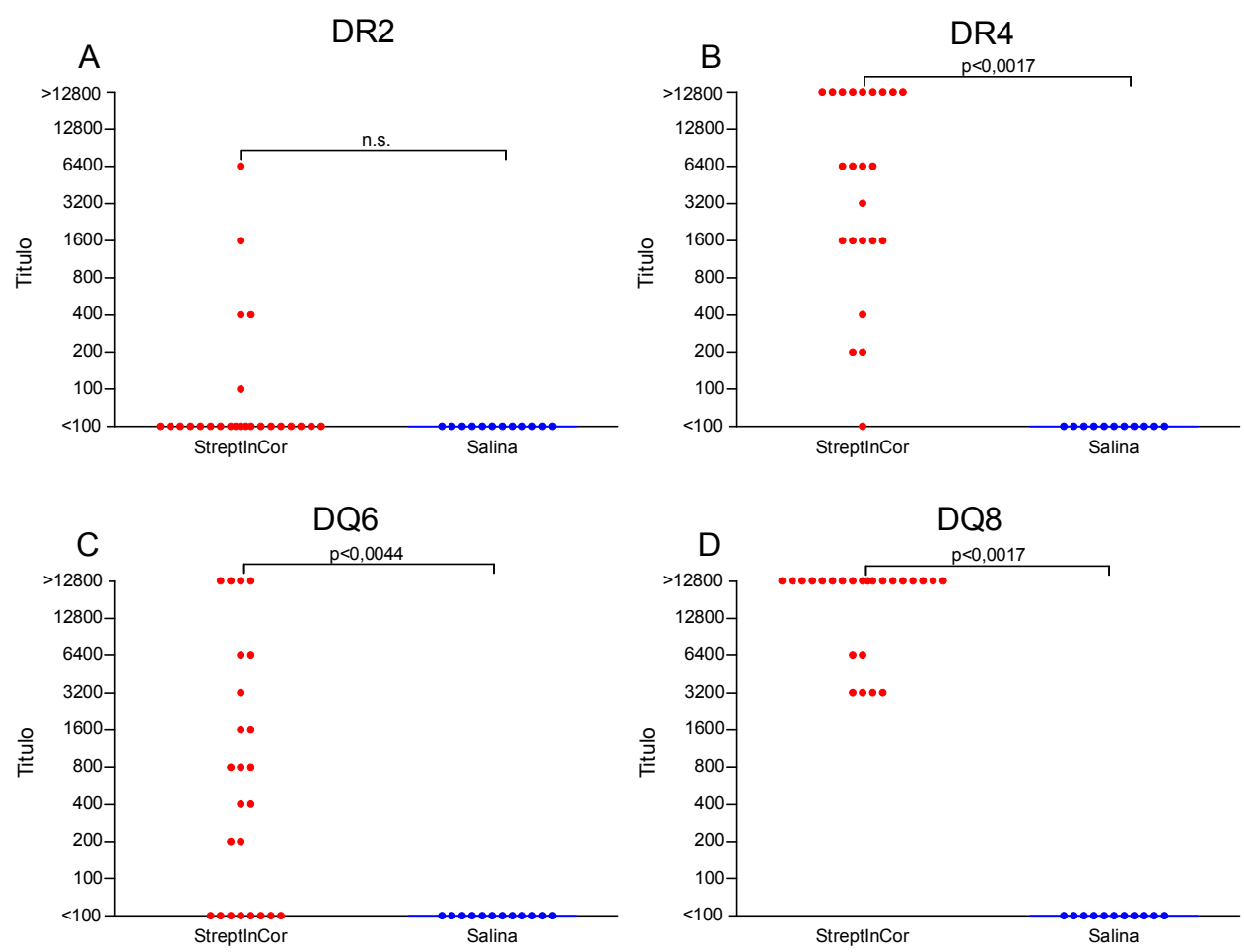

Figura 18. Ensaio imunoenzimático para detecção de imunoglobulinas reativas contra o StreptInCor em grupos de camundongos imunizados (duas doses) com $50 \mu \mathrm{g}$ do mesmo peptídeo (em vermelho) ou somente o veículo (salina, em azul), na presença de adjuvante completo de Freund $v / v\left(1^{\text {a }}\right.$ dose) e adjuvante incompleto de Freund $v / v$ ( $2^{a}$ dose). Os pontos representam os valores dos títulos obtidos para cada soro ensaiado. Aos valores negativos já na diluição de 1:100, foi atribuído o valor $<100$. Em A, camundongos da linhagem DR2 (StreptlnCor $n=24$, salina $n=12$ ); $B$, DR4 (StreptInCor $n=23$, salina $n=11$ ); C, DQ6 (StreptInCor $n=24$, salina $n=12$ ) e D, DQ8 (StreptlnCor $n=24$, salina $n=11$ ). 


\section{Comparação entre imunizações com StreptlnCor e Ovalbumina.}

Para verificar se a complexidade estrutural do imunógeno era capaz de induzir uma resposta divergente daquela encontrada quando imunizávamos os camundongos com nosso peptídeo vacinal, um grupo de camundongos, previamente imunizados com o StreptInCor e cuja resposta humoral foi altamente variável, foram imunizados com uma proteína integral. A figura 19 mostra que a variabilidade da resposta manteve-se quando utilizamos um imunógeno não relacionado (ova). Somente os animais da linhagem DQ6 apresentaram uma diferença significativa $(p<0,04)$ com uma resposta à ovalbumina maior em comparação ao StreptInCor.
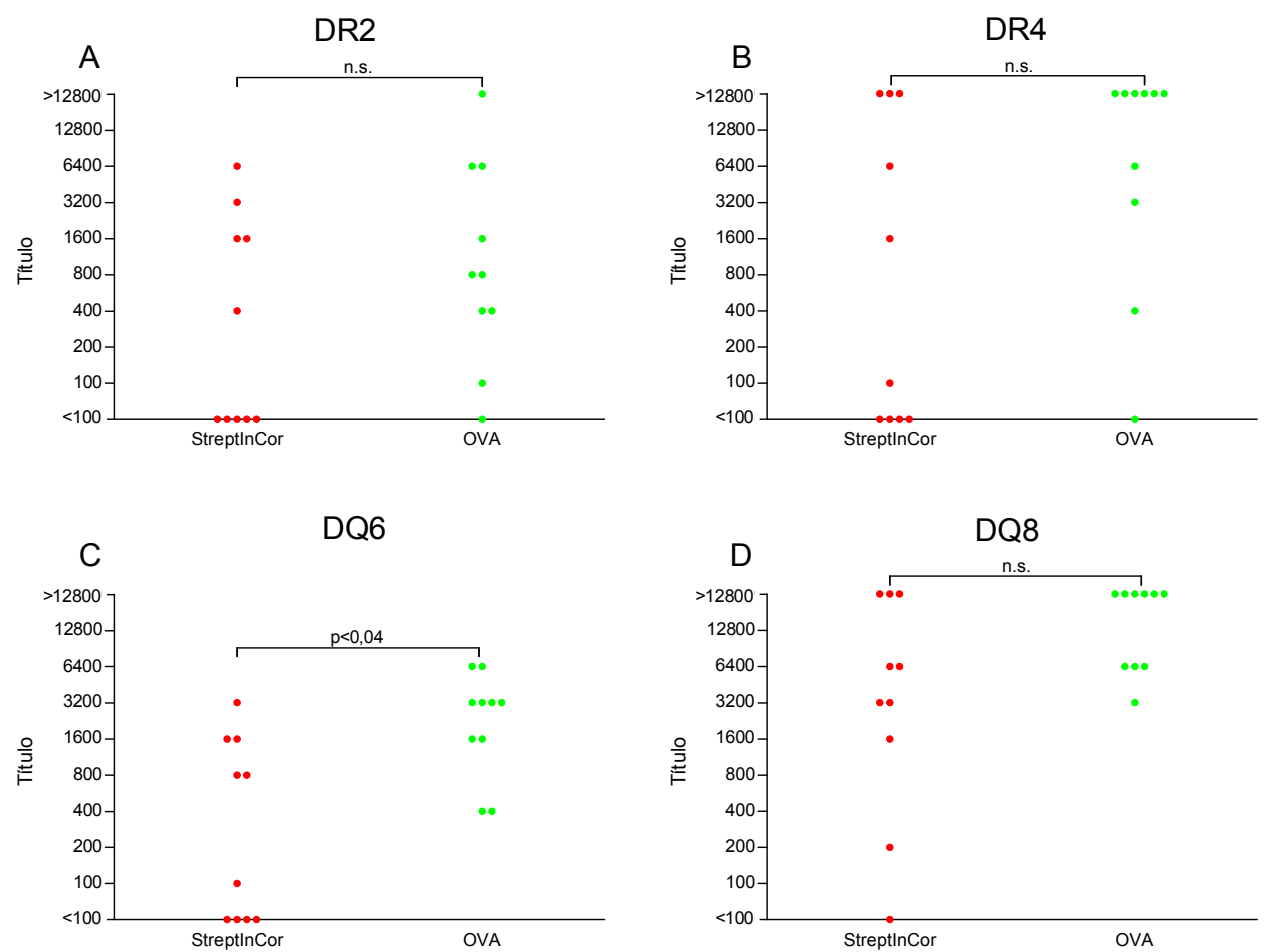

Figura 19. Ensaio imunoenzimático para detecção de imunoglobulinas reativas ao StreptInCor (em vermelho) e Ovalbumina (em verde). Ambos os antígenos foram administrados em duas doses contendo $50 \mu \mathrm{g}$ do antígeno adsorvidos em $300 \mu \mathrm{g}$ de hidróxido de alumínio. Os pontos representam os valores dos títulos obtidos 
para cada soro ensaiado. Aos valores negativos já na diluição de $1: 100$, foi atribuído o valor <100. Em A, camundongos da linhagem DR2 $(n=10) ; \mathbf{B}$, DR4 $(n=10) ; C, D Q 6(n=10)$ e D, DQ8 $(n=10)$.

\section{Ensaio de Proliferação Celular por CFSE}

A análise da proliferação celular feita por citometria de fluxo foi realizada com o corante intracelular CFSE e anticorpos específicos para as moléculas CD3, CD4 e CD8. A figura 20 mostra o "gate" de análise onde é possível mensurar a porcentagem de células $\mathrm{CD}^{+} / \mathrm{CD}^{+} \mathrm{CFSE}^{\text {baixo }}$ e $\mathrm{CD}^{+} / \mathrm{CD}^{+}$ CFSE $^{\text {baixo }}$. Na figura 21 verifica-se o índice de estimulação (I.E.) obtido pela análise dos dados da proliferação celular com CFSE. Devido à ausência de animais da linhagem DR2, estes não foram avaliados nestes experimentos. Entre as diferentes linhagens estudadas, os DQ8 imunizados com o StreptInCor apresentaram proliferação tanto de células $\mathrm{T} \mathrm{CD}^{+}$como $\mathrm{CD} 8^{+}$ $($ I.E. $=3,4$ e 2,1, respectivamente) (Fig. 23). Já os linfócitos dos animais DR4 tiveram uma proliferação limitrofe entre os $\operatorname{T~CD4}^{+}($I.E. $=1,95)$ e positiva entre os $\mathrm{CD}^{+}(\mathrm{I} . \mathrm{E} .=2,4)($ Fig. 21), enquanto as células dos camundongos DQ6 não foram reativas. Vale ressaltar que as reatividades estudadas foram obtidas somente quando uma concentração de $50 \mu \mathrm{g} / \mathrm{mL}$ de StreptInCor foi utilizada para o estímulo das células. 
A

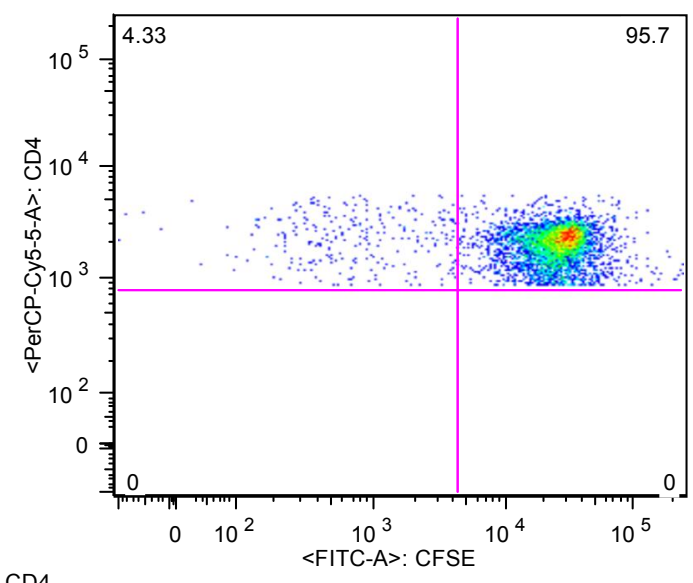

CD4

G1_TB1-50.fCs

Event Count: 6097

B

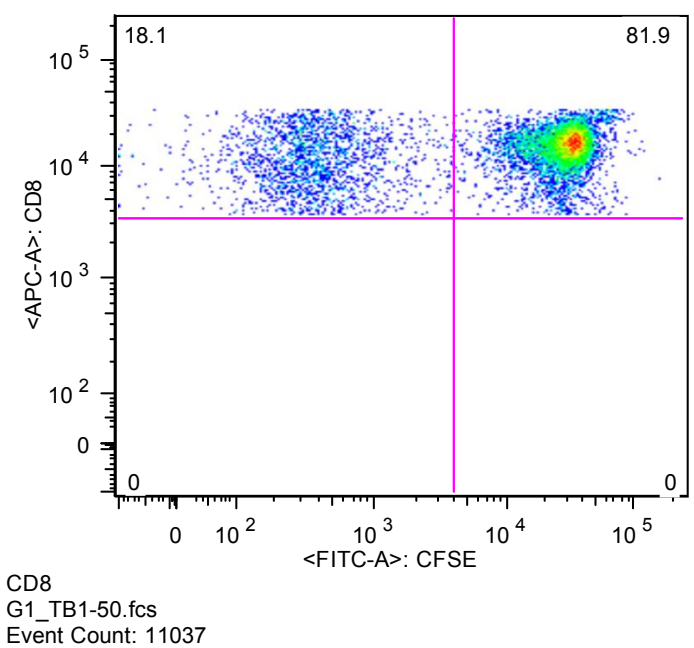

Figura 20. Em A há a demonstração de um "gate" onde é possível ver a porcentagem de células $\mathrm{CD}^{+} / \mathrm{CD}^{+} \mathrm{CFSE}^{\text {baixo }}(4,33 \%)$ e em B células $\mathrm{CD}^{+} / \mathrm{CD}^{+} \mathrm{CFSE}^{\text {baixo }}(18,1 \%)$.

A DR4 - StreptlnCor

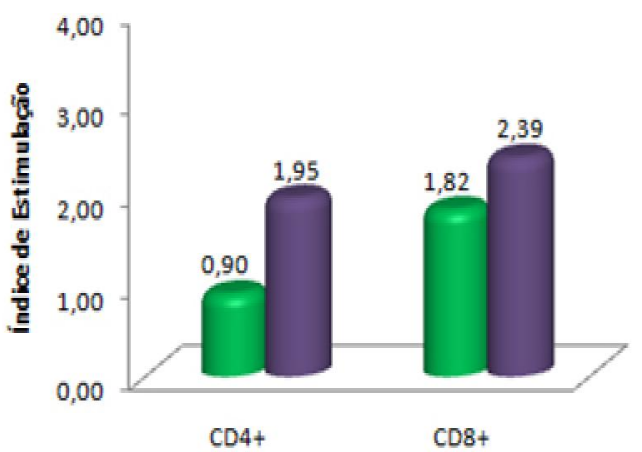

B DR4 - Salina

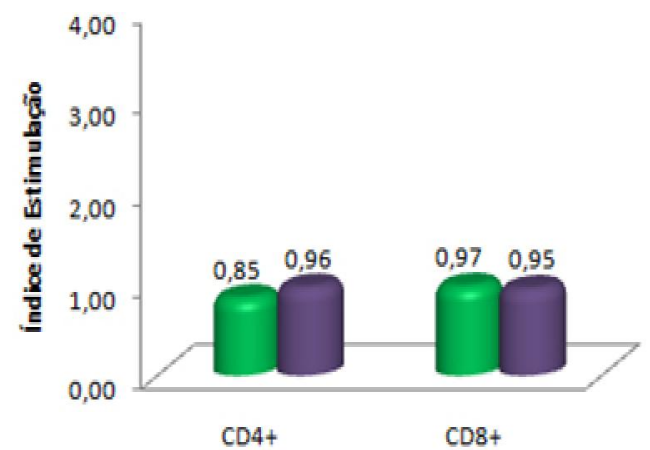

Figura 21. Gráfico mostrando o resultado obtido, em índice de estimulação (I.E.), após a proliferação celular dos animais da linhagem DR4, tendo como estímulo $10 \mu \mathrm{g}$ (em verde) ou $50 \mu \mathrm{g}$ de StreptInCor (em roxo). Em A o grupo imunizado com o StreptInCor, em B o grupo imunizado apenas com salina. 

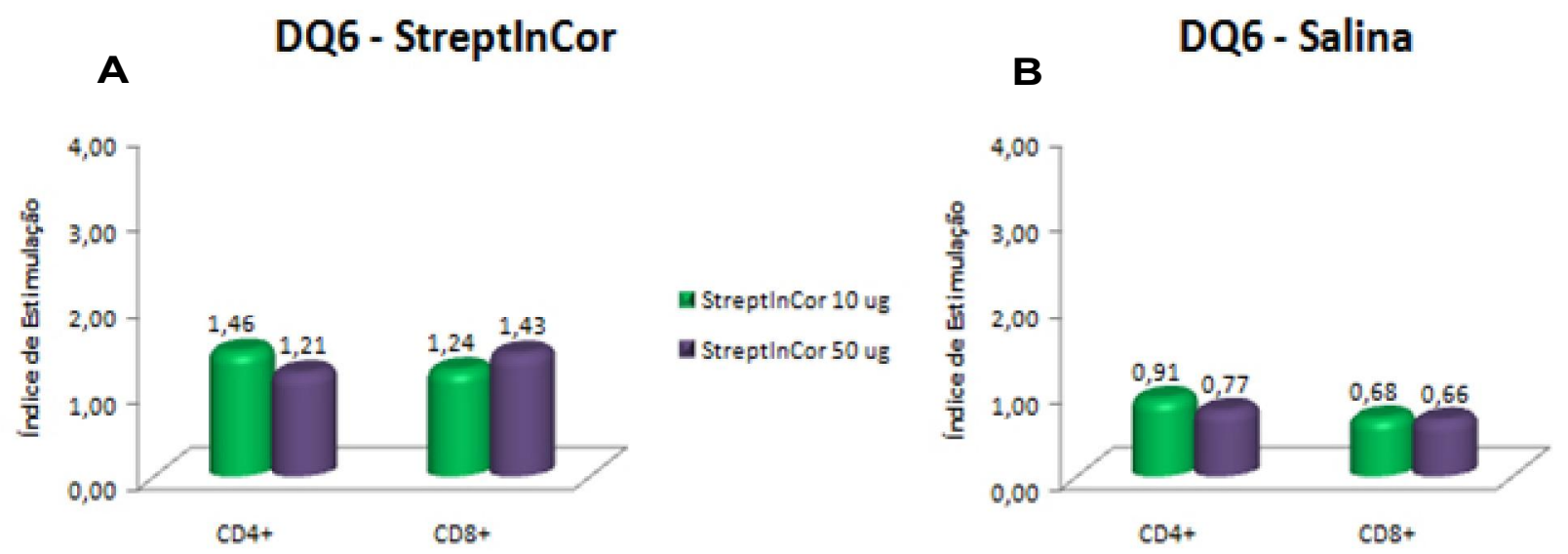

Figura 22. Gráfico mostrando o resultado obtido, em índice de estimulação (I.E.), após a proliferação celular dos animais da linhagem DQ6, tendo como estímulo $10 \mu \mathrm{g}$ (em verde) ou $50 \mu \mathrm{g}$ de StreptlnCor (em roxo). Em A o grupo imunizado com o StreptInCor, em $\mathbf{B}$ o grupo imunizado apenas com salina.

\section{A DQ8 - StreptlnCor}

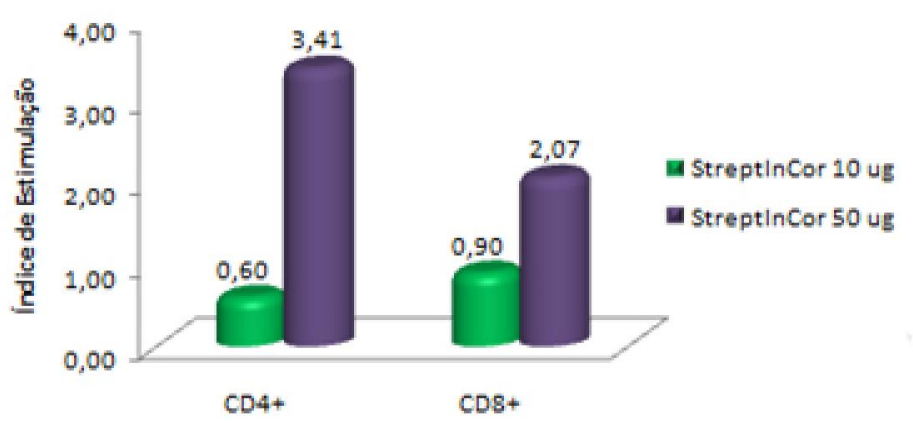

B DQ8 - Salina

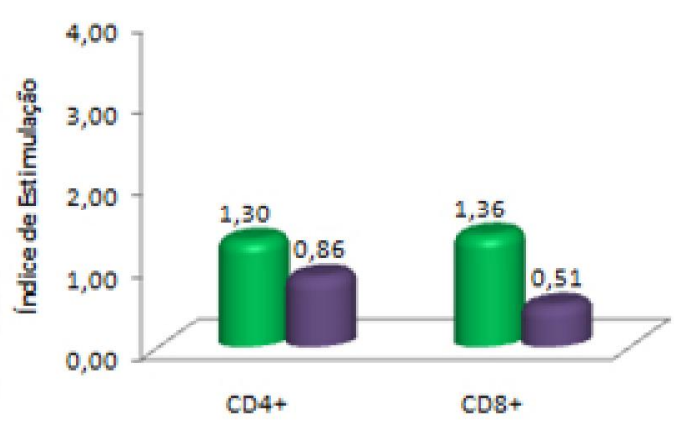

Figura 23. Gráfico mostrando o resultado obtido, em índice de estimulação (I.E.), após a proliferação celular dos animais da linhagem DQ8, tendo como estímulo $10 \mu \mathrm{g}$ (em verde) ou $50 \mu \mathrm{g}$ de StreptInCor (em roxo). Em A o grupo imunizado com o StreptInCor, em B o grupo imunizado apenas com salina.

\section{Padrão celular de memória após proliferação}

As células dos camundongos imunizados e controles foram classificadas, após a proliferação celular, quanto à presença das moléculas CD44 e CD62L. As figuras 24, 25 e 26 mostram os resultados obtidos após a estimulação dos esplenócitos com 10 e $50 \mu \mathrm{g}$ do StreptlnCor. Nos grupos 
imunizados e estimulados com $50 \mu \mathrm{g}$ do agente vacinal foi constatado que as células que proliferaram, tanto $\mathrm{CD}^{+}$quanto $\mathrm{CD}^{+}$, eram em sua maioria de memória efetora (CD44 $\left.{ }^{+} \mathrm{CD}^{2} \mathrm{~L}^{-}\right)$. Apenas a linhagem DQ8 apresentou uma porcentagem de linfócitos $\mathrm{CD}^{+}$de memória central $\left(\mathrm{CD}_{4} 4^{+} \mathrm{CD} 2 \mathrm{~L}^{-}\right)$, após o

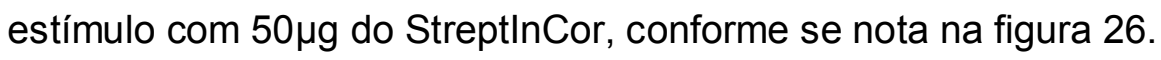

A

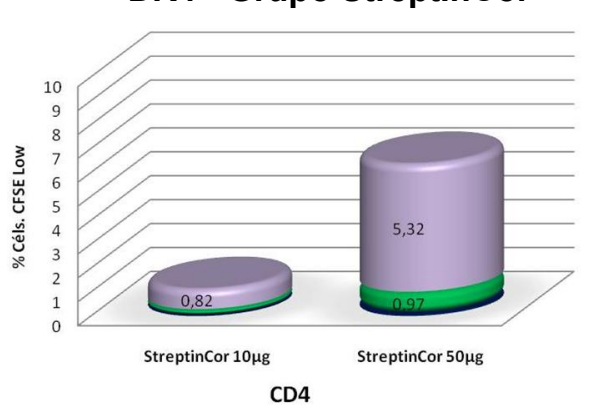

C DR4 - Grupo Salina

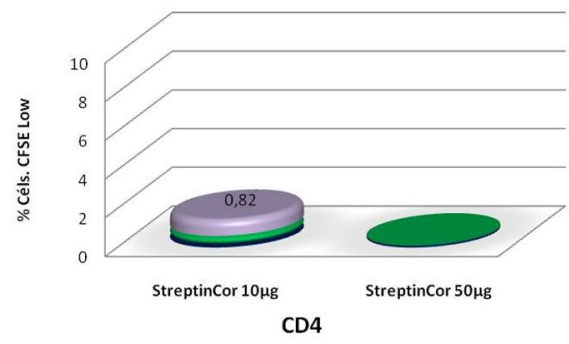

CD44- ${ }^{-}$CD2L ${ }^{+}$NAIVE

\section{B DR4 - Grupo StreptInCor}

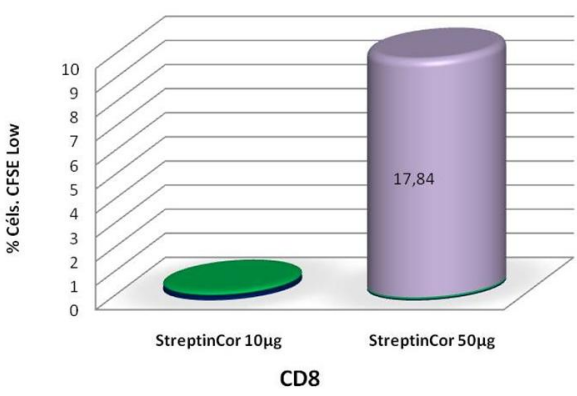

D DR4 - Grupo Salina

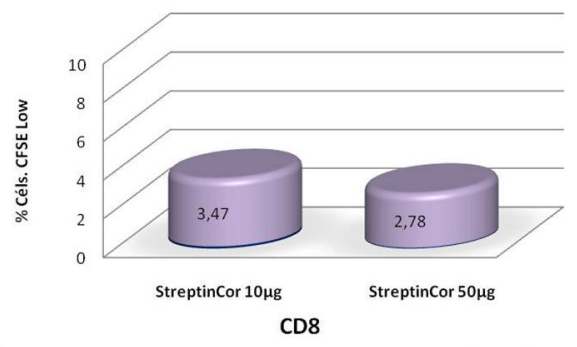

${\mathrm{CD} 44^{+}{ }^{\mathrm{CD}^{2}} \mathrm{~L}^{-}}^{-}$TEM

Figura 24. Análise do padrão de proliferação celular $\left(C F S E^{\text {Baixo }}\right)$ de camundongos da linhagem DR4 com a porcentagem de células Naïve (CD44- e CD62 $\mathrm{L}^{+}$) em azul, linfócitos de memória central (CD44 ${ }^{+}$e CD62 $\left.\mathrm{L}^{+}\right)$em verde e linfócitos de memória efetora (D44 ${ }^{+} \mathrm{e}$ $\mathrm{CD}^{2} \mathrm{~L}^{-}$) em roxo. Nos gráficos $\mathbf{A}$ e $\mathbf{C}$ células $\mathrm{CD} 4^{+}$, em $\mathbf{B}$ e $\mathbf{D}$ células $\mathrm{CD}^{+}$. Na parte superior encontra-se o grupo imunizado com StreptInCor e na parte inferior o grupo imunizado com salina. 
A

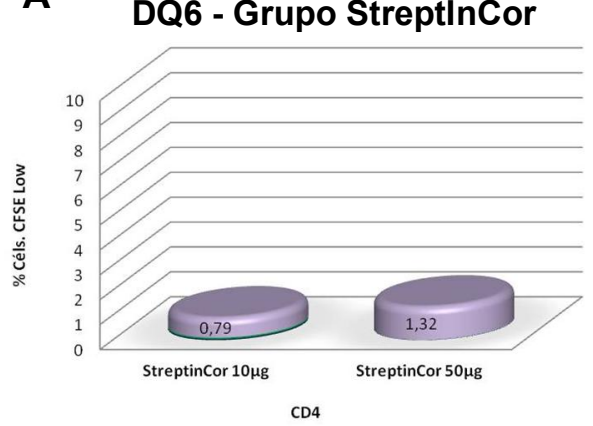

C

\section{DQ6 - Grupo Salina}

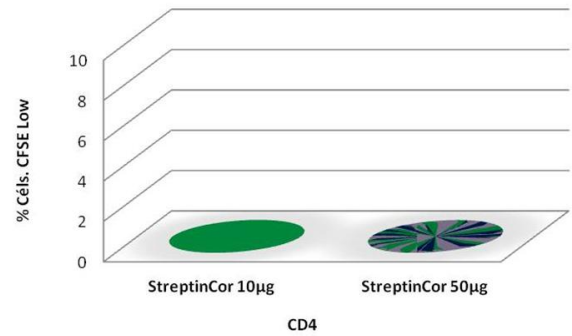

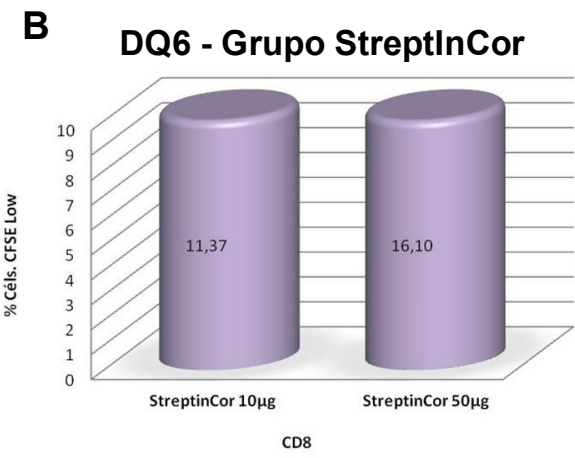

D

\section{DQ6 - Grupo Salina}

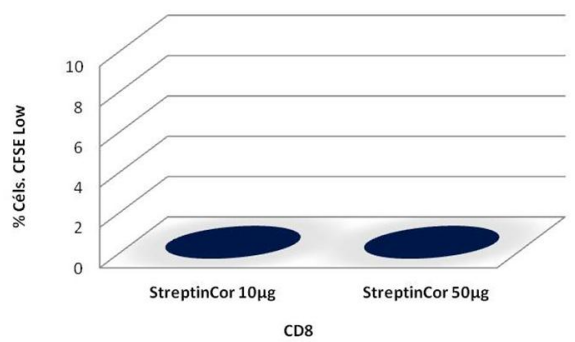

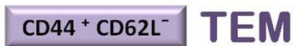

Figura 25. Análise do padrão de proliferação celular de camundongos da linhagem DQ6 com a porcentagem de células Naïve (CFSE ${ }^{\text {Baixo }} \mathrm{CD}_{4} 4^{-}$e $\mathrm{CD} \mathrm{CL}^{+}$) em azul, linfócitos de memória central $\left(\mathrm{CFSE}^{\text {Baixo }} \mathrm{CD} 4^{+}\right.$e $\mathrm{CD} 2 \mathrm{~L}^{+}$) em verde e linfócitos de memória efetora (CFSE ${ }^{\text {Baixo }} \mathrm{CD}_{4} 4^{+}$e $\mathrm{CD} \mathrm{L}^{-}$) em roxo. Nos gráficos $\mathbf{A}$ e $\mathbf{C}$ células $\mathrm{CD} 4^{+}$, em B e D células $\mathrm{CD}^{+}$. Na parte superior encontra-se o grupo imunizado com StreptInCor e na parte inferior o grupo imunizado com salina. 
A

DQ8 - Grupo StreptInCor

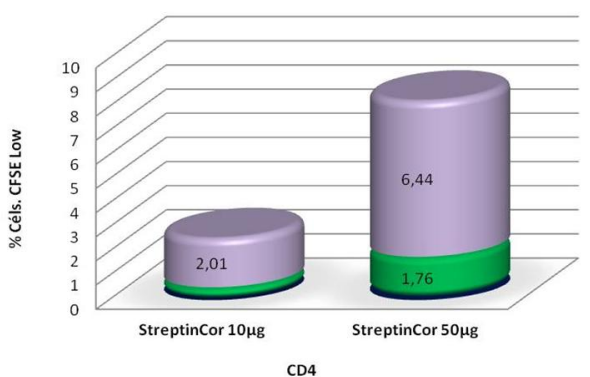

C

DQ8 - Grupo Salina

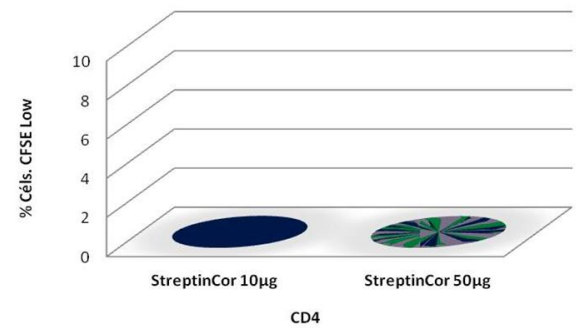

${\text { CD44- } \text { CD62L }^{+}}_{\text {NAIVE }}$
B DQ8 - Grupo StreptInCor

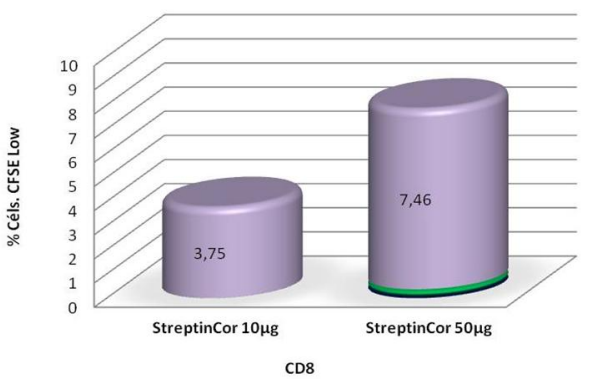

D

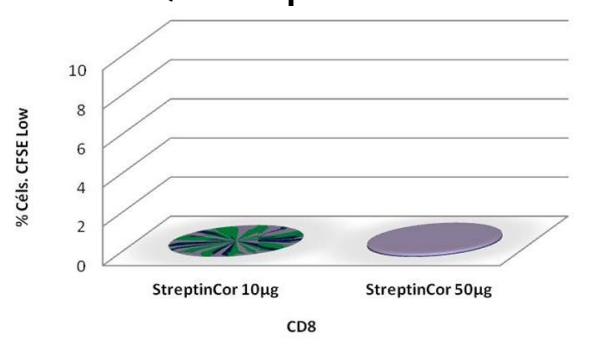

${\mathrm{CD} 44^{+}{ }^{+} \mathrm{CD} 62 \mathrm{~L}^{-}}^{-}$TEM

Figura 26. Análise do padrão de proliferação celular de camundongos da linhagem DR4 com a porcentagem de células Naïve (CFSE ${ }^{\text {Baixo }} \mathrm{CD}_{4} 4^{-}$e $\mathrm{CD} \mathrm{L}^{+}$) em azul, linfócitos de memória central $\left(\mathrm{CFSE}^{\text {Baixo }} \mathrm{CD} 4^{+}\right.$e $\mathrm{CD} 2 \mathrm{~L}^{+}$) em verde e linfócitos de memória efetora (CFSE ${ }^{\text {Baixo }} \mathrm{CD}_{4} 4^{+}$e $\mathrm{CD} 62 \mathrm{~L}^{-}$) em roxo. Nos gráficos $\mathbf{A}$ e $\mathbf{C}$ células $\mathrm{CD} 4^{+}$, em B e D células $\mathrm{CD}^{+}$. Na parte superior encontra-se o grupo imunizado com StreptInCor e na parte inferior o grupo imunizado com salina.

\section{Análise Histopatológica}

Foram analisados, pelo serviço de Patologia do InCor, os órgãos de 65 animais utilizados em nossos experimentos de durabilidade da resposta imune humoral, 41 animais imunizados com o StreptInCor e 24 com salina, compreendendo todas as linhagens estudadas (Tabelas 1 e 2), foram sacrificados após 12 meses de acompanhamento e tiveram seu coração, articulações, rins, cérebro, fígado e baço retirados e encaminhado para análise histológica. Não observamos nenhum indício de lesão tecidual ocasionada por 
ação do nosso agente vacinal e/ou reação de ordem auto-imune, conforme pode ser observado nas Figuras 27 e 28.

Tabela 1: Análise do tecido cardíaco dos animais imunizados com o streptlnCor e salina.

\begin{tabular}{c|c|c|c|c|ccccc}
\hline \multirow{2}{*}{ Linhagem } & \multicolumn{2}{|c|}{$\begin{array}{c}\text { Animais } \\
\text { imunizados com } \\
\text { StreptInCor }\end{array}$} & \multicolumn{2}{|c|}{ Salina } & \multirow{2}{*}{ Peric } & Mioc & vMi & vAo & vTric \\
\cline { 2 - 5 } & Machos & Fêmeas & Machos & Fêmeas & & & & & \\
DR2 & 4 & 6 & 0 & 6 & $\mathrm{~N}$ & $\mathrm{~N}$ & $\mathrm{~N}$ & $\mathrm{~N}$ & $\mathrm{~N}$ \\
DR4 & 3 & 8 & 5 & 5 & $\mathrm{~N}$ & $\mathrm{~N}$ & $\mathrm{~N}$ & $\mathrm{~N}$ & $\mathrm{~N}$ \\
DQ6 & 7 & 4 & 0 & 6 & $\mathrm{~N}$ & $\mathrm{~N}$ & $\mathrm{~N}$ & $\mathrm{~N}$ & $\mathrm{~N}$ \\
DQ8 & 9 & 0 & 4 & 0 & $\mathrm{~N}$ & $\mathrm{~N}$ & $\mathrm{~N}$ & $\mathrm{~N}$ & $\mathrm{~N}$ \\
\hline
\end{tabular}

Peric - Pericárdio; Mioc - Miocárdio; vMi - valva mitral; vAo - valva aórtica; vTric - valva tricúspide; $\mathbf{N}$ = Normal. 


\section{TABELA 2}

\begin{tabular}{|c|c|c|c|c|c|c|c|c|c|}
\hline \multirow[b]{2}{*}{ Linhagem } & \multirow[b]{2}{*}{ Imunização } & \multicolumn{7}{|c|}{ Órgãos Analisados } & \multirow[b]{2}{*}{ MO (\%) cel. } \\
\hline & & Gênero & Animais (N) & SNC & Rim & Baço & Fígado & Articulação & \\
\hline \multirow{4}{*}{ DR2 } & \multirow{3}{*}{ StreptInCor } & Machos & 4 & $\mathrm{~N}$ & $1 / 4 \operatorname{Inf} \mathrm{LMN}$ & $\mathrm{N}$ & $1 / 4 \mathrm{Hmt}-2$ & $\mathrm{~N}$ & $98-100$ \\
\hline & & & & & & & 1/6 Esteat - 1 & & \\
\hline & & Fêmeas & 6 & $\mathrm{~N}$ & $2 / 6 \mathrm{Hmt}-1$ & $\mathrm{~N}$ & $\begin{array}{c}\text { 1/6 Esteat - } 3 \\
1 / 6 \mathrm{Hmt}-2\end{array}$ & $\mathrm{~N}$ & $98-100$ \\
\hline & Salina & Fêmeas & 6 & $\mathrm{~N}$ & 1/6 Hmt - 1 & $\mathrm{~N}$ & $\begin{array}{l}\text { 1/6 Esteat - } 1 \\
\text { 1/6 Esteat - } 2 \\
\text { 1/6 Esteat - } 3\end{array}$ & $\mathrm{~N}$ & $90-100$ \\
\hline \multirow{6}{*}{ DR4 } & \multirow{3}{*}{ StreptInCor } & Machos & 3 & $\mathrm{~N}$ & $\mathrm{~N}$ & $1 / 3 \mathrm{Hmt}-2$ & $\mathrm{~N}$ & $\mathrm{~N}$ & $90-100$ \\
\hline & & & & & & & & & \\
\hline & & Fêmeas & 8 & $\mathrm{~N}$ & $1 / 8$ Inf LMN & $2 / 8 \mathrm{Hmt}-1$ & $2 / 8 \mathrm{Hmt}-1$ & $\mathrm{~N}$ & $90-100$ \\
\hline & \multirow{3}{*}{ Salina } & Machos & 5 & $\mathrm{~N}$ & $\mathrm{~N}$ & $1 / 5 \mathrm{Hmt}-2$ & $2 / 5 \mathrm{Hmt}-2$ & $\mathrm{~N}$ & $90-100$ \\
\hline & & & & & & & & & \\
\hline & & Fêmeas & 5 & $\mathrm{~N}$ & $1 / 5$ Inf LMN & $4 / 5 \mathrm{Hmt}-1$ & 2/5 Hmt - 1 & $\mathrm{~N}$ & $90-100$ \\
\hline \multirow{4}{*}{ DQ6 } & \multirow{3}{*}{ StreptInCor } & Machos & 7 & $\mathrm{~N}$ & $\mathrm{~N}$ & $1 / 7 \mathrm{Hmt}-1$ & $1 / 7 \mathrm{Hmt}-2$ & $\mathrm{~N}$ & $98-100$ \\
\hline & & & & & & & & & \\
\hline & & Fêmeas & 4 & $\mathrm{~N}$ & $\mathrm{~N}$ & $\mathrm{~N}$ & 2/4 Hmt - 1 & $\mathrm{~N}$ & $98-100$ \\
\hline & Salina & Fêmeas & 4 & $\mathrm{~N}$ & $\mathrm{~N}$ & $2 / 4 \mathrm{Hmt}-1$ & $1 / 4 \mathrm{Hmt}-2$ & $\mathrm{~N}$ & $98-100$ \\
\hline \multirow[b]{2}{*}{ DQ8 } & StreptInCor & Machos & 9 & $\mathrm{~N}$ & $\mathrm{~N}$ & 2/9 Hmt - 1 & $\begin{array}{l}5 / 9 \mathrm{Hmt}-1 \\
2 / 9 \mathrm{Hmt}-3\end{array}$ & $\mathrm{~N}$ & 100 \\
\hline & Salina & Machos & 4 & $\mathrm{~N}$ & $\mathrm{~N}$ & $\begin{array}{l}1 / 4 \mathrm{Hmt}-1 \\
1 / 4 \mathrm{Hmt}-2 \\
1 / 4 \mathrm{Hmt}-3\end{array}$ & $\begin{array}{l}1 / 4 \mathrm{Hmt}-1 \\
1 / 4 \mathrm{Hmt}-2 \\
1 / 4 \mathrm{Hmt}-3\end{array}$ & $\mathrm{~N}$ & 100 \\
\hline
\end{tabular}

SNC - Sistema nervoso central; Inf LMN - Infiltrado leucocitário mononuclear; MO - Medula óssea (classificada quanto a sua \% de celularidade); $\mathbf{N}$ - Normal

HMT - Hematopoiese extramedular e Esteat - Esteatose; classificadas em: 1- leve, 2 - moderada e 3 intensa. 

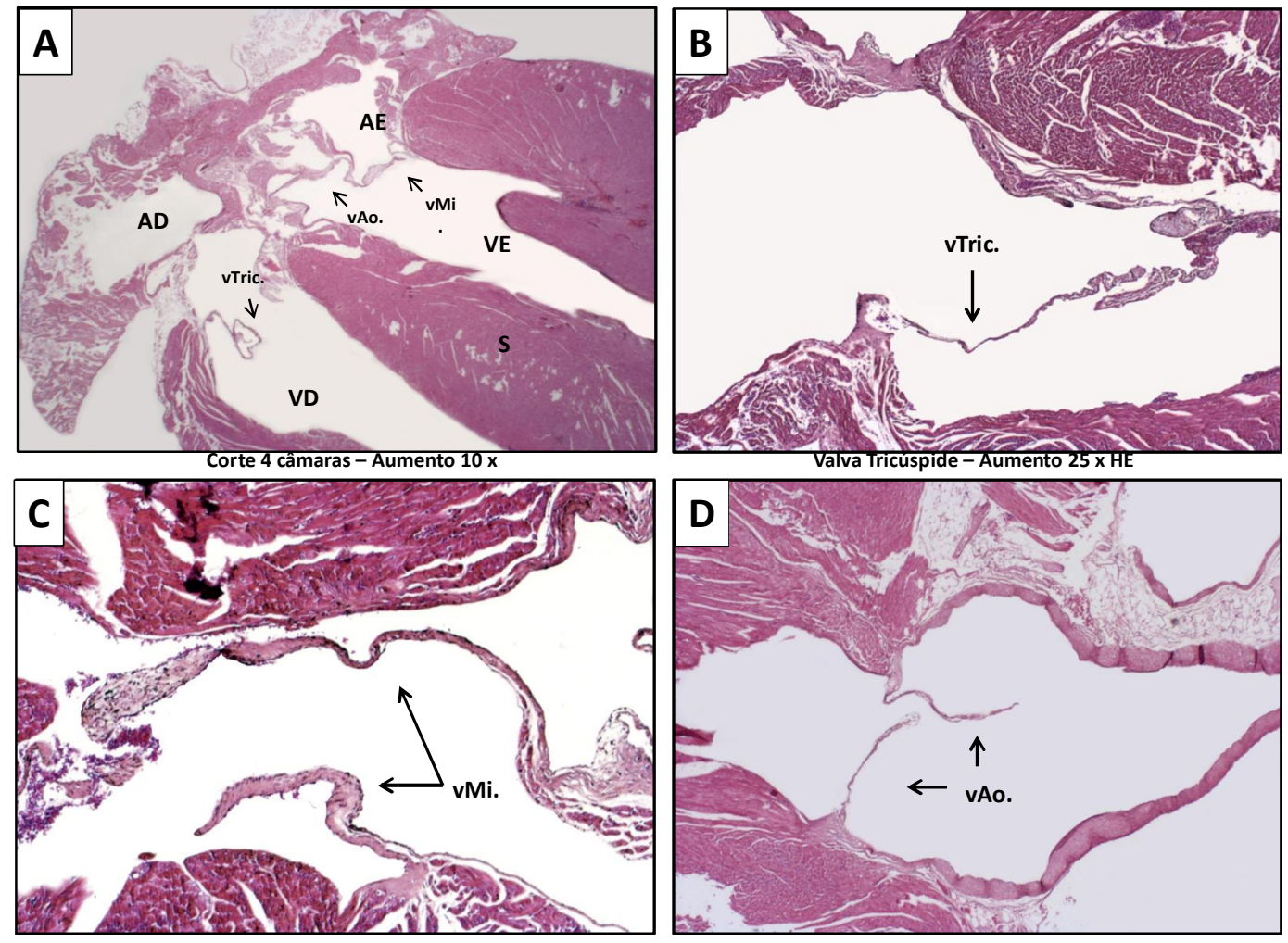

Valva Mitral - Aumento 50 x HE

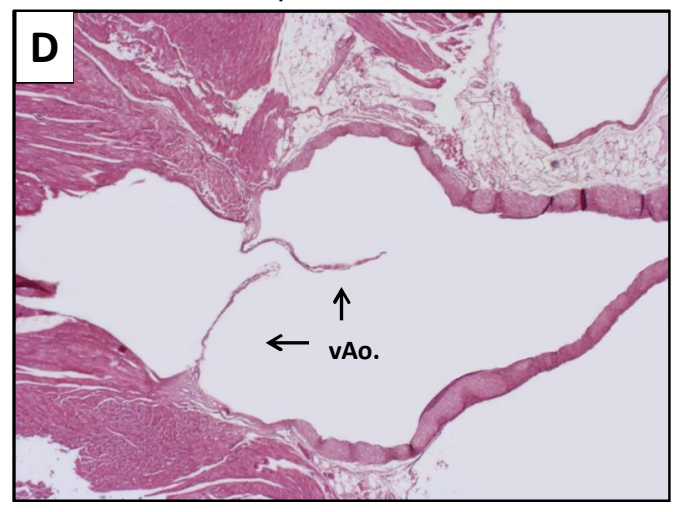

Valva Aórtica - Aumento 25 x HE

Figura 27. Amostra de corte histológico do tecido cardíaco para avaliação das valvas, miocárdio e pericárdio. VD - ventrículo Direito; VE - ventrículo esquerdo; AD - átrio direito; AE - átrio esquerdo; S - septo interventricular; vMi - valva mitral; vAo - valva aórtica; vTric - valva tricúspide. Em A corte histológico apresentando as 4 câmaras cardíacas (aumento 10x); $\mathbf{B}$ valva tricúspide (aumento 25x); C valva mitral (aumento 50x) e D valva aórtica (aumento $25 x)$. Os cortes histológicos foram corados hematoxilina e eosina (HE). 

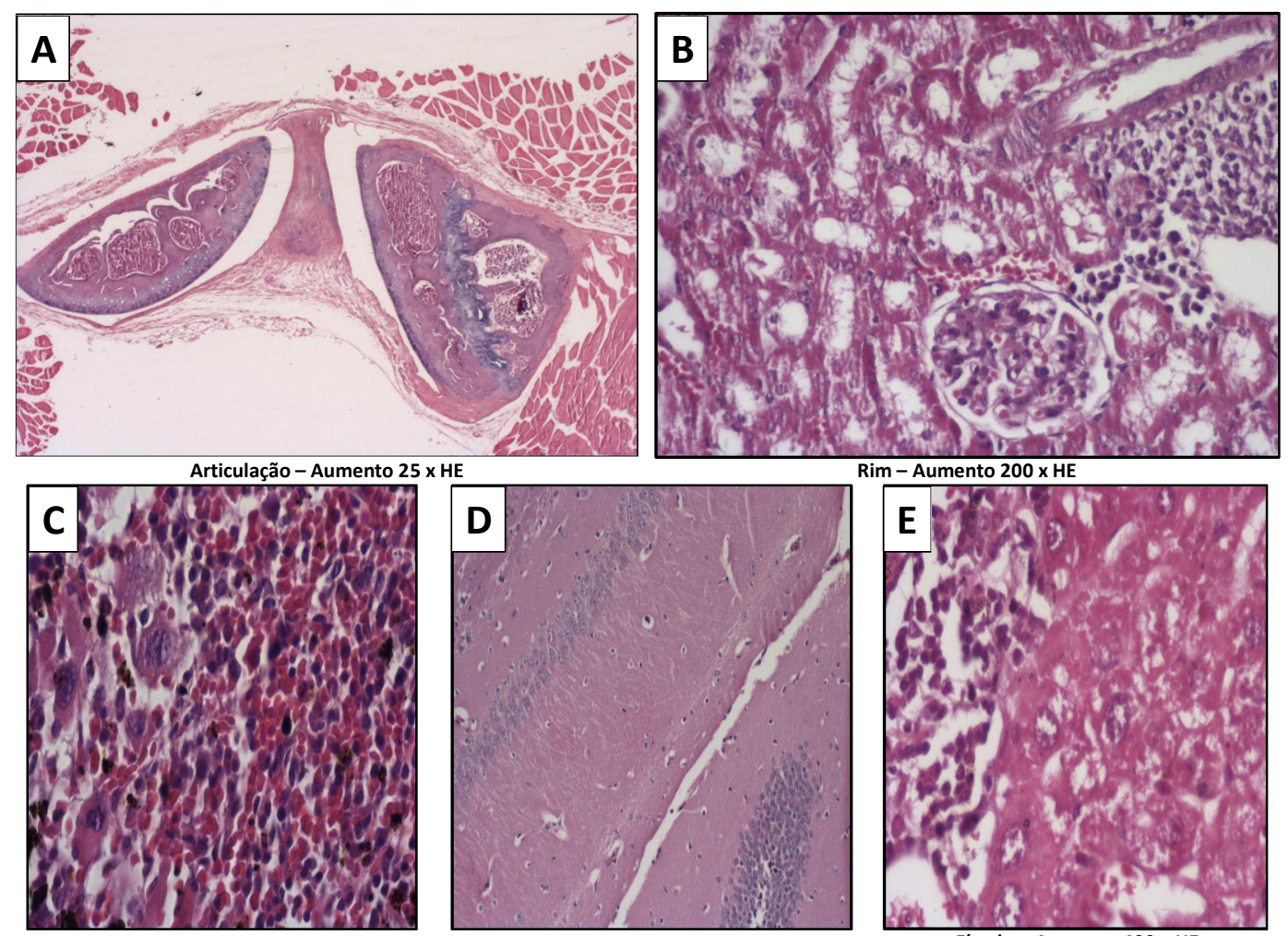

Baço - Aumento 400 x HE
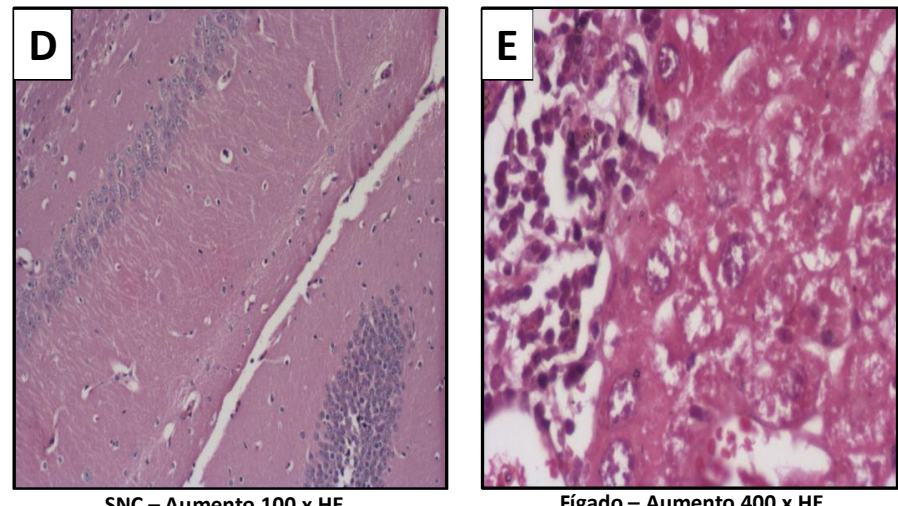

Figura 28. Amostras dos cortes histológicos analisados. Em A articulação (aumento 25x); B rim (aumento 200x); C baço (aumento 400x); D cérebro (aumento 100x) e E fígado (aumento 400x). Os cortes histológicos foram corados hematoxilina e eosina (HE). 
Os animais utilizados para o desenvolvimento deste trabalho apresentam moléculas do complexo principal de histocompatibilidade de classe Il transgênicas. Essas moléculas são cruciais no desencadeamento da resposta imune, tanto pela apresentação de antígenos processados aos receptores de linfócitos $\mathrm{T}$ (TCR), como pela ativação dos linfócitos B que serão estimulados a produzir anticorpos específicos. Estes animais não expressam as moléculas de classe II murinas (IA/IE) e têm a apresentação de antígenos exógenos realizada apenas pelas moléculas HLA de classe II (DR ou DQ), produto do transgene que lhes foi inserido (Cheng et al, 2003).

Essas características tornam esses animais excelentes modelos experimentais para o estudo de um agente vacinal, uma vez que prediz a capacidade deste agente, após ser processado por células apresentadoras, ativar os linfócitos T e desencadear uma resposta imunológica adaptativa com comprometimento de linfócitos $B$, produção de linfócitos de memória, e acima de tudo, uma resposta imune similar ou próxima àquela encontrada e humanos.

Os dados aqui apresentados mostram que os camundongos transgênicos para as moléculas de HLA de classe II humanas DR2, DR4, DQ6 e DQ8 desenvolvem boa resposta humoral, com produção de anticorpos específicos para o agente vacinal (StreptInCor). Estes anticorpos, principalmente da subclasse lgG1, foram capazes de reconhecer não só o próprio peptídeo utilizado na imunização como distinguir os epítopos no contexto da proteína M1 que é heteróloga àquela utilizada para o desenvolvimento do StreptInCor. Além disso, não observamos indícios de 
efeitos deletérios aos animais conforme os dados obtidos na análise histopatológica dos órgãos estudados.

Apesar dos camundongos da linhagem DR2 apresentarem dificuldades para a reprodução e não responderam ao procedimento para super ovulação, foi possível contornar este problema utilizando os machos e fêmeas transgênicos para o gene DR2 em procedimentos de retro cruzamento entre fêmeas e machos portadores do gene DQ6. Assim, obtivemos machos e fêmeas que expressavam o gene DR2 e, interessantemente, não expressaram o gene DQ6. Após algumas gerações de camundongos, em função do retro cruzamento confirmamos que os animais obtidos expressavam somente o gene DR2, em detrimento do DQ6 parental, sugerindo homozigose para DR2. Outra dificuldade que tivemos, sobretudo no início do estabelecimento das colônias, foi o baixo número de animais gerados que expressavam o transgene, fato observado para todas as linhagens. Contornamos estes problemas aumentando os números de matrizes, com a formação de novos casais. Apesar dos animais transgênicos se reproduzirem mais lentamente que às linhagens convencionais, os camundongos das linhagens DR4 e DQ6 foram os que se adaptaram melhor em nosso ambiente e produziram camundongos com maior freqüência.

Estes camundongos já foram utilizados em trabalhos similares para a avaliação de uma vacina multi-epitópica contra o vírus da imunodeficiência humana. Neste trabalho as quatro linhagens de camundongos transgênicos (DR2, DR4, DQ6 e DQ8) apresentaram boa resposta proliferativa de linfócitos T $\mathrm{CD}^{+}$, enquanto que a resposta proliferativa dos linfócitos $\mathrm{T} \mathrm{CD}{ }^{+}$foi superior 
nos camundongos que apresentavam as moléculas HLA-DR2 e DR4. Ao analisar a produção de IFN- $\gamma$ pela técnica de ELISPOT, as quatro linhagens produziram boa quantidade dessa citocina, sendo que mais uma vez os animais das linhagens portadoras das moléculas HLA-DR2 e DR4 apresentaram uma resposta maior. Por fim, ao estudar a capacidade proliferativa individual, ao estimulo de cada um dos 18 peptídeos presentes nessa vacina multi-epitópica, foi observado que a linhagem de camundongos DQ6 apresentou a melhor capacidade proliferativa individual (10/18) em relação às linhagens DR2 (3/18), DR4 (4/18) e DQ8 (1/18) (Ribeiro et al, 2010).

Em nossos experimentos para a avaliação da resposta imune humoral nos camundongos transgênicos utilizamos o hidróxido de alumínio como adjuvante. A utilização de substâncias para induzir o aumento da resposta imune foi demonstrada pelos estudos pioneiros de Ramon (1955), que mostrou ser possível aumentar artificialmente os níveis de antitoxinas tetânicas produzidas por uma vacina ao adicionar à fórmula substâncias como amido, lectina ou saponinas. Estas substâncias, quando combinadas aos antígenos, apresentam a propriedade de induzir níveis mais altos de imunidade e, portanto, receberam o nome de adjuvantes ou, em certos casos, imunoestimulantes. Os adjuvantes incrementam o afluxo de linfócitos e modulam a permanência de outras células inflamatórias no local de deposição do antígeno, aumentando o tempo de exposição em função da liberação mais lenta, prolongando sua interação com os macrófagos e células apresentadoras de antígenos. A grande questão na utilização de adjuvantes em vacinas está na toxicidade e nos efeitos adversos de muitas formulações (Gupta \& Siber, 
1995). Edelman (1980) listou inúmeros critérios que garantem a segurança de vacinas conjugadas a adjuvantes.

Dentre os diversos adjuvantes descritos, os sais de alumínio têm sido utilizados em vacinas veterinárias e humanas desde 1930. Seu uso apresenta pequena ou nenhuma toxicidade sistêmica. O hidróxido de alumínio induz resposta imunológica do tipo Th2 (T helper 2), associada com a produção de interleucina 4 (IL-4) e anticorpos $\lg G 1$, $\lg E$ e $\lg A$ secretória (Mosmann \& Coffman, 1989), estimulando principalmente a imunidade humoral, sendo muito pobre a indução de resposta mediada por célula (Schirmbeck et al, 1994).

A escolha do hidróxido de alumínio como adjuvante em nossos ensaios experimentais teve base nos dados já descritos na literatura sobre sua funcionalidade e utilização em larga escala nas diversas vacinas em uso, sendo possível dessa forma, diminuir a dose necessária de antígeno, reduzindo os custos das vacinas (Singh \& O'Hagan, 1999). A capacidade imunogênica do StreptInCor "in vivo", em camundongos isogênicos (BALB/c e C57BL/6) e "outbred" (Swiss), foi estudada com duas imunizações contendo $10 \mu \mathrm{g}$ do StreptInCor. No entanto os camundongos transgênicos, portadores de HLA de classe II humanos não apresentaram boa resposta para essa concentração. Após realização de uma cinética de dose-resposta ao StreptInCor, constatamos que duas doses de $50 \mu \mathrm{g}$ foram necessárias para a obtenção de uma resposta humoral semelhante à observada para os camundongos convencionais. Observamos uma vigorosa produção de anticorpos específicos por animais imunizados com o StreptInCor em todas as linhagens transgênicas. Vale ressaltar que os camundongos que expressavam os transgenes DQ6 e DQ8, 
cuja média de título dos anticorpos era de aproximadamente 1:12800, apresentaram uma resposta imune humoral mais elevada que os animais que expressavam os genes DR2 e DR4 com médias dos títulos de 1:5000 e 1:4000, respectivamente. Estes dados sugerem apresentação antigênica mais eficaz por parte de moléculas DQ6 e DQ8 em relação às moléculas de classe II do tipo DR. Também observamos ausência de resposta imune humoral em alguns animais das diversas linhagens provavelmente por deficiências do repertório de células $\mathrm{T}$.

Dentre as subclasses de $\lg G$, verificamos principalmente a produção de IgG1, observação esperada, uma vez que a indução deste isotipo é dependente de IL-4, produzida em resposta imune do tipo Th2, observada em imunizações na qual se emprega o hidróxido de alumínio (Cox \& Coulter, 1997; Hunter, 2002; Stewart-Tull, 2003). O predomínio de resposta do tipo Th2 foi corroborado pela ausência da produção de imunoglobulinas específicas ao StreptInCor, da subclasse IgG2a, cuja produção é induzida pelo IFN- $\gamma$, uma citocina fundamental em respostas do tipo Th1. Interessantemente, observamos a produção de lgG2b (dependente da produção de TGF- $\beta$ ), específica ao StreptInCor em alguns animais das quatro linhagens estudas. Finalmente, produção significativa de $\lg G 3$, que é regulada pela produção de IFN- $\gamma$, foi observada em um animal da linhagem DQ8, imunizado com o StreptInCor.

Tendo comprovado que os anticorpos gerados após a imunização eram específicos ao StreptInCor, procuramos avaliar a capacidade de reconhecimento de sua seqüência em uma proteína heteróloga. $O$ fato da 
região C-terminal ser conservada na maioria das cepas de S. pyogenes, o que possibilita a produção de uma vacina universal, bem como o fato da proteína M1 ser o sorotipo mais prevalente em casos de estreptococcias no mundo e em São Paulo, nos levou a estudar a capacidade de reconhecimento cruzado pelos anticorpos dos animais imunizados com o StreptlnCor e a proteína M1 recombinante. Observamos que a maioria dos soros hiperimunes foi capaz de reconhecer os epítopos presentes nessa proteína $M$ heteróloga, este fato é indicativo de que os anticorpos produzidos são capazes de interagir com diferentes cepas de S. pyogenes. Apesar dos resultados promissores, há necessidade de se avaliar a reatividade dos anticorpos contra diferentes cepas do S. pyogenes, e desta forma comprovar a abrangência obtida com as imunizações.

Diversas cepas de $S$. pyogenes já foram relacionadas ao desenvolvimento da FR/DRC e glomerulonefrite, sendo consideradas reumatogênicas ou nefritogênicas, respectivamente. Recentemente em um estudo realizado por nosso grupo (Freschi de Barros et al, 2006; manuscrito em preparação) foram genotipadas 177 amostras de S. pyogenes isoladas de diversos sítios de infecção obtidas do banco de cepas do Laboratório Central do Hospital das Clínicas (HC-FMUSP), no período de 2001 a 2008. Neste estudo observou-se que a cepa M1 foi a mais freqüentemente isolada (20\%), seguida de M87, M22, M12 e M77. Os resultados obtidos são compatíveis aos observados em estudos realizados em diversos países, particularmente nos EUA (Steer et al, 2009). 
Este estudo é muito importante, pois os resultados obtidos são representativos da distribuição das principais cepas de $S$. pyogenes isoladas de pacientes com infecções invasivas e não invasivas tratadas no HC-FMUSP o qual recebe pacientes provenientes de diversas localidades do Brasil.

A avaliação da durabilidade da resposta imune humoral apresentada pelos animais imunizados com o StreptInCor, após 12 meses da última imunização mostrou a presença de anticorpos específicos ao StreptlnCor

Considerando que os linfócitos $\mathrm{T}$ auxiliadores ( $\left.\mathrm{T} \mathrm{CD4}{ }^{+}\right)$são cruciais para o desenvolvimento da resposta imunológica adaptativa com mudança na classe de imunoglobulinas para conferir imunidade rápida e efetiva às reexposições ao antígeno, pelas células de memória, procuramos também avaliar a capacidade proliferativa das células esplênicas dos animais imunizados e controles. Apenas a linhagem DQ8 imunizada com o StreptInCor apresentou resposta proliferativa, tanto de linfócitos $C D 4^{+}$quanto $C D 8^{+}$, e essa linhagem foi a que apresentou melhores resultados da resposta humoral. A linhagem DR4 também apresentou resposta celular proliferativa de linfócitos CD8 ${ }^{+}$ específica ao StreptInCor.

O processo de ativação de células T e sua diferenciação em células de memória levam a expressão de determinadas moléculas em sua superfície, que auxiliam em sua migração para determinados sítios do organismo. As expressões destas moléculas permitem dividir as populações em não reativa (naïve), de memória central e de memória efetora. As moléculas L-Selectina (CD62L), presentes em linfócitos "naïve", se ligam às vênulas do endotélio alto, presente nos linfonodos e permitem a sua entrada nos órgãos linfóides 
secundários, onde serão ativados após sua interação com as células apresentadoras de antígenos, desta forma os linfócitos passarão a expressar outras moléculas como CD44, que é um marcador de linfócitos T ativados e de memória efetora, que favorece a migração dessas células para um determinado sítio inflamatório. As células de memória central expressam tanto a molécula CD62L quanto CD44, e tem a função de desencadear resposta imunológica específica, com maior intensidade, aos antígenos encontrados no interior de órgãos linfóides secundários (Gerberick et al, 1997). Em nossos experimentos, a análise do padrão celular após a proliferação mostrou prevalência de células T CD4 ${ }^{+}$de memória efetora (CD44 $\left.{ }^{+} \mathrm{CD} 62 \mathrm{~L}^{-}\right)$, apenas nas linhagens DR4 e DQ8 e células T CD8 ${ }^{+}$de memória efetora (CD44 $\left.{ }^{+} \mathrm{CD}_{2} \mathrm{~L}^{-}\right)$em todas as linhagens avaliadas (DR4, DQ6 e DQ8), esse padrão foi observado nos grupos que foram imunizados com o StreptlnCor após a estimulação dos esplenócitos com $50 \mu \mathrm{g}$ do mesmo antígeno. Os animais da linhagem DR2 não foram utilizados nestes experimentos devido a deficiências na procriação, durante o desenvolvimento do projeto, conforme descrito.

O grande desafio em se produzir uma vacina contra o $S$. pyogenes é não induzir resposta auto-imune. Para avaliar a segurança da vacina "in vitro", verificamos se havia resposta cruzada entre os anticorpos anti-StreptInCor e a miosina cardíaca, que é a principal proteína cardíaca e que possui diversos epítopos de reação cruzada reconhecidos por anticorpos e linfócitos $T$ de pacientes portadores de FR e DRC (Faé et al, 2006). Em modelo animal, GALVIN et al (2002), mostraram que diferentes regiões da miosina parecem estar relacionadas com a indução de miocardite e valvulite em ratos. Assim, o fragmento S2 da miosina produziu miocardite em ratos, além de induzir 
valvulite. Por outro lado, diferentes regiões da cadeia leve da miosina (LMM) foram capazes de induzir valvulite (resíduos de aminoácidos entre 1685 e 1936, peptídeos sintéticos LMM-31 até LMM-49) ou miocardite (resíduos 1529 até 1611, representados pelos peptídeos LMM-19 até LMM-24). Em nossos experimentos não observamos reatividade cruzada contra a miosina cardíaca integral, em ensaios imunoenzimáticos após a imunização com o StreptInCor.

Outro dado favorável à segurança da imunização com o StreptInCor foi a ausência de sinais de miocardite e/ou valvulite nestes camundongos, quando observados os cortes histológicos do coração destes animais, bem como não foi observado nenhum tipo de sinal patológico nos diferentes órgãos avaliados que pudessem ser atribuídos ao agente vacinal.

O fato de observarmos grande variação na intensidade da resposta humoral entre camundongos imunizados com StreptlnCor nos levou a considerar que, apesar dos transgenes estarem presentes nos animais estudados, as respectivas moléculas poderiam estar ausentes na superfície das células. Portanto, pesquisamos a expressão das moléculas DQ e DR nas células dos camundongos transgênicos. As linhagens DR2, DQ6 e DQ8 apresentaram elevada porcentagem de moléculas HLA-Il presentes na superfície de macrófagos, principalmente, e uma porcentagem menor na superfície de células dendríticas. Apenas a linhagem DR4 apresentou porcentagem muito baixa de HLA de classe II na superfície de células dendríticas. Interessantemente a presença dessas moléculas em maior ou menor quantidade não se correlacionava ao título de anticorpos encontrados nos ensaios de ELISA, ou seja, mesmo animais que apresentavam baixa 
porcentagem de moléculas na superfície mostravam altos títulos de anticorpos, assim como animais com alta porcentagem de moléculas apresentavam baixos títulos de anticorpos. Diante desse resultado, verificamos a possibilidade da ocorrência de produção de moléculas de MHC de classe II quiméricas, contendo uma cadeia alfa ou beta do $\mathrm{H} 2$ murina que se ligaria a uma cadeia complementar da molécula HLA de classe II, que poderia justificar resposta imunológica variável. Apesar dos camundongos utilizados terem uma deleção para os genes que codificam as cadeias Aa e E $\beta$, do MHC-II murino, os genes que codificam as cadeias $A \beta$ e Ea ainda estão presentes, estando apenas silenciados, portando poderiam ter voltado a serem expressos, em algum momento, devido aos vários acasalamentos. No entanto, os resultados obtidos comprovam a total ausência de artefatos da moléculas de MHC de classe II murinas (IA e IE).

Frente a variabilidade da resposta imune humoral encontrada após a imunização com o StreptlnCor adsorvido em hidróxido de alumínio, que induz classicamente uma resposta do tipo Th2, decidimos usar um adjuvante diferente, que fosse capaz de induzir resposta imune do tipo Th1. Devido a seu grande efeito imunoestimulante, o adjuvante de Freund tem sido utilizado extensivamente em vacinas experimentais, tanto por sua capacidade de induzir respostas do tipo celular (Th1) como humoral, com produção de anticorpos (Cox \& Coulter, 1997). A formulação básica do adjuvante de Freund é uma emulsão de água em óleo mineral (Adjuvante Incompleto de Freund - AIF) a qual pode ter seu efeito imunoestimulante aumentado quando se adiciona Mycobacterium ssp. inativado (Adjuvante Completo de Freund - ACF). No entanto os resultados com a utilização de adjuvante de Freund foram 
semelhantes aos obtidos com hidróxido de alumínio, uma vez que as linhagens DR2, DR4 e DQ6 apresentaram animais que não foram capazes de produzir anticorpos após a imunização com o StreptInCor na presença do adjuvante de Freund. Estes dados sugerem que as diferenças observadas da resposta entre as linhagens de camundongos transgênicos não se deve exclusivamente ao hidróxido de alumínio, e podem ser atribuídas a deficiências relacionadas à apresentação antigênica e repertório de células T.

O fato de não observamos diferenças da resposta imune, quando comparamos os adjuvantes, nos levou a avaliar a resposta destes animais frente a uma proteína maior e mais complexa que o StreptlnCor. Para tal, os animais transgênicos que previamente haviam sido imunizados com StreptInCor (6 kDa), foram imunizados com ovalbumina (OVA, 43 kDa) ambos adsorvidos ao hidróxido de alumínio e a resposta também foi altamente variável entre os animais de uma mesma linhagem e entre elas. Mais além, não foi observada correlações entre as imunizações em um mesmo animal, ou seja, animais que obtiveram alto título de anticorpos quando imunizados com o StreptInCor apresentaram baixos títulos de anticorpos quando imunizados com OVA e vice-versa. Estes dados indicam que a reposta variável observada dentro dos grupos experimentais não está relacionada com o nosso agente vacinal, mas sim com o repertório imunológico que estes animais desenvolvem, na presença das moléculas transgênicas.

Um ponto importante a ser ressaltado é que os animais transgênicos, inevitavelmente, têm uma quantidade menor de moléculas MHC-Il expressas na superfície dos monócitos / células dendríticas, uma vez que eles 
apresentam apenas um alelo MHC-II, a do transgene, enquanto um camundongo normal apresentaria dois alelos provenientes dos “Ioci" IA e IE. Há ainda o fato que toda resposta imunológica é desencadeada por uma molécula MHC-II xenogênica, enquanto que as moléculas acessórias responsáveis pela sinalização e estabelecimento de uma resposta imune eficaz são murinas. Isso nos leva a crer que durante o processo de seleção e maturação do repertório linfocitário, no interior do timo em alguns camundongos, ocorra um distúrbio que leva a deficiência em sua habilidade de desenvolver uma resposta imune eficaz. Este processo poderia justificar o fato da resposta imunológica de alguns animais ser discrepante e, possivelmente responsável pela baixa resposta em relação aos camundongos "inbred" (BALB/c e C57BI/6) e "outbred" (Swiss).

O conjunto dos resultados obtidos neste trabalho sugerem que o StreptInCor é um bom indutor de resposta imunológica, principalmente do tipo humoral, com a produção de anticorpos específicos, que também são capazes de reconhecer uma cepa de $S$. pyogenes heteróloga àquela em que sua seqüência foi baseada. Esses anticorpos não apresentam reconhecimento cruzado com a miosina cardíaca ou capacidade de desencadear uma resposta imune deletéria, principalmente naqueles órgãos e tecidos acometidos durante episódios de infecções estreptocócicas e suas complicações, conforme foi visto nos ensaios imunoenzimáticos e nas análises histopatológicas, respectivamente. Por fim, esses resultados são enaltecidos por terem sido produzidos em um modelo experimental, cujo processo de desencadeamento da resposta imune foi totalmente mediado por uma molécula HLA de classe II. 


\section{Conclusões}




\section{Conclusão Geral}

O StreptInCor apresentou boa capacidade imunogênica no contexto de quatro moléculas de HLA de classe II transgênicas diferentes, ao analisar a resposta imune humoral (DR2, DR4, DQ6 e DQ8), e uma resposta celular satisfatória nas 3 linhagens estudadas (DR4, DQ6 e DQ8). Os estudos histopatológicos mostraram que seu uso é seguro, uma vez que não foram observados sinais patológicos ou danos teciduais, desencadeados pela sua administração, nos diversos cortes histológicos dos órgãos desses animais.

\section{Pontos Relevantes}

1 - A administração do StreptlnCor, na presença de hidróxido de alumínio, foi capaz de induzir a produção de anticorpos específicos contra o mesmo peptídeo, os quais continuaram a ser detectados após um longo período, fato observado em animais imunizados das linhagens transgênicas para DR2, DR4, DQ6 e DQ8;

2 - Dentre as imunoglobulinas reativas contra o StreptInCor, o isotipo IgG1 foi predominante nos animais DR2, DR4, DQ6 e DQ8 imunizados com o StreptInCor. Esta constatação está de acordo com os protocolos de imunização que utilizam o hidróxido de alumínio como adjuvante, que induz a produção de IL-4.

3 - O soro dos animais imunizados com o peptídeo foi capaz de reagir contra a proteína M1 heteróloga, indicando a capacidade de reconhecimento de epítopos presentes em proteína $\mathrm{M}$ diferente da utilizada nos estudos e 
delineamento do StreptInCor (proteína M5), e mostra que o mesmo pode induzir uma proteção contra S. pyogenes de diferentes sorotipos.

4 - Os esplenócitos dos camundongos, das linhagens DR4 e DQ8, imunizados com o StreptlnCor foram capazes de proliferarem quando estimulados com $50 \mu \mathrm{g}$ do mesmo antígeno e a análise do padrão das células que proliferaram mostrou uma prevalência de células de memória efetora.

5 - Foi constatado que os camundongos estudados além de apresentarem o transgene HLA-Il também expressavam as moléculas na superfície de suas APC's. Foi descartada a possibilidade da geração de uma molécula quimérica de MHC-II.

6 - Não observamos indícios de resposta cruzada contra a miosina cardíaca em nenhum soro testado, em ensaios de ELISA. Estudos histopatológicos efetuados até o momento mostraram que a administração do StreptInCor não induziu resposta auto-imune. Também não foram observados sinais de toxicidade ou danos teciduais ocasionados pela administração do StreptInCor nos camundongos transgênicos (DR2, DR4, DQ6 e DQ8). 
Anexos 
Anexo A - Aprovação do Comitê de Ética IMT-SP

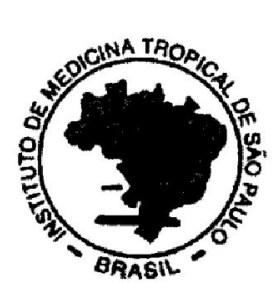

UNIVERSIDADE DE SÃO PAULO INSTITUTO DE MEDICINA TROPICAL DE SÃO PAULO

Av. Dr. Enéas de Carvalho Aguiar, 470

CEP 05403-000 - São Paulo - Brasil

Telefone:(55-11)3061-7066 e 3064-5132

3062-2174

FAX: (55-11) 3064-5132 e

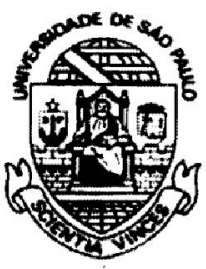

São Paulo, 15 de setembro de 2008.

IImo (a)

Sr (a) Milton Thiago Guerino Silva

Em reunião na presente data, o Comitê de Ética em Pesquisa do Instituto de Medicina Tropical de São Paulo da Universidade de São Paulo analisou e aprovou, no que diz respeito aos aspectos de natureza da ética em experimentação animal, o projeto de pesquisa classificado sob número CEPIMT/019/24072008 e intitulado "Avaliação de potencial agente vacinal contra o S.pyogenes em camundongos transgênicos, portadores de genes HLA de classe II humanos" sob a responsabilidade da Dra.Luiza Guilherme Guglielmi.

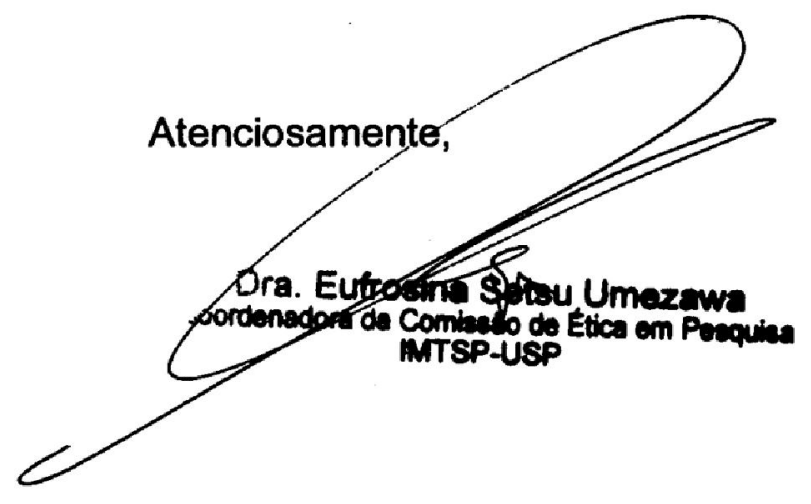




\section{Referências Bibliográficas}


Abdel-Aal AB, Zaman M, Fujita Y, Batzloff MR, Good MF, Toth I (2010) Design of three-component vaccines against group A streptococcal infections: importance of spatial arrangement of vaccine components. J Med Chem 53: 8041-8046

Anastasiou-Nana MI, Anderson JL, Carlquist JF, Nanas JN (1986) HLA-DR typing and lymphocyte subset evaluation in rheumatic heart disease: a search for immune response factors. Am Heart $J$ 112: 992-997

Beachey EH, Seyer JM, Dale JB (1987) Protective immunogenicity and T lymphocyte specificity of a trivalent hybrid peptide containing $\mathrm{NH}$-terminal sequences of types 5,6 , and $24 \mathrm{M}$ proteins synthesized in tandem. $J$ Exp Med 166: 647-656

Bessen D, Fischetti VA (1988a) Influence of intranasal immunization with synthetic peptides corresponding to conserved epitopes of $M$ protein on mucosal colonization by group A streptococci. Infect Immun 56: 2666-2672

Bessen D, Fischetti VA (1988b) Passive acquired mucosal immunity to group A streptococci by secretory immunoglobulin A. J Exp Med 167: 1945-1950

Bessen D, Fischetti VA (1990) Synthetic peptide vaccine against mucosal colonization by group A streptococci. I. Protection against a heterologous $M$ serotype with shared C repeat region epitopes. J Immunol 145: 1251-1256

Bisno AL (2001) Acute pharyngitis. N Engl J Med 344: 205-211

Bradley DS, Nabozny GH, Cheng S, Zhou P, Griffiths MM, Luthra HS, David CS (1997) HLA-DQB1 polymorphism determines incidence, onset, and severity of collagen-induced arthritis in transgenic mice. Implications in human rheumatoid arthritis. J Clin Invest 100: 2227-2234

Carapetis JR, Steer AC, Mulholland EK, Weber M (2005) The global burden of group A streptococcal diseases. Lancet Infect Dis 5: 685-694

Cardiologia SBd (2009) [Brazilian guidelines for the diagnosis, treatment and prevention of rheumatic fever]. Arq Bras Cardiol 93: 3-18

Cheng S, Smart M, Hanson J, David CS (2003) Characterization of HLA DR2 and DQ8 transgenic mouse with a new engineered mouse class II deletion, which lacks all endogenous class II genes. J Autoimmun 21: 195-199

Chopra P, Narula J, Kumar AS, Sachdeva S, Bhatia ML (1988) Immunohistochemical characterisation of Aschoff nodules and endomyocardial inflammatory infiltrates in left atrial appendages from patients with chronic rheumatic heart disease. Int J Cardiol 20: 99-105

Cox JC, Coulter AR (1997) Adjuvants--a classification and review of their modes of action. Vaccine 15: 248-256 
Cunningham MW (2000) Pathogenesis of group A streptococcal infections. Clin Microbiol Rev 13: 470-511

Dale JB (1999a) Group A streptococcal vaccines. Infect Dis Clin North Am 13: 227-243, viii

Dale JB (1999b) Multivalent group A streptococcal vaccine designed to optimize the immunogenicity of six tandem M protein fragments. Vaccine 17: 193-200

Dale JB, Beachey EH (1986) Sequence of myosin-crossreactive epitopes of streptococcal M protein. J Exp Med 164: 1785-1790

Dale JB, Chiang EY, Lederer JW (1993) Recombinant tetravalent group A streptococcal M protein vaccine. J Immunol 151: 2188-2194

Dale JB, Chiang EY, Liu S, Courtney HS, Hasty DL (1999) New protective antigen of group A streptococci. J Clin Invest 103: 1261-1268

Edelman R (1980) Vaccine adjuvants. Rev Infect Dis 2: 370-383

Eroglu GE, Kohler PF (2002) Familial systemic lupus erythematosus: the role of genetic and environmental factors. Ann Rheum Dis 61: 29-31

Faé KC, da Silva DD, Oshiro SE, Tanaka AC, Pomerantzeff PM, Douay C, Charron D, Toubert A, Cunningham MW, Kalil J, Guilherme L (2006) Mimicry in recognition of cardiac myosin peptides by heart-intralesional $\mathrm{T}$ cell clones from rheumatic heart disease. J Immunol 176: 5662-5670

Fernandes AP, Louzada-Junior P, Foss MC, Donadi EA (2002) HLA-DRB1, DQB1, and DQA1 allele profile in Brazilian patients with type 1 diabetes mellitus. Ann N Y Acad Sci 958: 305-308

Fischetti VA (1989) Streptococcal M protein: molecular design and biological behavior. Clin Microbiol Rev 2: 285-314

Fischetti VA, Hodges WM, Hruby DE (1989) Protection against streptococcal pharyngeal colonization with a vaccinia: M protein recombinant. Science 244: $1487-1490$

Galvin JE, Hemric ME, Kosanke SD, Factor SM, Quinn A, Cunningham MW (2002) Induction of myocarditis and valvulitis in lewis rats by different epitopes of cardiac myosin and its implications in rheumatic carditis. $A m \mathrm{~J}$ Pathol 160: 297-306

Gerberick GF, Cruse LW, Miller CM, Sikorski EE, Ridder GM (1997) Selective modulation of $\mathrm{T}$ cell memory markers CD62L and CD44 on murine draining lymph node cells following allergen and irritant treatment. Toxicol Appl Pharmacol 146: 1-10 
Germain RN, Jenkins MK (2004) In vivo antigen presentation. Curr Opin Immunol 16: 120-125

Gonzalez-Gay MA, Zanelli E, Khare SD, Krco CJ, Zhou P, Inoko H, Griffiths MM, Luthra HS, David CS (1996) Human leukocyte antigen-DRB1*1502 (DR2Dw12) transgene reduces incidence and severity of arthritis in mice. Hum Immunol 50: 54-60

Grinberg M, Mansur AJ, Snitcowsky R, Ebaid M, Décourt LV, Pileggi F (1985) [Infectious endocarditis in young patients]. Arq Bras Cardiol 44: 87-91

Guilherme L, Alba MP, Ferreira FM, Oshiro SE, Higa F, Patarroyo ME, Kalil J (2011) Anti-group A streptococcal vaccine epitope: structure, stability, and its ability to interact with HLA class II molecules. J Biol Chem 286: 6989-6998

Guilherme L, Cury P, Demarchi LM, Coelho V, Abel L, Lopez AP, Oshiro SE, Aliotti S, Cunha-Neto E, Pomerantzeff PM, Tanaka AC, Kalil J (2004) Rheumatic heart disease: proinflammatory cytokines play a role in the progression and maintenance of valvular lesions. Am J Pathol 165: 15831591

Guilherme L, Dulphy N, Douay C, Coelho V, Cunha-Neto E, Oshiro SE, Assis RV, Tanaka AC, Pomerantzeff PM, Charron D, Toubert A, Kalil J (2000) Molecular evidence for antigen-driven immune responses in cardiac lesions of rheumatic heart disease patients. Int Immunol 12: 1063-1074

Guilherme L, Faé KC, Higa F, Chaves L, Oshiro SE, Freschi de Barros S, Puschel C, Juliano MA, Tanaka AC, Spina G, Kalil J (2006) Towards a vaccine against rheumatic fever. Clin Dev Immunol 13: 125-132

Guilherme L, Faé KC, Oshiro SE, Tanaka AC, Pomerantzeff PM, Kalil J (2007a) $T$ cell response in rheumatic fever: crossreactivity between streptococcal M protein peptides and heart tissue proteins. Curr Protein Pept Sci 8: 39-44

Guilherme L, Postol E, Freschi de Barros S, Higa F, Alencar R, Lastre M, Zayas C, Puschel CR, Silva WR, Sa-Rocha LC, Sa-Rocha VM, Pérez O, Kalil J (2009) A vaccine against $S$. pyogenes: design and experimental immune response. Methods 49: 316-321

Guilherme L, Ramasawmy R, Kalil J (2007b) Rheumatic fever and rheumatic heart disease: genetics and pathogenesis. Scand J Immunol 66: 199-207

Guilherme L, Weidebach W, Kiss MH, Snitcowsky R, Kalil J (1991) Association of human leukocyte class II antigens with rheumatic fever or rheumatic heart disease in a Brazilian population. Circulation 83: 1995-1998

Gupta RK, Siber GR (1995) Adjuvants for human vaccines--current status, problems and future prospects. Vaccine 13: 1263-1276 
Hu MC, Walls MA, Stroop SD, Reddish MA, Beall B, Dale JB (2002) Immunogenicity of a 26 -valent group A streptococcal vaccine. Infect Immun 70: 2171-2177

Hunter RL (2002) Overview of vaccine adjuvants: present and future. Vaccine 20 Suppl 3: S7-12

Ishimoto T, Yamamoto K, Fukui Y, Fukuda Y, Dohi K, Sasazuki T (1997) In vitro and in vivo evidence for high frequency of I-Ab-reactive CD4+ T cells in HLADQ or HLA-DRA transgenic mice lacking endogenous MHC class I and/or class II expression. J Immunol 159: 3717-3722

Jones KF, Khan SA, Erickson BW, Hollingshead SK, Scott JR, Fischetti VA (1986) Immunochemical localization and amino acid sequences of crossreactive epitopes within the group A streptococcal M6 protein. J Exp Med 164: 1226-1238

KAPLAN MH (1963) Immunologic relationship of group A streptococcal strains and human heart tissue. Possible significance for the pathogenesis of rheumatic fever. Am Heart J 65: 426-427

Kaur S, Kumar D, Grover A, Khanduja KL, Kaplan EL, Gray ED, Ganguly NK (1998) Ethnic differences in expression of susceptibility marker(s) in rheumatic fever/rheumatic heart disease patients. Int J Cardiol 64: 9-14

Kemeny E, Grieve T, Marcus R, Sareli P, Zabriskie JB (1989) Identification of mononuclear cells and $\mathrm{T}$ cell subsets in rheumatic valvulitis. Clin Immunol Immunopathol 52: 225-237

Kraus W, Dale JB, Beachey EH (1990) Identification of an epitope of type 1 streptococcal $M$ protein that is shared with a $43-\mathrm{kDa}$ protein of human myocardium and renal glomeruli. J Immunol 145: 4089-4093

Kraus W, Ohyama K, Snyder DS, Beachey EH (1989a) Autoimmune sequence of streptococcal $M$ protein shared with the intermediate filament protein, vimentin. J Exp Med 169: 481-492

Kraus W, Seyer JM, Beachey EH (1989b) Vimentin-cross-reactive epitope of type 12 streptococcal M protein. Infect Immun 57: 2457-2461

LANCEFIELD RC (1962) Current knowledge of type-specific $M$ antigens of group A streptococci. J Immunol 89: 307-313

Lawrance SK, Karlsson L, Price J, Quaranta V, Ron Y, Sprent J, Peterson PA (1989) Transgenic HLA-DR alpha faithfully reconstitutes IE-controlled immune functions and induces cross-tolerance to $E$ alpha in $E$ alpha 0 mutant mice. Cell 58: 583-594 
Madsen L, Labrecque N, Engberg J, Dierich A, Svejgaard A, Benoist C, Mathis $D$, Fugger $L$ (1999) Mice lacking all conventional MHC class II genes. Proc Natl Acad Sci U S A 96: 10338-10343

Maharaj B, Hammond MG, Appadoo B, Leary WP, Pudifin DJ (1987) HLA-A, B, $\mathrm{DR}$, and $\mathrm{DQ}$ antigens in black patients with severe chronic rheumatic heart disease. Circulation 76: 259-261

Mosmann TR, Coffman RL (1989) Heterogeneity of cytokine secretion patterns and functions of helper T cells. Adv Immunol 46: 111-147

Nabozny GH, Baisch JM, Cheng S, Cosgrove D, Griffiths MM, Luthra HS, David CS (1996) HLA-DQ8 transgenic mice are highly susceptible to collageninduced arthritis: a novel model for human polyarthritis. J Exp Med 183: 2737

O'Hagan DT, Rappuoli R (2006) Novel approaches to pediatric vaccine delivery. Adv Drug Deliv Rev 58: 29-51

Olive C, Schulze K, Sun HK, Ebensen T, Horváth A, Toth I, Guzman CA (2007) Enhanced protection against Streptococcus pyogenes infection by intranasal vaccination with a dual antigen component M protein/Sfbl lipid core peptide vaccine formulation. Vaccine 25: 1789-1797

Olmez U, Turgay M, Ozenirler S, Tutkak H, Düzgün N, Duman M, Tokgöz G (1993) Association of HLA class I and class II antigens with rheumatic fever in a Turkish population. Scand J Rheumatol 22: 49-52

Pan S, Trejo T, Hansen J, Smart M, David CS (1998) HLA-DR4 (DRB1*0401) transgenic mice expressing an altered CD4-binding site: specificity and magnitude of DR4-restricted T cell response. J Immunol 161: 2925-2929

Rajapakse CN, Halim K, Al-Orainey I, Al-Nozha M, Al-Aska AK (1987) A genetic marker for rheumatic heart disease. Br Heart J 58: 659-662

RAMON G (1955) [The principle of adjuvant and stimulant substances of immunity; its bases; its applications]. C R Hebd Seances Acad Sci 241: 781784

Relf WA, Cooper J, Brandt ER, Hayman WA, Anders RF, Pruksakorn S, Currie B, Saul A, Good MF (1996) Mapping a conserved conformational epitope from the M protein of group A streptococci. Pept Res 9: 12-20

Ribeiro SP, Rosa DS, Fonseca SG, Mairena EC, Postól E, Oliveira SC, Guilherme L, Kalil J, Cunha-Neto E (2010) A vaccine encoding conserved promiscuous HIV CD4 epitopes induces broad $\mathrm{T}$ cell responses in mice transgenic to multiple common HLA class II molecules. PLoS One 5: e11072 
Roberts S, Kosanke S, Terrence Dunn S, Jankelow D, Duran CM, Cunningham MW (2001) Pathogenic mechanisms in rheumatic carditis: focus on valvular endothelium. J Infect Dis 183: 507-511

Rosenthal AS, Shevach EM (1973) Function of macrophages in antigen recognition by guinea pig T Iymphocytes. I. Requirement for histocompatible macrophages and lymphocytes. J Exp Med 138: 1194-1212

Sargent SJ, Beachey EH, Corbett CE, Dale JB (1987) Sequence of protective epitopes of streptococcal $M$ proteins shared with cardiac sarcolemmal membranes. J Immunol 139: 1285-1290

Schirmbeck R, Melber K, Kuhröber A, Janowicz ZA, Reimann J (1994) Immunization with soluble hepatitis $B$ virus surface protein elicits murine $\mathrm{H}-2$ class I-restricted CD8+ cytotoxic T lymphocyte responses in vivo. J Immunol 152: $1110-1119$

Shulman ST, Tanz RR, Dale JB, Beall B, Kabat W, Kabat K, Cederlund E, Patel D, Rippe J, Li Z, Sakota V, Group NASPS (2009) Seven-year surveillance of north american pediatric group a streptococcal pharyngitis isolates. Clin Infect Dis 49: 78-84

Singh M, O'Hagan D (1999) Advances in vaccine adjuvants. Nat Biotechnol 17: 1075-1081

Smeesters PR, McMillan DJ, Sriprakash KS (2010) The streptococcal M protein: a highly versatile molecule. Trends Microbiol 18: 275-282

SNELL GD, WHEELER N, AARON M (1957) A new method of typing inbred strains of mice for histocompatibility antigens. Transplant Bull 4: 18-21

Snitcowsky R (1996) Rheumatic fever prevention in industrializing countries: problems and approaches. Pediatrics 97: 996-998

Steer AC, Danchin MH, Carapetis JR (2007) Group A streptococcal infections in children. J Paediatr Child Health 43: 203-213

Stewart-Tull DE (2003) Adjuvant formulations for experimental vaccines. Methods Mol Med 87: 175-194

Trembleau S, Giacomini P, Guéry JC, Setini A, Hammer J, Sette A, Appella E, Adorini L (1995) DR alpha: $E$ beta heterodimers in DRA transgenic mice hinder expression of $E$ alpha: $E$ beta molecules and are more efficient in antigen presentation. Int Immunol 7: 1927-1938

Weidebach W, Goldberg AC, Chiarella JM, Guilherme L, Snitcowsky R, Pileggi F, Kalil J (1994) HLA class II antigens in rheumatic fever. Analysis of the DR locus by restriction fragment-length polymorphism and oligotyping. Hum Immunol 40: 253-258 


\title{
HLA class II transgenic mice develop a safe and long lasting immune response against StreptInCor, an anti-group A streptococcus vaccine candidate
}

\author{
Milton T. Guerino a,b,1, Edilberto Postol a,b,1 , Lea M.F. Demarchi ${ }^{\mathrm{a}}$, Carlo O. Martins ${ }^{\mathrm{a}, \mathrm{b}}$, \\ Luiz R. Mundel ${ }^{\mathrm{d}}$, Jorge Kalil ${ }^{\mathrm{a}, \mathrm{b}, \mathrm{c}}$, Luiza Guilherme ${ }^{\mathrm{a}, \mathrm{b}, *}$ \\ ${ }^{a}$ Heart Institute (InCor), School of Medicine, University of São Paulo, São Paulo, Brazil \\ ${ }^{\mathrm{b}}$ Immunology Investigation Institute, National Institute for Science and Technology, University of São Paulo, São Paulo, Brazil \\ c Clinical Immunology and Allergy Division, School of Medicine, University of São Paulo, São Paulo, Brazil \\ d School of Medicine, University of São Paulo, São Paulo, Brazil
}

\section{A R T I C L E I N F O}

\section{Article history:}

Received 18 July 2011

Received in revised form 24 August 2011

Accepted 28 August 2011

Available online 9 September 2011

\section{Keywords:}

S. pyogenes

Vaccine

HLA class II transgenic mice

Humoral immune response

Histopathology

\begin{abstract}
A B S T R A C T
Streptococcus pyogenes infections remain a health problem in several countries because of poststreptococcal sequelae, such as rheumatic fever and rheumatic heart disease. We developed a vaccine epitope (StreptInCor) composed of 55 amino acid residues of the C-terminal portion of the M protein that encompasses both $\mathrm{T}$ and B cell protective epitopes. Recently, by using human blood samples, we showed that the StreptInCor epitope is able to bind to different HLA class II molecules and that it could be considered a universal vaccine epitope. In the present work, we evaluated the immune response of HLA class II transgenic mice against aluminum hydroxide-absorbed StreptInCor. After a period of one year, several organs were analyzed histologically to verify the safety of the candidate vaccine epitope. Our results showed that StreptInCor is able to induce robust and safe and long lasting immune response without deleterious reactions in several organs. In conclusion, the results presented here indicate that StreptInCor could be considered a safe vaccine against severe streptococcus-induced diseases.
\end{abstract}

(c) 2011 Elsevier Ltd. All rights reserved.

\section{Introduction}

Group A streptococci (GAS) are responsible for several human diseases, such as pharyngitis. These diseases may lead to post-streptococcal sequelae, including autoimmune disorders glomerulonephritis and rheumatic fever (RF). Non-autoimmune post-streptococcal sequelae that are caused by the cutaneous infections include necrotizing fasciitis and toxic shock syndrome.

The global incidence of diseases caused by GAS is not clearly resolved. In developing countries, many cases go untreated, and consequently, the health system is not notified. Although the estimates are misinformed, it is estimated that there are more than 15 million people around the world with rheumatic heart disease (RHD), the most severe sequel of RF. An estimated 300,000 new cases of RHD occur each year, and over 200,000 deaths caused by RHD each year [1]. The Brazilian public health system spent over 90 million U.S. dollars for treatment of RF and RHD patients. Furthermore, $31 \%$ of all cardiac surgeries in children are related to $\mathrm{RF}$,

\footnotetext{
* Corresponding author at: Luiza Guilherme, Laboratório de Imunologia, Instituto do Coração (HC-FMUSP), Av. Dr. Eneas de Carvalho Aguiar, 44, 05403-000 São Paulo, SP, Brazil. Tel.: +55 113069 5901; fax: +55 1130695953 .

E-mail address: luizagui@usp.br (L. Guilherme).

1 Both are considered as first author.
}

which is also responsible for $7.5 \%$ mortality per year. Finally, it is estimated that Brazil has over 10 million cases of throat infections caused by Streptococci that lead to 30,000 new cases of RF each year [2].

The M protein is the major virulence factor of GAS. The M protein involves bacterial adhesion, evasion, and promotes immune responses to GAS because of its immunogenicity [3]. It is composed of $\mathrm{N}$ and $\mathrm{C}$-terminal portions; the $\mathrm{N}$-terminal region is hypervariable and highly immunogenic whereas the C-terminal region is highly conserved among the most GAS strains. The mechanisms leading to RF and RHD involve a cross-reaction between the $\mathrm{N}$ terminal region of the alpha-helical coiled-coil $\mathrm{M}$ protein and self-proteins, mainly cardiac proteins. Accordingly, the homology between the $M$ protein and human proteins myosin, tropomyosin, keratin [4] and fibrillar collagen, the major component of heart valves [5], could be involved with the autoimmune response by the molecular mimicry mechanism [6-11]. In other words, the production of cross-reactive antibodies raised against GAS could be specifically within cardiac tissue, which would lead to an increased expression of the adhesion molecule VCAM-I [12] that facilitate the lymphocytic infiltration through the valve surface endothelium. This mechanism appears to be the initiating step for tissue damage and disease pathogenesis [12]. Both streptococcal primed $\mathrm{CD}^{+}$and $\mathrm{CD}^{+} \mathrm{T}$ lymphocytes are recruited probably under specific chemokine. This scenario might promote enhanced infiltration 
of mononuclear cells to the lesion and the production of inflammatory cytokines, such as IFN- $\gamma$ and TNF- $\alpha$, resulting in further tissue destruction and necrosis [12-14].

The triggering of an autoimmune response involves antigenic presentation by macrophages via human leukocyte antigen-II (HLA-II) molecules to the T cell receptor. These molecules are genetically controlled and some alleles have already been described as being associated with the development of RF/RHD. Briefly, DR2 and DR4 were found in association with individuals in America; DR4, in Saudi Arabia; DR1 and DR6, in South Africa; DR7 and DR11, in Turkey; and DR7 and DR53, in Brazil. It is interesting to note that a DR7 defined molecular approach was also found in Latvians and Egyptians, and this was associated with the worsening of the valve damage [15].

The epidemiological growth of streptococcal diseases and the high treatment costs generated by complications caused by RF have encouraged many groups to study vaccine candidates to prevent GAS infections. Because of the importance and immunogenicity of the $M$ protein in GAS infections, some vaccine models against GAS are being developed that involve different regions of this protein. A vaccine currently under clinical trials is based on the N-terminal region of the $M$ protein and contains sequences from 26 of the most prevalent serotypes of GAS in the USA [16-19]. Additionally, an Australian group has developed a vaccine based on a C-terminal B epitope in the M protein that is conjugated to a universal T epitope and Toll-like receptor target lipoproteins [20].

We have been studying a sequence of amino acids present in the $\mathrm{C}$-terminus of the M protein to develop a subunit vaccine that is able to induce protection against different GAS strains. To define the vaccine epitope, we tested a large panel of approximately 900 sera and peripheral blood mononuclear cell (PBMC) samples that enabled us to identify both $\mathrm{B}$ and $\mathrm{T}$ immunodominant epitopes and then to construct a candidate vaccine composed of 55 of these amino acid residues [21]. Recently, we showed that this vaccine epitope, identified as StreptInCor (medical identity), has three-dimensional structural features that make it recognizable to any HLA class II resulting in $\mathrm{T}$ cell activation and differentiation into effectors and memory cells [22]. Specific antibodies raised against StreptInCor were able to recognize heterologous M1 protein in immunized isogenic mice, which suggests that our candidate vaccine has broad coverage.

MHC-II transgenic mouse models have a complete deletion of murine $\mathrm{H} 2$ molecules [23]. These models are an important approach to study the relationship of HLA-II molecules and autoimmunity [24-27] and therefore could be an important model to study the immune response to vaccines. In the present work, MHC class II transgenic mice carrying human HLA class II alleles were evaluated. HLA DRB1.1502 (DR2), DRB1.0401 (DR4), DQB1.0601 (DQ6) and DQB1.0302 (DQ8) transgenic mice were used to study humoral immune responses after immunization with StreptInCor. These animals were followed for 12 months to monitor the humoral immune responses and safety control. The results presented here showed high titers of specific antibodies, and no signs of tissue damage or autoimmune disorders were observed, indicating that the StreptInCor could be an immunogenic and safe vaccine.

\section{Methods}

\subsection{StreptInCor vaccine epitope}

The vaccine epitope consists of 55 amino acid residues as follows: KGLRRDLDASREAKKQLEAEQQKLEEQNKISEASRKGLRRDLDASREAKKQVEK, as previously described [21] (patents INPI 0501290/0604997-4, PCT-BR07/000184).

\subsection{Mice}

Specific pathogen-free, 6- to 8-week-old HLA-class II DRB1*1502 (DR2), DRB1*0401 (DR4), DQB1*0601(DQ6) and DQB1*0302 (DQ8) transgenic mice were used in this study $[24,25,28]$. All transgenic mice were kindly provided by Dr. Chella S. David (Department of Immunology, Mayo Clinic, Rochester, USA) and were maintained and manipulated in the animal facility of the Tropical Medicine Institute, Medical School, University of São Paulo, Brazil. The mice were housed in autoclaved micro isolator cages (Alesco, Brazil) and manipulated under aseptic conditions. All procedures were performed in accordance with the Brazilian Committee for Animal Care and Use (COBEA) guidelines.

The presence of the HLA-class II transgene in all mice studied was verified by molecular biology techniques using skin biopsies. All mice that did not have the HLA class II transgene were discarded and were not used in this study. We also evaluated the presence of the HLA class II molecules on the surface of antigen presenting cells from the peripheral blood to control for the expression of the specific transgene (data not shown).

\subsection{Immunization}

HLA-class II transgenic mice received two subcutaneous doses $(100 \mu \mathrm{L})$ on days 0 and 14 of a suspension containing $50 \mu \mathrm{g}$ of StreptInCor absorbed onto $300 \mu \mathrm{g}$ of $\mathrm{Al}(\mathrm{OH})_{3}$ (aluminum hydroxide). Animals receiving saline plus adjuvant were used as experimental controls for immunization. Sera samples were obtained from mice on day 28 following immunization while under light anesthesia by retro-orbital puncture.

\subsection{Sera antibody measurement}

Sera antibody titers were determined by ELISA. Briefly, $1 \mu \mathrm{g}$ of StreptInCor vaccine epitope and overlapping peptides, porcine cardiac myosin (Sigma, USA), or M1 recombinant protein (clone kindly provided by Prof Patrick Cleary, University of Minnesota Medical School, MN, USA) produced and purified in our lab, were diluted in coating buffer $(0.05 \mathrm{M}$ carbonate-bicarbonate, $\mathrm{pH}$ 9.6, $50 \mu \mathrm{L} / \mathrm{w}$ ) and was added to a 96-well MaxiSorp assay plate (Nunc, Denmark). After overnight incubation, the plates were blocked with $0.25 \%$ gelatin (Sigma) diluted in 0.05\% Tween-20 (Sigma, USA) in PBS (dilution buffer) for $1 \mathrm{~h}$ at room temperature. Starting at 1/100 in dilution buffer, serial 2-fold dilutions were added to the plates $(50 \mu \mathrm{L} / \mathrm{w})$. After a $2 \mathrm{~h}$ incubation at $37^{\circ} \mathrm{C}$ and three washes $(200 \mu \mathrm{L} / \mathrm{w})$ with $0.05 \%$ Tween 20 in PBS (rinse buffer), the plates were incubated for another hour at $37^{\circ} \mathrm{C}$ with peroxidase-conjugated anti-mouse IgG (Pharmingen, USA) at $1: 2000$ in dilution buffer $(50 \mu \mathrm{L} / \mathrm{w})$. The plates were then washed three times $(200 \mu \mathrm{L} / \mathrm{w})$ with rinse buffer, and the reaction was revealed with $50 \mu \mathrm{L} / \mathrm{w}$ of $0.4 \mathrm{mg} / \mathrm{mL}$ ortophenylenediamine (OPD, Sigma, USA) in $100 \mathrm{mM}$ sodium citrate (Merck, Germany) containing $0.03 \% \mathrm{H}_{2} \mathrm{O}_{2}$ (Merck). After $10 \mathrm{~min}$ at room temperature, the reactions were stopped using $4 \mathrm{~N} \mathrm{H}_{2} \mathrm{SO}_{4}$, and the optical density was evaluated using a $490 \mathrm{~nm}$ ELISA filter in an MR4000 ELISA plate reader (Dynatech, USA). To study IgG isotypes, the biotinylated conjugates anti-mouse IgG1, IgG2a, IgG2b and IgG3 (Pharmingen, USA) were used at $2 \mu \mathrm{g} / \mathrm{mL}(50 \mu \mathrm{L} / \mathrm{w})$ and incubated for $1 \mathrm{~h}$ at $37^{\circ} \mathrm{C}$. After three washes with rinse buffer, the plates were incubated with streptavidin peroxidase (Pharmingen, USA) at $1 / 1000(50 \mu \mathrm{L} / \mathrm{w})$ for $1 \mathrm{~h}$ at $37^{\circ} \mathrm{C}$. Finally, the reaction was finished as described above.

\subsection{Western blot}

Lysate of heart tissue was obtained from post mortem normal human myocardium, separated by $10 \%$ SDS-PAGE and blotted 


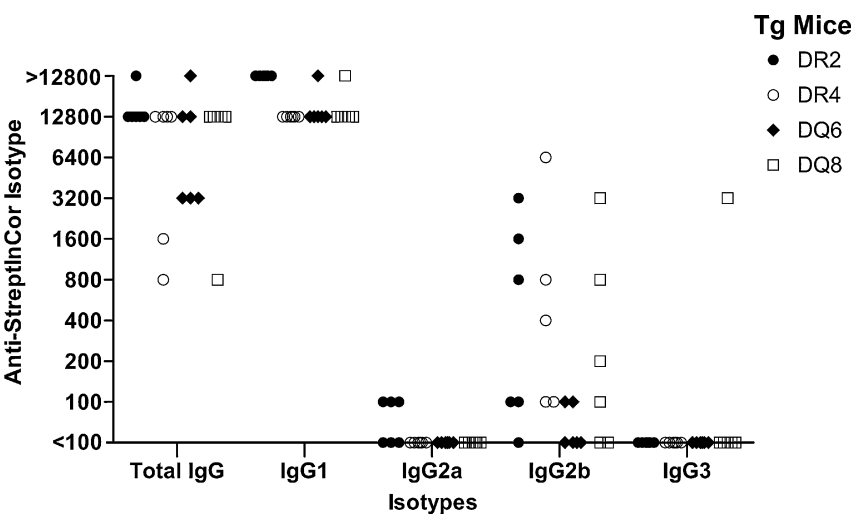

Fig. 1. StreptInCor-reactive IgG isotypes. Sera from HLA class II transgenic mice $(n=6)$ immunized with $50 \mu \mathrm{g}$ of StreptInCor absorbed into $300 \mu \mathrm{g}$ of aluminum hydroxide. The titer obtained for each serum sample is represented as data point. Titers less than 100 are represented as negative values. DR2 transgenic ( $\mathrm{tg}$ ) mice $(\bullet)$; DR4 tg mice (O); DQ6 tg mice ( ), and DQ8 tg mice $(\square)$.

onto nitrocellulose membranes as described [29,30]. The blots were divided into strips and blocked with Tris buffered saline containing $5 \%$ of skim milk. The strips were sequentially treated with a pool of immunized and non-immunized (controls) transgenic mice sera, followed by a treatment with anti-mouse IgG alkaline phosphatase and revealed in the presence of NBT-BCIP solution (Invitrogen, USA). Positive control: mouse anti-porcine myosin serum. Negative control: pre-immune mouse serum.

\subsection{Histopathological analysis}

After 12 months, immunized mice and controls were sacrificed and the heart, liver, spleen, brain, kidney and articulations were collected. The tissues were immediately fixed in PBS containing 10\% formaldehyde, paraffin-processed, and histological sections were evaluated after staining with hematoxylin and eosin (H\&E).

\section{Results}

\subsection{StreptInCor induces high IgG antibody titers}

StreptInCor was able to induce a robust immune response in all HLA class II transgenic mice studied 28 days after immunization. DQ6 and DQ8 transgenic mice presented the highest titers of total $\operatorname{IgG}(>1: 12,800)$ (Fig. 1$)$. We observed variable IgG production among the DR4 transgenic mice $(>1: 800$ and $1: 12,800)$ (Fig. 1). Among the IgG isotypes, IgG1 and IgG2b were induced in all the transgenic mice and IgG3 was only produced in the DQ8 transgenic mice (Fig. 1). Control animals receiving only aluminum hydroxide did not present any reactivity to StreptInCor (data not shown). To verify whether the immune response against StreptInCor was specific, we analyzed the reactivity of the immunized transgenic mice recognize the immunogenic vaccine epitope in the heterologous M1 recombinant (rM1) protein. Our results showed that all DR2, DR4, and DQ8 mice and 3 out of 6 DQ6 mice were reactive against rM1 protein (Fig. 2). It is interesting to note that the levels of antiIgG antibodies against rM1 protein were lower (1:100 to $1: 3200)$ (Fig. 2). Additionally, none of the transgenic mice developed antibodies against either porcine cardiac myosin (Fig. 2) or human myocardium-derived proteins (Fig. 3) indicating the absence of cross-reactivity with cardiac proteins.

All the mice were followed for one year before they were sacrificed. The amount of $\operatorname{IgG}$ was evaluated at $1,4,8$, and 12 months. Our results showed a decreased amount of IgG present in immunized mice after 4 months (Fig. 4), and most of the mice maintained

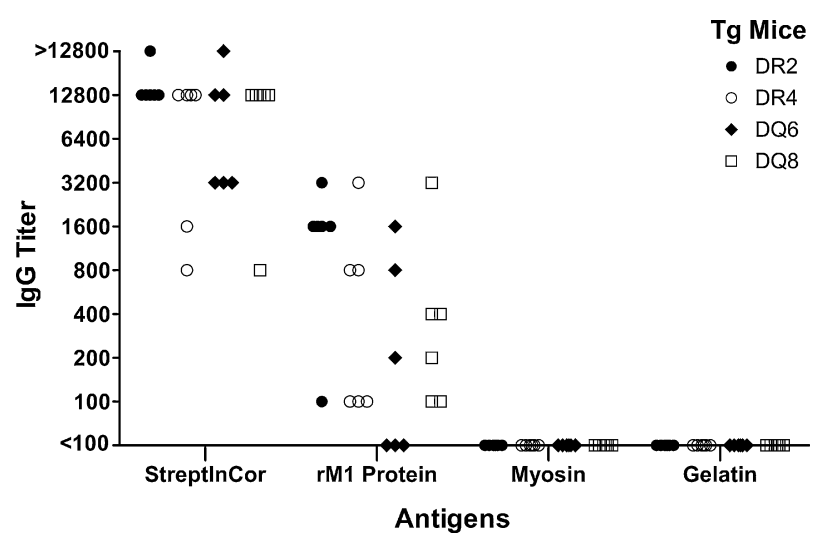

Fig. 2. StreptInCor sequence-specific antibodies recognize heterologous protein and did not display crossreactivity with cardiac myosin. Sera from HLA class II transgenic mice $(n=6)$ immunized with $50 \mu \mathrm{g}$ of StreptInCor absorbed into $300 \mu \mathrm{g}$ of aluminum hydroxide. The titer obtained for each serum sample is represented as data point Titers less than 100 are represented as negative values. DR2 transgenic (tg) mice $(\bullet)$; DR4 tg mice $(\bigcirc)$; DQ6 tg mice $(\diamond)$, and DQ8 tg mice ( $\square)$.

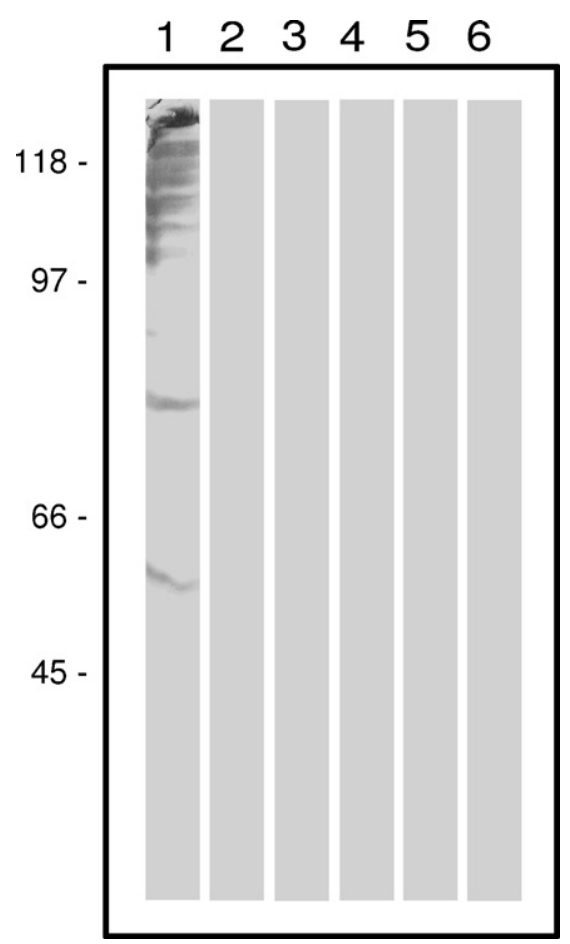

Fig. 3. StreptInCor did not induce heart-tissue proteins cross reactive antibodies. A pool of sera of each lineage of immunized HLA class II transgenic ( $\mathrm{Tg}$ ) mice was tested by Western-blot against normal human-myocardium tissue derived proteins. Lane 1: positive control: polyclonal mouse anti-porcine myosin serum; Lane 2: negative control: non-immunized mouse serum; Lane 3: pool of DR2 Tg-mice $(n=6)$ sera; Lane 4: pool of DR4 Tg-mice $(n=6)$ sera; Lane 5: pool of DQ6 Tg-mice $(n=6)$ sera; Lane 6: pool of DQ8 Tg-mice $(n=6)$ sera.

low reactivity IgG titers until 1 year post-immunization (Fig. 4).

\subsection{Immunized HLA class II transgenic mice recognize StreptInCor overlapping peptides}

We analyzed the humoral immune response of HLA class II Tgmice against 8 StreptInCor-derived overlapping peptides that cover the entire vaccine epitope sequence and encompassed the possibilities of processing and presentation by antigen-presenting cells 

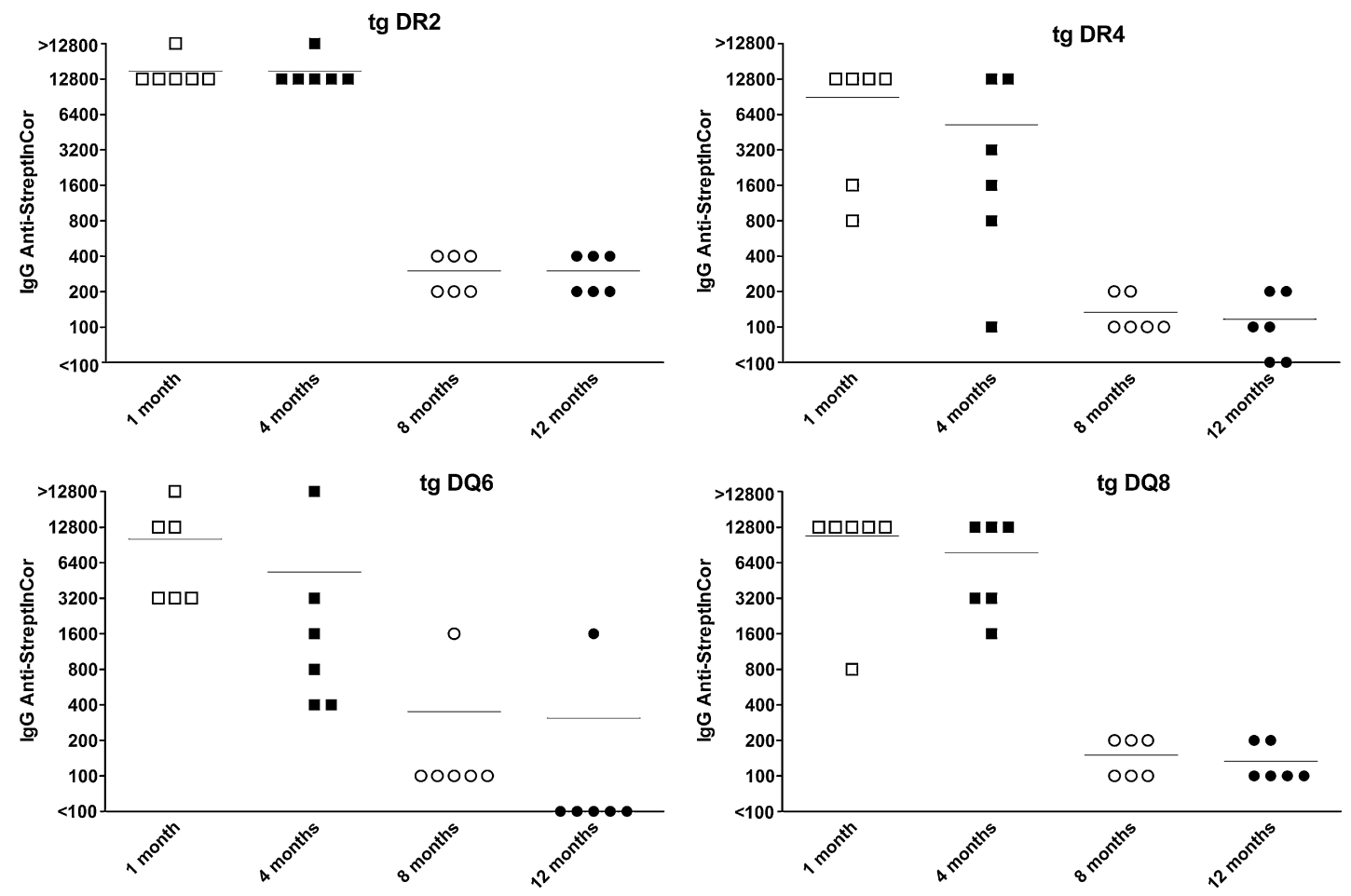

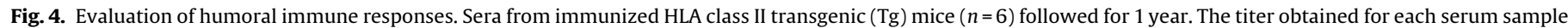
at $1(\square), 4(\square), 8(\bigcirc)$, and 12 months $(\bullet)$. Titers less than 100 are represented as negative values.

Table 1

Immune recognition of overlapping M protein C-terminal peptides.

\begin{tabular}{|c|c|c|c|c|}
\hline \multirow[t]{2}{*}{ Overlapping peptides sequences ( 20 aa residues) } & \multicolumn{4}{|c|}{ Transgenic mice bearing HLA class II alleles humoral immune response (IgG) } \\
\hline & DR2 & DR4 & DQ6 & DQ8 \\
\hline KGLRRDLDASREAKKQLEAE & $6^{+} / 6$ & $5^{+} / 6$ & $2^{+} / 6$ & $5^{+} / 6$ \\
\hline KGLRRDLDASREAKKQVEKA & $5^{+} / 6$ & $5^{+} / 6$ & $3^{+} / 6$ & $4^{+} / 6$ \\
\hline GLRRDLDASREAKKQVEKAL & $5^{+} / 6$ & $5^{+} / 6$ & $2^{+} / 6$ & $3^{+} / 6$ \\
\hline LDASREAKKQLEAEQQKLEE & $4^{+} / 6$ & $5^{+} / 6$ & $3^{+} / 6$ & $6^{+} / 6$ \\
\hline KLEEQNKISEASRKGLRRDL & $5^{+} / 6$ & $4^{+} / 6$ & $3^{+} / 6$ & $5^{+} / 6$ \\
\hline KISEASRKGLRRDLDASREA & $5^{+} / 6$ & $2^{+} / 6$ & $2^{+} / 6$ & $3^{+} / 6$ \\
\hline SEASRKGLRRDLDASREAKK & $5^{+} / 6$ & $4^{+} / 6$ & $3^{+} / 6$ & $5^{+} / 6$ \\
\hline ASRKGLRRDLDASREAKKQV & $4^{+} / 6$ & $4^{+} / 6$ & $1^{+} / 6$ & $2^{+} / 6$ \\
\hline
\end{tabular}

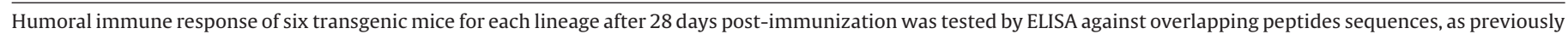
described by us [21,22]. Positive immune response was considered when antibodies titles were $\geq 1: 100$ and $\leq 1: 3200$.

(APCs) as previously described [22]. Our results were similar to those observed in humans. Both, HLA-DR and -DQ Tg-mice recognized most of the peptides (Table 1 ). It was interesting to note that the immune response was more frequent in mice bearing HLADR molecules than in those bearing HLA-DQ, the second molecule (Table 1). Titles of antibodies varied from 1:100 to 1:3200 (data not shown).

\subsection{StreptInCor does not induce deleterious reactions}

The safety of the vaccine epitope was evaluated by analyzing the histopathology of several organs in mice 1 year after immunization (Fig. 4). No autoimmune or pathological reactions were observed in the heart or other organs (Fig. 5) because of the immunization with StreptInCor and alum. However, some vaccinated transgenic mice (10 out of 24 ) and those that only received aluminum hydroxide in saline (9 out of 24) developed defective hematopoiesis, hepatic steatosis, or presented mononuclear infiltration (Table 2).

\section{Discussion}

We developed a vaccine epitope (StreptInCor) composed of 55 amino acid residues of the C-terminal portion of the $\mathrm{M}$ protein that encompasses both $\mathrm{T}$ and B cell-protective epitopes [21]. The structural, chemical, and biological properties of this peptide were evaluated, and we show that StreptInCor is a very stable molecule, which is an important property for a vaccine candidate. Additionally, our previous results show that humans, bearing different HLA class II molecules recognize StreptInCor, which demonstrates the universal character of this vaccine [22]. It is interesting to note that both healthy individuals and rheumatic fever and rheumatic heart disease patients were able to respond to StreptInCor peptide. No cross reactivity against human myocardium and valve proteins was observed, indicating that StreptInCor is immunogenic and safe [21].

The role of HLA class II molecules in the antigen presentation and that this vaccine should avoid autoimmune reactions, were considered in the present work; therefore, we evaluated the capacity of HLA class II transgenic mice to recognize the vaccine epitope combined with aluminum hydroxide adjuvant while not inducing autoimmune reactions. This adjuvant has been used in 

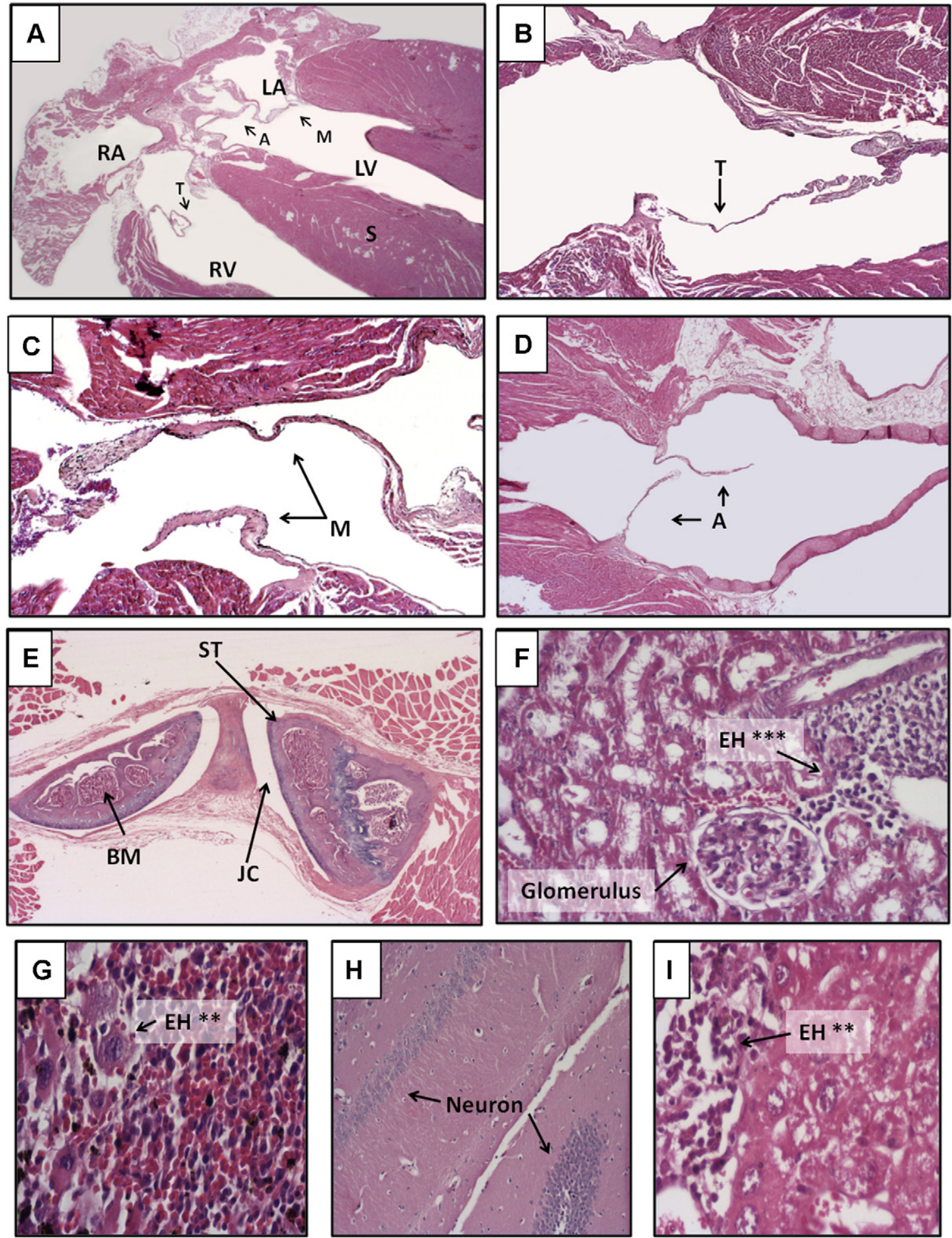

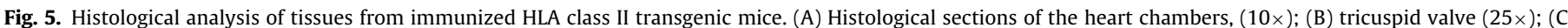

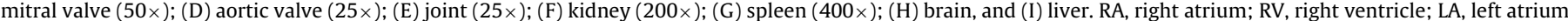

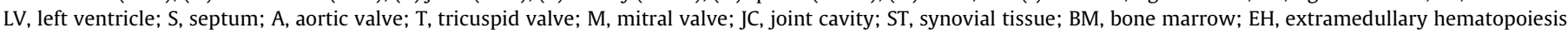
${ }^{* *}$ moderate ${ }^{* * *}$ intense. H\&E, hematoxylin and eosin stain.

veterinarian and human vaccines since 1930 and causes very little systemic toxicity [31].

The presence of the HLA class II transgene will affect the immune response in the whole mouse since thymic selection will interfere with the interactions between $T$ lymphocytes and antigen presenting cells and with the activation of B lymphocytes in the periphery.
The biological properties of HLA class II molecules, together with testing their role in a transgenic mice model, are useful for new vaccine studies. Recently, our group showed that the HLA class II transgenic mice are able to respond to multi-epitopic vaccines against HIV by inducing proliferation of both CD4+ and CD8+ T lymphocytes and the production of IFN $\gamma$ [32]. 
Table 2

Histopathological analysis.

\begin{tabular}{|c|c|c|c|c|c|c|c|}
\hline HLA class II tg mice & Immunization & Gender & Number & Kidney & Spleen & Liver & Bone marrow (\% cells) \\
\hline \multirow[t]{6}{*}{ DR2 } & StreptInCor + Alum & $\mathrm{F}$ & 6 & $2 \mathrm{EH}^{\mathrm{a}}$ & & $1 \mathrm{EH}^{\mathrm{b}}$ & \\
\hline & & & & & & $1 \mathrm{St}^{\mathrm{a}}$ & $98-100$ \\
\hline & & & & & & $1 \mathrm{St}^{\mathrm{c}}$ & \\
\hline & Saline + Alum & $\mathrm{F}$ & 6 & $1 \mathrm{EH}^{\mathrm{a}}$ & & $1 \mathrm{St}^{\mathrm{a}}$ & $90-100$ \\
\hline & & & & & & $1 \mathrm{St}^{\mathrm{b}}$ & \\
\hline & & & & & & $1 \mathrm{St}^{\mathrm{c}}$ & \\
\hline \multirow[t]{3}{*}{ DR4 } & StreptInCor + Alum & $\mathrm{F}$ & 6 & $1 \mathrm{MNL}$ & & $2 \mathrm{EH}^{\mathrm{a}}$ & $90-100$ \\
\hline & Saline + Alum & M & 2 & & $1 \mathrm{EH}^{\mathrm{b}}$ & $2 \mathrm{EH}^{\mathrm{b}}$ & $90-100$ \\
\hline & & $\mathrm{F}$ & 4 & $1 \mathrm{MNL}$ & $3 \mathrm{EH}^{\mathrm{a}}$ & $2 \mathrm{EH}^{\mathrm{a}}$ & \\
\hline \multirow[t]{3}{*}{ DQ6 } & StreptInCor + Alum & M & 5 & & & $1 \mathrm{EH}^{\mathrm{b}}$ & $98-100$ \\
\hline & & $\mathrm{F}$ & 1 & & & & \\
\hline & Saline + Alum & $\mathrm{F}$ & 4 & & $2 \mathrm{EH}^{\mathrm{a}}$ & $1 \mathrm{EH}^{\mathrm{b}}$ & $98-100$ \\
\hline \multirow[t]{5}{*}{ DQ8 } & StreptInCor + Alum & M & 6 & & $1 \mathrm{EH}^{\mathrm{a}}$ & $3 \mathrm{EH}^{\mathrm{a}}$ & 100 \\
\hline & & & & & & $2 \mathrm{EH}^{\mathrm{c}}$ & \\
\hline & Saline + Alum & M & 4 & & $1 \mathrm{EH}^{\mathrm{a}}$ & $1 \mathrm{EH}^{\mathrm{a}}$ & 100 \\
\hline & & & & & $1 \mathrm{EH}^{\mathrm{b}}$ & $1 \mathrm{EH}^{\mathrm{b}}$ & \\
\hline & & & & & $1 \mathrm{EH}^{\mathrm{c}}$ & $1 \mathrm{EH}^{\mathrm{c}}$ & \\
\hline
\end{tabular}

tg - transgenic mice; MNL - mononuclear infiltration; EH - extramedullary hematopoiesis; St - steatosis

a Mild.

b Moderate.

c Intense.

The data presented here show that all HLA class II transgenic mice (DR2, DR4, DQ6 and DQ8) immunized with StreptInCor plus aluminum hydroxide were able to produce specific IgG antibodies that also recognize the vaccine epitope in the context of a heterologous M protein. According to our previous data on human sera and peripheral blood cells [22], the results presented here also indicated that antigen presenting cells of HLA class II transgenic mice bearing DR2, DR4, DQ6 and DQ8 molecules were able to present several peptides encompassed by StreptInCor vaccine epitope, probably via the TCR with activation of both T and B lymphocytes. In addition, it is interesting to note that transgenic mice bearing the HLA-DR molecules were more responsive than those bearing the second HLA class II molecules (DQ6 or DQ8). In agreement with these data the IgG specific responses in DR2 and DR4 transgenic mice were slightly better than in mice bearing DQ6 and DQ8 molecules. Although some mice became nonresponsive a year after the immunization, the immune responses to StreptInCor were maintained for up to a year. These results also indicated that the vaccine epitope is able to induce a long period of specific immune responses, with IgG1 predominance due to the effects of the adjuvant. The balance between humoral and cellular immune responses induced by adjuvant formulations can be addressed through the isotype profile of the vaccine-specific IgG1 and IgG2a antibodies produced. The IgG1 isotype switch is dependent of IL-4 production in opposite to isotype IgG2a, which is IFN- $\gamma$ dependent. We observed a huge predominance of specific IgG1 when compared to IgG2a and also to IgG3, another IFN- $\gamma$ dependent isotype. It is interesting to note that some IgG2b, a TGF- $\beta$-depending switch, was seen in some animals from all groups studied (DR2, DR4, DQ6 and DQ8). Finally, aluminum adjuvants are responsible for Th2 polarization, resulting in increased humoral immunity, mediated by production of IgG1 isotype.

Considering pharyngitis is among the most common S. pyogenes infections, the induction of mucosal immune responses, mainly by IgA secretions, is attractive. Accordingly, other adjuvants are being assayed to obtain both systemic and mucosal immune responses. One of the major challenges of producing a vaccine against to $S$. pyogenes is to not induce autoimmune responses and diseases such as RF and RHD. Although we know the mechanisms that lead the disease in humans [13], there have been no ideal in vivo models of the disease, except for in the Lewis rat [33], until our current study.

As myosin is a putative auto-antigen involved in RHD development [33-39], we used both human myocardium-derived proteins and porcine cardiac myosin to evaluate the presence of crossreactive antibodies that could be triggered by the immunizations. No specific cross reactivity against heart proteins was observed indicating that StreptInCor did not induce autoimmune reactions.

Myosin heavy chains have been categorized into several classes based on comparisons and phylogenetic analysis of the conserved regions [40-42]. It is interesting to note that the coiled coil region differs among the species studied however global results suggested a common coevolution of myosin head, neck and tail domains [40-42]. So, the fact that we used both porcine myosin and human cardiac protein extract, in which cardiac myosin is the major protein, strongly indicated that StreptInCor vaccine epitope is unable of inducing autoimmune reactions.

Although the histopathology of mice assessed a year after the last immunization showed some alterations, such as extramedullary hematopoiesis, liver steatosis, and infiltration of mononuclear cells in the kidney, these observations were also observed in the control animals. This finding suggests that these features are not due to the immunization with the vaccine epitope and are most likely due to aging of the mice. In support of this finding, the analysis of the heart tissue, with a special focus on the valves, and the other organs after 1 year did not display any specific RF lesions.

Despite these promising results, humans are the only hosts for GAS. Although several studies have been conducted to find a suitable animal model, there is no suitable animal model that can desiccate the autoimmune process of RF and RHD.

\section{Conclusions}

All the results presented here indicate that the StreptInCor vaccine epitope induces a robust and long lasting immune response in transgenic mice and not induces autoimmune reactions and can be considered a promising vaccine candidate to prevent RF.

\section{Acknowledgments}

We acknowledge Prof. Dr. Chella S. David from Department of Immunology, Mayo Clinic and Julie Hanson, Supervisor of Immunogenetics Mouse Colony from Mayo Clinic, Rochester, USA for provided the transgenic mice used in this study and Prof Patrick Cleary, University of Minnesota Medical School, MN, USA for provided the M1 recombinant clone). This work was supported by 
grants from "Fundação de Amparo à Pesquisa do Estado de Sao Paulo (FAPESP)" and "Conselho Nacional de Desenvolvimento Científico e Tecnológico (CNPq)".

\section{References}

[1] Carapetis JR, Steer AC, Mulholland EK, Weber M. The global burden of group A streptococcal diseases. Lancet Infect Dis 2005;5(November (11)):685-94.

[2] Cardiologia SBd. Brazilian guidelines for the diagnosis, treatment and prevention of rheumatic fever. Arq Bras Cardiol 2009;93(September (3 Suppl 4)):3-18.

[3] Fischetti VA. Streptococcal M protein. Sci Am 1991;264(June (6)):58-65

[4] Guilherme L, Kalil J, Cunningham M. Molecular mimicry in the autoimmune pathogenesis of rheumatic heart disease. Autoimmunity 2006;39(February (1)):31-9.

[5] Martins TB, Hoffman JL, Augustine NH, Phansalkar AR, Fischetti VA, Zabriskie JB, et al. Comprehensive analysis of antibody responses to streptococcal and tissue antigens in patients with acute rheumatic fever. Int Immunol 2008;20(March (3)):445-52.

[6] Kraus W, Ohyama K, Snyder DS, Beachey EH. Autoimmune sequence of streptococcal M protein shared with the intermediate filament protein, vimentin. J Exp Med 1989;169(February (2)):481-92.

[7] Kraus W, Seyer JM, Beachey EH. Vimentin-cross-reactive epitope of type 12 streptococcal M protein. Infect Immun 1989;57(August (8)):2457-61.

[8] Sargent SJ, Beachey EH, Corbett CE, Dale JB. Sequence of protective epitopes of streptococcal M proteins shared with cardiac sarcolemmal membranes. J Immunol 1987;139(August (4)):1285-90.

[9] Jones KF, Khan SA, Erickson BW, Hollingshead SK, Scott JR, Fischetti VA. Immunochemical localization and amino acid sequences of crossreactive epitopes within the group A streptococcal M6 protein. J Exp Med 1986;164(October (4)):1226-38.

[10] Dale JB, Beachey EH. Sequence of myosin-crossreactive epitopes of streptococcal M protein. J Exp Med 1986;164(November (5)):1785-90.

[11] Kaplan MH. Immunologic relationship of group A streptococcal strains and human heart tissue. Possible significance for the pathogenesis of rheumatic fever. Am Heart J 1963;65(March):426-7.

[12] Guilherme L, Cury P, Demarchi LM, Coelho V, Abel L, Lopez AP, et al. Rheumatic heart disease: proinflammatory cytokines play a role in the progression and maintenance of valvular lesions. Am J Pathol 2004;165(November (5)):1583-91.

[13] Cunningham MW. Pathogenesis of group A streptococcal infections. Clin Microbiol Rev 2000;13(July (3)):470-511.

[14] Guilherme L, Faé KC, Oshiro SE, Tanaka AC, Pomerantzeff PM, Kalil J. T cell response in rheumatic fever: crossreactivity between streptococcal M protein peptides and heart tissue proteins. Curr Protein Pept Sci 2007;8(February (1)):39-44.

[15] Guilherme L, Köhler KF, Kalil J. Rheumatic heart disease: mediation by complex immune events. Adv Clin Chem 2011;53:31-50.

[16] Shulman ST, Tanz RR, Dale JB, Beall B, Kabat W, Kabat K, et al. Seven-year surveillance of north american pediatric group a streptococcal pharyngitis isolates. Clin Infect Dis 2009;49(July (1)):78-84.

[17] Kotloff KL, Dale JB. Progress in group A streptococcal vaccine development. Pediatr Infect Dis J 2004;23(August (8)):765-6.

[18] Kotloff KL, Corretti M, Palmer K, Campbell JD, Reddish MA, Hu MC, et al. Safety and immunogenicity of a recombinant multivalent group a streptococcal vaccine in healthy adults: phase 1 trial. JAMA 2004;292(August (6)):709-15.

[19] Hu MC, Walls MA, Stroop SD, Reddish MA, Beall B, Dale JB. Immunogenicity of a 26-valent group A streptococcal vaccine. Infect Immun 2002;70(April (4)):2171-7.

[20] Olive C, Schulze K, Sun HK, Ebensen T, Horváth A, Toth I, et al. Enhanced protection against Streptococcus pyogenes infection by intranasal vaccination with a dual antigen component $\mathrm{M}$ protein/SfbI lipid core peptide vaccine formulation. Vaccine 2007;25(February (10)):1789-97.

[21] Guilherme L, Faé KC, Higa F, Chaves L, Oshiro SE, Freschi de Barros $S$, et al. Towards a vaccine against rheumatic fever. Clin Dev Immunol 2006;13(June-December (2-4)):125-32.
[22] Guilherme L, Alba MP, Ferreira FM, Oshiro SE, Higa F, Patarroyo ME, et al. Antigroup A streptococcal vaccine epitope: structure, stability, and its ability to interact with HLA class II molecules. J Biol Chem 2011;286(March (9)):6989-98.

[23] Madsen L, Labrecque N, Engberg J, Dierich A, Svejgaard A, Benoist C, et al. Mice lacking all conventional MHC class II genes. Proc Natl Acad Sci USA 1999;96(August (18)):10338-43.

[24] Pan S, Trejo T, Hansen J, Smart M, David CS. HLA-DR4 (DRB1*0401) transgenic mice expressing an altered CD4-binding site: specificity and magnitude of DR4restricted T cell response. J Immunol 1998;161(September (6)):2925-9.

[25] Gonzalez-Gay MA, Zanelli E, Khare SD, Krco CJ, Zhou P, Inoko H, et al. Human leukocyte antigen-DRB1*1502 (DR2Dw12) transgene reduces incidence and severity of arthritis in mice. Hum Immunol 1996;50(September (1)):54-60.

[26] Bradley DS, Nabozny GH, Cheng S, Zhou P, Griffiths MM, Luthra HS et al. HLA-DQB1 polymorphism determines incidence, onset, and severity of collagen-induced arthritis in transgenic mice, Implications in human rheumatoid arthritis. J Clin Invest 1997;100(November (9)):2227-34.

[27] Nabozny GH, Baisch JM, Cheng S, Cosgrove D, Griffiths MM, Luthra HS, et al. HLA-DQ8 transgenic mice are highly susceptible to collagen-induced arthritis: a novel model for human polyarthritis. J Exp Med 1996;183(January (1)):27-37.

[28] Chapoval SP, Neeno T, Krco CJ, Marietta EV, Harders J, David CS. HLA-DQ6 and HLA-DQ8 transgenic mice respond to ragweed allergens and recognize a distinct set of epitopes on short and giant ragweed group 5 antigens. J Immunol 1998;161(August (4)):2032-7.

[29] Laemmli UK. Cleavage of structural proteins during the assembly of the head of bacteriophage T4. Nature 1970;227(August (5259)):680-5.

[30] Towbin H, Staehelin T, Gordon J. Electrophoretic transfer of proteins from polyacrylamide gels to nitrocellulose sheets: procedure and some applications. Proc Natl Acad Sci USA 1979;76(September (9)):4350-4.

[31] Singh M, O'Hagan D. Advances in vaccine adjuvants. Nat Biotechnol 1999;17(November (11)):1075-81.

[32] Ribeiro SP, Rosa DS, Fonseca SG, Mairena EC, Postól E, Oliveira SC, et al. A vaccine encoding conserved promiscuous HIV CD4 epitopes induces broad T cell responses in mice transgenic to multiple common HLA class II molecules. PLoS One 2010;5(6):e11072.

[33] Galvin JE, Hemric ME, Kosanke SD, Factor SM, Quinn A, Cunningham MW. Induction of myocarditis and valvulitis in lewis rats by different epitopes of cardiac myosin and its implications in rheumatic carditis. Am J Pathol 2002;160(January (1)):297-306.

[34] Faé KC, da Silva DD, Oshiro SE, Tanaka AC, Pomerantzeff PM, Douay C, et al. Mimicry in recognition of cardiac myosin peptides by heart-intralesional T cell clones from rheumatic heart disease. J Immunol 2006;176(May (9)):5662-70.

[35] Lymbury RS, Olive C, Powell KA, Good MF, Hirst RG, LaBrooy JT, et al. Induction of autoimmune valvulitis in Lewis rats following immunization with peptides from the conserved region of group A streptococcal M protein. J Autoimmun 2003;20(May (3)):211-7.

[36] Gorton D, Govan B, Olive C, Ketheesan N. B- and T-cell responses in group a streptococcus M-protein- or Peptide-induced experimental carditis. Infect Immun 2009;77(May (5)):2177-83.

[37] Gorton D, Blyth S, Gorton JG, Govan B, Ketheesan N. An alternative technique for the induction of autoimmune valvulitis in a rat model of rheumatic heart disease. J Immunol Methods 2010;355(April (1-2)):80-5.

[38] Cunningham MW. T cell mimicry in inflammatory heart disease. Mol Immunol 2004;40(February (14-15)):1121-7.

[39] Ellis NM, Li Y, Hildebrand W, Fischetti VA, Cunningham MW. T cell mimicry and epitope specificity of cross-reactive T cell clones from rheumatic heart disease. J Immunol 2005;175(October (8)):5448-56.

[40] Goodson HV, Spudich JA. Molecular evolution of the myosin family: Relationships derived from comparisons of amino acid sequences. Proc Natl Acad Sci USA 1993;January (90):659-63.

[41] Alpert NR, Brosseau C, Federico A, Krenz M, Robbins J, Warshaw DM. Molecular mechanics of mouse cardiac myosin isoforms. Am J Physiol Heart Circ Physiol 2002;283(June):H1446-54.

[42] Foth BJ, Goedecke MC, Soldati D. New insights into myosin evolution and classification. Proc Natl Acad Sci USA 2006;103(March (10)):3681-6. 